\title{
CONTRIBUTIONS TO THE HYDROLOGY OF THE UNITED STATES, 1928
}

\author{
N. C. Grover, Chief Hydraulic Engineer \\ GEOLOGY OF RESERVOIR AND DAM SITES
}

By KIrK Bryan

ENGINEERING GEOLOGY

All engineering structures constitute a load on the earth's crust. If this crust were everywhere of the same character and strength the design of such structures could be much simplified, but the heterogeneity of the materials of the earth's crust and the complexity of their arrangement are notorious, and these geologic conditions enter into most engineering problems. Certain structures, such as bridge piers, dams, tunnels, and heavy buildings, require both for design and construction unusually precise knowledge of the strength, attitude, and water-bearing character of the local rocks. Other structures, such as channel-training works on rivers or coast-protection and harbor works, being intended to guide or restrain natural forces, require an equally precise knowledge of the geologic changes that constantly take place on the earth's surface. Moreover, unusual earth movements and the resulting tremors or earthquakes often endanger the works of man, and in certain localities should be amply guarded against in the design of engineering structures.

It has been well said that the task of the engineer is "to overcome by art the difficulties of Nature." Much of his effort is used in the contest with space, time, and weather or in the ingenious harnessing of sources of power, but in the great construction enterprises already named he contends also with the materials of the earth and the forces that operate on them and thus must solve problems within the field of geology. Many engineers and many great construction enterprises have contributed to geologic knowledge. Whenever an 
engineer digs a hole for a foundation he is investigating the local geology, and when he erects the simplest building he performs an experiment on the strength of the materials of the earth's crust. Within the limits of his test, and in ordinary construction the limits are narrow, the engineer has learned all the geology that it is necessary for him to know. However, on large undertakings simple procedure and rule of thumb methods derived from such simple tests are inadequate, and elaborate investigations by means of pits, drill holes, loading tests, and so on, are resorted to in order to obtain the necessary information for intelligent design. In an increasing number of undertakings geologists are being called in to give the benefit of their specialized knowledge and of their ability to reduce the number of tests required by locating them in truly significant places. They are needed also to interpret correctly the results obtained.

The responsibilities of a geologist so chosen are very great. However well he may know his own subject, he is handicapped in such duty in proportion as he is ignorant of engineering construction. Little has been published on the application of geology to engineering problems. Most books bearing the title "Engineering geology" are simply college textbooks designed to give engineering students those parts of geology that are most valuable and interesting to them. Exceptions are the very interesting though now somewhat antiquated book by Penning, ${ }^{1}$ a recent somewhat sketchy book by Fox, ${ }^{2}$ the valuable treatise by De Launay, ${ }^{3}$ the third edition of Ries and Watson's textbook, ${ }^{4}$ and the highly individual book by Kranz. ${ }^{4 a}$

A paper by Lapworth ${ }^{5}$ contains much wise observation of geologic conditions in the foundations of dams illustrated with detailed cross sections, but it must be read with the qualification that it deals with British dams constructed in the light of British opinion in favor of deep cut-off walls, usually of puddled clay.

Interesting information will be found in an essay by Dumas ${ }^{6}$ and, on certain phases of reservoir problems, in a book by Collet. ${ }^{7}$

The use of geology in engineering is advocated in a number of articles and addresses, but they contain very little information on the

${ }^{1}$ Penning, W. H., Engineering geology, 164 pp., London, 1880.

2 Fox, Cyril, Civil engineering geology, London, 1923.

${ }^{3}$ De Launay, $\mathbf{L}$., Traité de géologie et de minéralogie appliquuées à l'art de l'ingénieur, 416 pp., 288 figs., Paris, 1922.

${ }^{4}$ Ries, Heinrich, and Watson, T. L., Engineering geology, vii+708 pp., New York, 1925.

4a Kranz, W., Die Geologie im Ingenieur-Baufach, 425 pp., 7 pls., 53 fig.s., Stuttgart, 1927.

s Lapworth, Herbert, The geology of dam trenches : Inst. Water Eng. (London) Trans., vol. 16, pp. 25-51; discussion, pp. 51-66, 1911. Reprinted with 1 fig. only, Eng. News, vol. 67, pp. $476-480,1912$.

${ }^{6}$ Dumas, A., Etude théorique et pratique sur les barrages-réservoirs (extrait du Journal de gênie civil), 164 pp., 1896.

${ }^{7}$ Collet, L. W., Les lacs, etc., 320 pp., Paris, 1925. 
principles involved. Only a few reports on the geology of engineering projects written as a practical guide to construction have been published, and some of these are hidden in engineering documents or in serials not easy of access. In the appended bibliography the papers bearing on the geology of dams, reservoirs, and tunnels in the United States that have come to my attention are given, and brief notes on their scope have been added. A few of the articles were written by engineers, but these contain highly specialized or very detailed geologic information with discussions of the application of this information as to the problems considered. The papers by the late W. O. Crosby and those by Charles P. Berkey are of the highest excellence, and the serious student of engineering geology should digest them thoroughly.

The present paper is offered in the hope that it will be helpful in promoting the application of geology to many irrigation and other engineering projects and that it may guide the geologist charged with the duty of investigating such projects in the presentation of his material.

The infinite variety of possible geologic conditions makes it impracticable to anticipate the type of work that will be necessary for any project to which a geologist may be assigned, but some principles of the application of geology are more or less common to all investigations. A short statement of such of these principles as have been learned in the course of a number of investigations is included herein. The personal element in such work is of large importance, and some remarks on the relation of geologists and engineers have been added.

\section{RESERVOIR SITES}

\section{GENERAL REQUISITES}

The requisites of a reservoir site are many and exacting; the chief of these are, in a form modified from the statement of Lippincott, ${ }^{8}$ (1) a tight basin of ample size; (2) a narrow outlet requiring a relatively small and economical dam, with foundations able to sustain the dam; (3) opportunity for building a safe and ample spillway to dispose of surplus water; (4) available materials of which to construct the dam; (5) assurance that the basin will not fill with mud and sand carried in the water in too short a time; (6) ample and available water supply; (7) use for the stored water or other adequate reason to justify the cost.

It is obvious that a geologist is concerned only with the first five requisites. That the basin must be ample in size is self-evident, and

${ }^{8}$ Lippincott, J. B., Storage of water on Kings River, Calif.: U. S. Geol. Survey WaterSupply Paper 58, p. 25, 1902. 
the size is determined by ordinary engineering methods; but the question of its water-tightness can not be answered simply by yes or no, for in spite of leakage some reservoirs are worth their cost. The geologist, therefore, must give this question not only a qualitative but also a quantitative determination to realize his greatest usefulness. He must consider also whether leakage will progressively enlarge the openings and thereby increase and whether it will destroy the stability of the ground.

The size and therefore the cost of the dam required are largely determined by a survey of the site, but the character of the dam and its details are, in many localities, governed by the geology, especially the capacity of the foundations and abutments to transmit water or to sustain weight. These problems require the closest cooperation of geologist and engineer, as the number of engineering devices to overcome natural difficulties continually increases.

Materials of good quality locally available decrease costs, and the geologist should act as a scout to locate and evaluate the rock, gravel, sand, and clay that occur near by. Such qualitative studies are usually inadequate for a final decision as to the usefulness of these materials, and detailed examinations by test pits with laboratory study of samples may be necessary, but these investigations fall within the ordinary field of engineering and do not necessarily require the attention of the geologist, although he may be able to give helpful advice during their progress.

The detritus carried by a stream will lodge in all reservoirs formed by damming a stream valley. On muddy streams the quantity of this material, usually called "silt," may be very large and the reservoir may be filled or "silted" in so short a time as to make its construction inadvisable. Measurement of the "silt" content of a stream $^{9}$ falls in the field of engineering, but on preliminary surveys and estimates the geologist may give useful advice and counsel, because the quantity of detritus carried by a stream is a function of the distribution and area of the rocks of the drainage basin. Several examples are described by Collet. ${ }^{10}$

\section{HYDROLOGY OF A RESERVOIR}

When a reservoir is filled water escapes from the basin to the adjacent ground. Even concrete-lined reservoirs leak appreciably, and in consequence of these leaks the foundations of a few reservoirs have been undermined with disastrous results. ${ }^{11}$ Large reservoirs

\footnotetext{
- Bryan, Kirk, Silting of reservoirs, studies by engineers [with bibliography] : Nat. Res. Council Researches in Sedimentation in 1925-26, mimeographed, pp. 88-94, 1926.

${ }^{10}$ Collet, L. W., Les lacs, pp. 198-274, Paris, 1925.

I1 Purdue, A. H., Geology and engineering: Resources of Tennessee, vol. 3, pp. 105-109, 1913.
} 
are, of course, unlined, for the cost of lining them is prohibitive. Therefore, unless the leakage to the ground is resisted by natural conditions or is relatively so small as to be of little consequence, the reservoị is a failure. As the leakage must be resisted by the characteristics of the ground, study of a site for a reservoir is a geologic and more particularly a ground-water problem. To solve this problem completely the position and movements of the ground water under natural conditions must be determined, and the effect of filling the basin in producing a new régime in the ground water of the area-by the movement of water from the basin outward to the ground-must be anticipated.
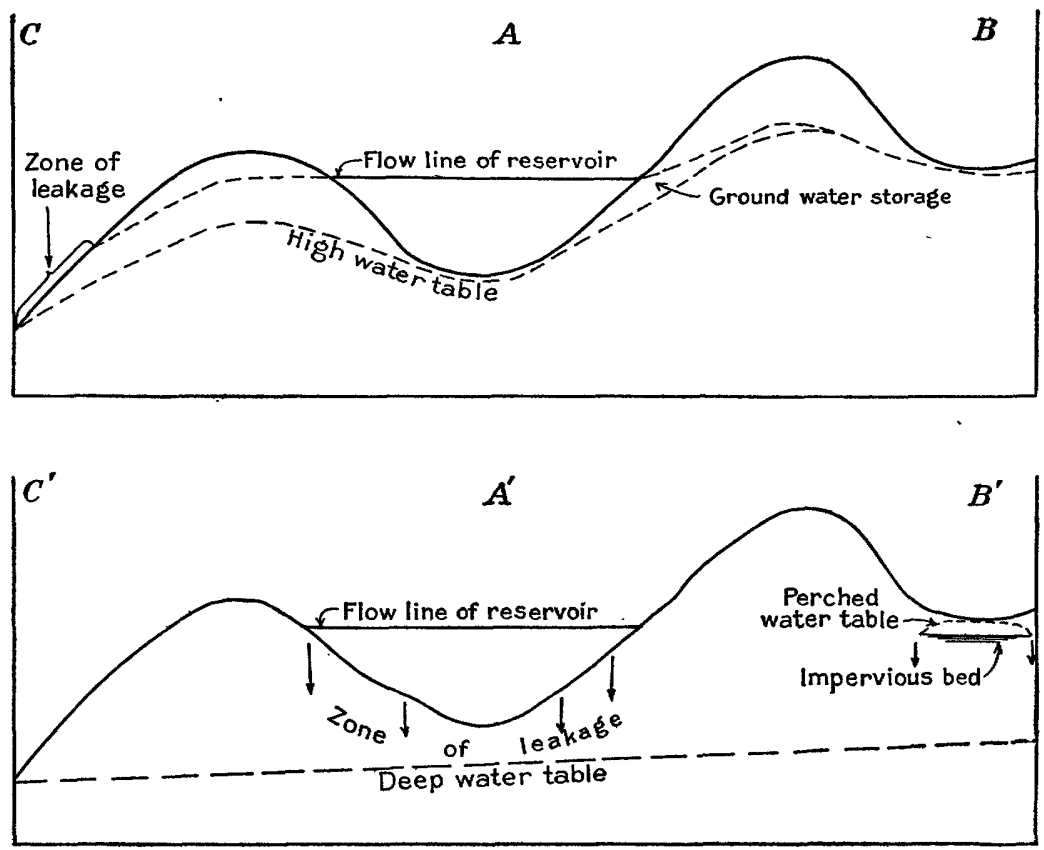

Figurp 1.-Diagram showing the relation of reservoirs to the water table

\section{RESERVOIRS IN AREAS OF HIGH WATER TABLE}

Ordinarily the soils and rocks are saturated with water below a certain depth. The top of this saturated zone is known as the water table. It lies deep beneath hills and comes to the surface at swamps, ponds, and streams. Thus in a general way, under what may be considered normal conditions, the water table has a form approximating the surface topography. In a valley it slopes downstream and from both sides toward the middle of the valley, as suggested in Figure 1, $A$. Such a form is due to the resistance to flow afforded by friction in the interstices of the ground. The gradient of the 
water table at any place is a function of the size and number of the interstices or openings in the ground and the quantity of water. A steep water table thus indicates tight ground with small interstices or very large quantities of water; conversely, a flat water table indicates large openings in the rocks or very small quantities of water.

If a valley is blocked by a dam, water from the resulting lake will sink into the ground until it meets the inclosing water table. Thereafter a new grade of the water table will be established. If the altitude of the reservoir is below the ground-water divide not only will there be no loss by seepage from the reservoir but there will be an inflow of ground water into the reservoir and an underground storage between the old position and the new position of the water table. The volume of ground that will be newly saturated depends on the water level in the reservoir and on the slope of the water table. The value of this ground-water storage depends on the percentage of pore space and also on the rate at which water will flow in or out of the ground as the water level in the reservoir changes.

In the foregoing discussion nothing has been said about leakage at the dam site. It is obvious, however, that there will exist in the abutments of the dam a high gradient between the water in the reservoir and the level of the ground water just downstream. As this is the place where the new water level is highest with respect to the original level, conditions are here most critical. The abutments of the dam must be practically tight, or serious leakage will occur. As the character of the abutments enters into the problem of building the dam, however, discussion of that topic will be deferred to a later paragraph.

In general, little difficulty is experienced with reservoirs built in areas of high water table when the reservoir occupies a stream valley and the stream is fed by ground water. Under conditions shown at point $C$, Figure 1, leakage is possible from overtopping the groundwater divide at a low point, but it will be moderate if the material of the ridge is fine grained. Where part of the inclosing rim of the reservoir consists of open-textured material; such as basalt, cavernous limestone, or an accumulation of glacial boulders, the ground-water divide is always low also, and thus the low position of the water table, if determined, would speak for caution, but proof of the presence of these open-textured materials makes it certain that large leakage will result. It should be noted that leakage through gypsum or rock salt and to a less extent through limestone will increase by reason of solution of the rock and the removal of débris from caves already formed, but leakage through basalt will be constant or only slightly increased. Leakage through boulders or gravel may, by the 
removal of sand and similar fine material from the interstices, induce slumping and landslides, with serious consequences. If the openings through which the water leaves the reservoir are not too large, leakage may gradually decrease by reason of the deposition in them of sediment that falls to the floor of the reservoir. The quantity of silt carried by the streams that feed the reservoir and many other factors enter into this contingency. In Bijápur Collectorate, India, the Muchkundi Tank, ${ }^{12}$ formed by a masonry dam on schistose rocks, was sealed and made tight after 12 years of silting. In Yorkshire, England, ${ }^{13}$ a reservoir formed by a dam 80 feet high leaked 440,000 gallons daily through fissures in the rock of the foundation. After two years of use the fissures were sealed by the deposit of silt and leakage ceased.

A masonry dam ${ }^{14}$ across Cedar River, a tributary of Snoqualmie River in Washington, was constructed with its south (left) end resting on "seamy" rock. The north (right) end rested in glacial material. Some leakage through the rock at the south end and around the north end of the dam took place, but large and disastrous leakage occurred through the glacial material that formed the ridge between the two rivers. When the water in the reservoir stood at an altitude of 1,555 feet, springs broke out in Snoqualmie Valley at an altitude of 990 feet. The hydrostatic head was 565 feet, and the distance 6,500 feet, making a gradient of 1 to 11 . The emergence of this leakage in Snoqualmie Valley caused slumping of the hillside. The total loss of water was $30,000,000$ gallons daily (46.5 second-feet), and since 1914 the reservoir has not been allowed to fill. On account of continuous litigation full descriptions of the materials involved and of tests before and after construction are not available. The glacial materials of the ridge were, however, obviously so coarse grained and porous that it was evident before construction to both geologists and engineers, as set forth by Fowler, that the ridge could not resist the movement of water from the reservoir on a gradient of 1 to 11 .

At the Santa Maria Reservoir, in Colorado, leakage takes p.ace through 2 miles of landslide material at the south end of the water body. At Mosca Reservoir, ${ }^{15}$ in the same State, leakage through shattered volcanic rock and morainal material has occurred. In the morainal leak the water passed through 1,500 feet of sand and gravel and produced a washout, leaving a ravine 20 feet deep.

\footnotetext{
${ }^{12}$ Strange, W. L., Reservoirs with high earthen dams in western India : Inst. Civil Eng. London Proc., vol. 132, p. 137, 1898.

13 Hill, G. M., discussion of Strange's paper : Idem, p. 208.

14 Fowler, C. E., Leakage from Cedar Lake Reservoir, Seattle water supply : Eng. News, vol. 73, pp. 112-115, 1915.

${ }^{15}$ Atwood, W. W., Relations of landslides and glacial deposits to reservoir sites in the San Juan Mountains, Colo.: U. S. Geol. Survey Bull. 685, pp. 23-33, 1918.
} 


\section{RESERVOIRS IN AREAS OF DEEP WATER TABLE}

The water table lies deep under large areas only where the rocks are notably porous and the openings are large. In such rocks water flows freely at low gradients comparable to the gradients of surface streams. In tighter rocks the gradient of the water table is higher, and only small areas may have a deep water table.

The rocks with large openings are (1) soluble rocks, such as limestone, gypsum, and rock salt, in which caverns form; (2) extrusive basalt with many open cracks, partings between flows, flow breccias, and vesicular and scoriaceous portions; (3) faulted and shattered rocks, usually in small areas; and (4) coarse boulder beds laid down by rivers, by glacial ice, or more rarely by landslide slumping.

In Figure 1 the reservoir $A^{\prime}$ is constructed in an area with a deep water table draining on a flat gradient to valley $C^{\prime}$. The losses from the reservoir are proportionate to the hydraulic head and the capacity of the rock to transmit water. In the absence of data by which they can be estimated, judgment must be used as to whether the losses will be excessive or not. In one locality part of the bed of a proposed reservoir in extrusive basalt was annually flooded by farmers with water from the spring freshets of near-by creeks. Water 15 feet deep disappeared in six weeks, and as the proposed dam contemplated a depth of 60 feet of water, it seemed likely that the whole content of the reservoir might be lost in say three months. Part of the floor was covered with fine-grained soil which retarded leakage, but with the high velocities engendered by a 60 -foot head much of this material would undoubtedly be carried down into the basalt and the rate of leakage would increase. Consequently the project was abandoned.

The Jerome Reservoir, in Idaho, is situated in a depression underlain by several hundred feet of basalt flows. The water table is far below the surface, and leakage through the basalt, though the rock was protected by a cover of soil 10 feet thick in places, was so great as to cause the abandonment of the reservoir. The Hondo Reservoir, in southeastern New Mexico, is situated in a natural depression surrounded by fairly substantial limestone. Below a surface soil the floor is underlain by shale and gypsum, as shown by drill holes, and according to the best information the water table lies about 200 feet below it. After the reservoir was constructed leakage through the cavernous rock beneath it was so rapid as to cause the formation of sinkholes in the soil, and the loss of water was so great that the reservoir was abandoned.

The Deer Flat Reservoir, also known as Lake Lowell, a part of the Boise irrigation project, in Idaho, is situated on an undulating plain between Boise and Snake Rivers. The reservoir is formed by two 
embankments that close gaps in encircling hills. These embankments are not absolutely tight and allow some seepage at the base. When first filled this reservoir had a relatively large loss of water from the floor and sides, but the loss has gradually diminished, as shown in the following table, the data for which have been supplied by the Bureau of Reclamation:

Losses of water from Deer Flat Reservoir, Idaho, 1909-1921

\begin{tabular}{|c|c|c|c|c|c|c|}
\hline Year & $\begin{array}{c}\text { Maxi- } \\
\text { mum } \\
\text { area sub- } \\
\text { merged } \\
\text { (acres) }\end{array}$ & $\begin{array}{c}\text { Mean } \\
\text { area sub- } \\
\text { merged } \\
\text { (acres) }\end{array}$ & $\begin{array}{c}\text { Evapora- } \\
\text { tion } \\
\text { (acre-feet) }\end{array}$ & $\begin{array}{l}\text { Total loss } \\
\text { (acre-feet) }\end{array}$ & $\begin{array}{c}\text { Seepage } \\
\text { loss } \\
\text { (acre-feet) }\end{array}$ & $\begin{array}{l}\text { Average } \\
\text { seepage } \\
\text { loss per } \\
\text { acre sub- } \\
\text { merged } \\
\text { (acre-feet) }\end{array}$ \\
\hline $\begin{array}{l}1909 \\
1910 \\
1912 \\
1913 \\
1915 \\
1916 \\
1918 \\
1919 \\
1920 \\
1921\end{array}$ & $\begin{array}{l}2,500 \\
3,900 \\
6,300 \\
7,000 \\
8,200 \\
8,400 \\
8,100 \\
6,900 \\
7,550 \\
9,311 \\
9,535 \\
9,768 \\
9,835\end{array}$ & $\begin{array}{l}1,355 \\
3,002 \\
4,459 \\
4,625 \\
5,250 \\
5,337 \\
5,123 \\
4,820 \\
4,500 \\
6,171 \\
6,019 \\
6,388 \\
7,279\end{array}$ & $\begin{array}{r}4,750 \\
10,500 \\
15,600 \\
16,200 \\
18,200 \\
18,700 \\
17,900 \\
16,900 \\
11,000 \\
13,398 \\
13,565 \\
14,968 \\
25,035\end{array}$ & $\begin{array}{r}57,500 \\
93,483 \\
150,838 \\
85,089 \\
89,489 \\
82,084 \\
67,400 \\
43,970 \\
32,400 \\
54,816 \\
44,974 \\
62,954 \\
66,668\end{array}$ & $\begin{array}{r}52,850 \\
84,983 \\
135,238 \\
68,889 \\
71,089 \\
63,384 \\
49,500 \\
26,141 \\
22,138 \\
41,418 \\
31,409 \\
47,986 \\
41,633\end{array}$ & $\begin{array}{r}39.0 \\
28.3 \\
30.3 \\
14.9 \\
13.5 \\
12.0 \\
9.7 \\
5.4 \\
4.9 \\
6.7 \\
5.2 \\
7.5 \\
5.7\end{array}$ \\
\hline $\begin{array}{l}\text { Mean } \\
\text { Total }\end{array}$ & 7,485 & 4,948 & $\begin{array}{r}15,132 \\
196,716\end{array}$ & $\begin{array}{r}71,666 \\
931,665\end{array}$ & $\begin{array}{r}56,666 \\
736,658\end{array}$ & 11.4 \\
\hline
\end{tabular}

a The mean of the last colımn is the result of dividing the mean of the seepage loss by the mean acreage submerged.

The underlying materials consist of horizontal soft sedimentary beds, mostly clay, tuff, and sand of the Payette and possibly the Idaho formation. I few basalt flows are interbedded with the other materials, and on the surface of the plain are discontinuous deposits of gravel. Before the reservoir was built the water table rose under this plain above the level of the adjacent rivers but did not closely approach the surfaie. The losses of the early years of the reservoir went largely into saturating the underlying beds and raising the water table. The irrigation of surrounding land was begun at the same time and assisted in this process, so that at present the reservoir rests on saturated ground to which it loses only enough water to replace that drawn off by lateral movement to swampy places on the hillsides or to the rivers. Doubtless silting of the bottom of the reservoir has also helped to prevent losses. It is evident that if the underlying materials were more permeable it would require more water to replace that lost by lateral flow. If, for example, the material were a coarse gravel the losses of water might have been so great as to destroy the value of the reservoir.

On South Platte River, in Colorado, several storage reservoirs ${ }^{16}$ have been built in natural depressions among sand dunes adjacent

10 Parshall, R. L., Return of seepage water to the lower South Platte River in Colorado: Colorado Agr. Coll. Exper. Sta. Bull. 279, pp. 58-64, 1922. 
to the river. Seepage losses from these reservoirs have been large, but as shown in the table below the loss decreases with age of the reservoir. This fact indicates that the seepage has built up the zone of saturation in the ground to a higher level and thus decreased the gradient of the new water table and consequently the rate of movement of water through the ground. It is also probable that the deposition of silt in the reservoirs has tended to seal the bottoms and thus has cooperated in preventing seepage.

Seepage from reservoirs of the South Platte Valley, Colo., in 1920

\begin{tabular}{|c|c|c|c|c|c|c|c|}
\hline Name & $\left|\begin{array}{c}\text { Date of } \\
\text { construc- } \\
\text { tion }\end{array}\right|$ & $\begin{array}{c}\text { Age at } \\
\text { time of } \\
\text { measure- } \\
\text { ment } \\
\text { (years) }\end{array}$ & $\begin{array}{c}\text { Capacity } \\
\text { (acre- } \\
\text { (eet) }\end{array}$ & $\begin{array}{c}\text { Maxi- } \\
\text { mum } \\
\text { height } \\
\text { of dam } \\
\text { (feet) }\end{array}$ & $\begin{array}{c}\text { Area at } \\
\text { high } \\
\text { water } \\
\text { (acres) }\end{array}$ & $\begin{array}{c}\text { Loss of } \\
\text { water by } \\
\text { seepage } \\
\text { and evap- } \\
\text { oration } \\
\text { for 12 } \\
\text { months } \\
\text { (acre- } \\
\text { feet)a }\end{array}$ & $\begin{array}{c}\text { Percent- } \\
\text { age of } \\
\text { water } \\
\text { dehivered } \\
\text { to } \\
\text { reservoir }\end{array}$ \\
\hline $\begin{array}{l}\text { Jackson Lake } \\
\text { Riverside Reservoir- } \\
\text { Prewitt Reservoir }-. . \\
\end{array}$ & $\begin{array}{l}1903 \\
1909 \\
1912\end{array}$ & $\begin{array}{l}17 \\
11 \\
8\end{array}$ & $\begin{array}{l}35,400 \\
57,500 \\
32,800\end{array}$ & $\begin{array}{l}20 \\
25 \\
37\end{array}$ & $\begin{array}{l}2,546 \\
3,595 \\
2,431\end{array}$ & $\begin{array}{l}10,610 \\
60,850 \\
34,990\end{array}$ & $\begin{array}{l}24 \\
46 \\
58\end{array}$ \\
\hline
\end{tabular}

a Data sufficient to separate evaporation losses from seepage are not available.

In the investigation of reservoir sites the geologist must guard himself against accepting evidence without analysis. One of the most deceptive conditions is the presence of a perennial stream in the valley that is proposed for use as a reservoir. Is this stream fed by ground water, and does it represent the lowest zone of the local water table? In general, areas of high water table are characterized by many perennial streams, and areas of low water table have feeble surface drainage. As brought out in the investigation of the No. 3 Reservoir' of the Carlsbad irrigation project, ${ }^{17}$ in New Mexico, Pecos River at the dam site is perched above a low-lying water table. The test well at this point encountered water. between 24 and 42 feet, which stood at 24 feet below the surface and 12 feet below the level of the river. Below this wet zone the cavernous rocks were dry to a depth of 72 feet. From this depth to 152 feet water was found, which stood at 72 feet and is probably the main zone of saturation of the region. Pecos River runs above dry rock in a kind of natural flume, which was doubtless formed by the deposition of calcium carbonate from the water of the river in the gravel and cave breccia beneath its bed. Obviously, such a "flume" is limited in capacity, as indicated diagrammatically in Figure $1, B^{\prime}$, and if the water level is raised above its sides, any water that spills over may percolate to the deep water table.

${ }^{17}$ Meinzer, O. E., and others, Geology of No. 3 reservoir site of the Carlsbad irrigation project, New Mexico, with respect to water-tightness: U. S. Geol. Survey Water-Supply Paper 580, pp. 1-39, 1926. 
If most of the leakage is confined to small areas, building dikes to isolate these areas is a logical step. Such a dike at the McMillan Reservoir, in New Mexico, failed to stop leakage because openings in the gypsum, previously inconspicuous, enlarged and carried off about the same quantity of water as was lost before the dike was built, and because water moved under the dike, which lacked an impervious cutoff. At other reservoirs such attempts have been of doubtful utility. Where, however, leakage takes place through a single definite underground channel, such as the series of caves in limestone that lead from the upstream to the downstream side of an intrenched meander on Black River, N. Y. ${ }^{18}$ the channel can be found and plugged, but such remedies are suitable only where the water pressure is low. The Malad Reservoir, ${ }^{19}$ in Idaho, as shown by a contour map of the water table in the alluvium of its floor, leaks in a small area, and excavations in this area show many small cavities along the bedding planes of a limestone. Grouting of this area is advocated, and, if there are not other similar areas, this remedy should convert a now useless dam into a useful property.

Occasionally, also, other factors enter into the problems, as at the Cataract Reservoir and dam for the water supply of Sydney, Australia. ${ }^{20}$ Here the reservoir and dam site are underlain at a depth of about 800 feet by valuable coal beds. The prohibition of coal mining under the whole drainage basin or at least under the reservoir site was advocated, but the geologists held that the value of the coal, even at a moderate estimate of the quantity, exceeded the value of the reservoir. They believed, too, that the cover above the coal, consisting largely of sandstone, was sufficiently strong to permit mining not only in the drainage basin but under the reservoir. Under the dam a barrier pillar 1,800 feet wide was specified. However, the wisdom of mining under the reservoir will await its test in the future, when the relative value of the stored water and of the coal may have changed. It may then be feasible as the coal is mined to insert masonry supports for the roof and thus insure that no subsidence and consequent leakage shall take place.

The study of a reservoir site involves large responsibilities for the geologist, because remedial measures against leakage are seldom possible. His conclusions can not be tested save by the expensive method of constructing and filling the reservoir. If he approves

\footnotetext{
${ }^{18}$ Stopping underground leakage from power dam: Eng. News-Record, vol. 76, pp. 459$460,1916$.

19 Stearns, H. T., Porosity of reservoir prevents water storage, Malad Reservoir, Idaho : Eng. News-Record, vol. 96, p. 561, Apr. 8, 1926.

${ }^{20}$ Wade, L. A. B., The construction of the Cataract Dam, Sydney, N. S. W. (abstract) : Fng. News, vol. 63, pp. 713-716, 1910. Quotes geologic report by E. J. Pittman and A. A. Atkinson.
} 
the site and after construction the reservoir fails to hold water, the investment is lost; if he condemns the site and no substitute can be found, the project is abortive. In examinations of other types of sites the difficulties that he may point out can by ingenuity and sufficient expenditure be overcome, but as to reservoirs he must bear the responsibility alone. It therefore behooves the geologist charged with such duty to determine the ground-water conditions with exactness, to require the drilling of test wells at critical points, and then to analyze his data with care and in humbleness of spirit.

\section{DAM SITES}

\section{GENERAL CONDITIONS}

The study of dam sites excites the interest of geologists because of the necessity for precise and detailed work and because funds are usually available for test pits and borings to gain information not obtainable by surface examination. The many devices available to the engineer to overcome difficulties at the site are each limited by various related conditions. Consequently the geologist must be scrupulous to set forth all the facts at his disposal. He should also realize that if adequate funds are available every difficulty can be overcome and that dam sites are abandoned only because the cost of the proposed dam exceeds its probable value. The economic changes of the future may change the ratio of value, and structures now unfeasible may some day be built. The feasibility of a dam is thus an economic problem, and statements as to feasibility are outside the province of a geologist's report, which should be confined to the physical conditions.

A dam consists of an impervious or nearly impervious membrane, supported against the thrust of impounded water. ${ }^{21}$ In the ordinary masonry or concrete dam the impervious membrane is a layer of the first few inches or feet of the upstream side of the wall, but in other types of dams the membrane may be a separate structure, and in earth dams no part of the structure may be wholly impervious, but the flow of water is prevented by frictional resistance to movement offered by successive portions of the embankment. The geologist is not concerned with the methods by which the membrane and its supporting structure shall be built except in relation to the geologic diffculties, and he should avoid expressions that give him the appearance of dictating engineering details to the designer. Thus, in a recent geologic report the author, because of unequal bearing power of the north and south halves of the site, strongly recommended an earth

${ }^{21}$ Dillman, G. L., Am. Soc. Civil Eng. Trans., vol. 75, p. 52, 1912. For types of dams see the numerous textbooks. 
dam, which could yield unequally without rupture, and condemned a concrete dam. As there was no earth available the designers adopted a flat-decked cellular structure of reinforced concrete, for this type of dam is also flexible. The geologist was therefore left in the embarrassing position of having condemned the type of dam selected, although his warning as to geologic conditions was accepted and met by the design.

The geologist is interested primarily in the load that the dam will form and in the location of the impervious membrane and the depth to which it is to be carried in order to shut off leakage. Masonry and concrete dams, which resist the thrust of the impounded water by their weight or by the strength of a single arch, have narrow bases and impose a large load on each unit area of their foundations. If the rocks seem unsuitable for such a load, the geologist may recommend a wide-base dam instead of a narrow-base dam, but he should avoid expressing an opinion as to whether a dam of rock fill, earth, cellular concrete, or any of the numerous alternatives will best meet the need. The generic terms "wide base" and "narrow base" are the best to use, as they give the designer of the structure no superfluous instructions. Similarly the geologist may specify that the impervious membrane shall be carried through a certain pervious rock into an impervious one, or he may state that a mechanical connection between the impervious or nearly impervious portion of the dam and a certain formation below should be made. The choice of methods whereby the object can be accomplished properly belongs to the engineer, who may use sheet piling, pressure grouting, or a wall of masonry, concrete, or puddled clay.

The geology of dam sites may be considered under the following heads : Foundations; abutments (leakage); spillways; tunnels (bypass, discharge, etc.); materials for construction. This division is quite arbitrary, however, because the factors are so related that in the examination of any one site all must be considered. The cost of construction is also a part of the problem, and intelligent geologic work can be done only in conjunction with the engineer, in whose study of the problem this consideration is prominent. For instance, at a site where large quantities of earth are available and rock suitable for masonry or concrete is absent, relative costs usually indicate that the dam should be an earth structure. As in this type of dam the load per square foot on the foundation is moderate, because of the broad base, the examination of the foundation in this respect may consequently be perfunctory. Yet there are foundations so soft that the weight per unit area even of ordinary earth dams exceeds the bearing power. 


\section{FOUNDATIONS OF DAMS}

The most common type of dam site lies in a narrow part of a valley where the rock of the abutments of the dam is more or less visible but the bottom of the cross section is covered with the alluvium of the stream. The first question to be answered is the depth of this alluvium. If there are many bedrock outcrops projecting through the alluvium the geologist may hazard an estimate of its average thickness. In general, however, the depth to bedrock can not be predicted with any certainty. The writer has vividly in mind a rocky gorge about 250 feet wide with nearly vertical sides that extend for about half a mile along a small river in the southwestern United States, in which it was proposed to place a low diversion dam. At the head of the gorge bedrock projected from the gravel of the stream channel, and several similar outcrops lay at the lower end of the gorge. It seemed that the stream must be eroding the rock floor, and that the gravel of the channel down to bedrock was removed by each great flood. Considering the size of the stream, 30 feet of gravel appeared to be a liberal estimate, and such a depth would make possible a concrete or masonry dam founded on bedrock. A test drill hole, however, penetrated 81 feet of sand and gravel without reaching rock. Under the prevailing economic conditions this was a prohibitive depth, and consequently a floating or Indian type weir was designed for the site.

Before estimates of cost are made test drill holes are put down at most sites to determine the depth to bedrock, but in reconnaissance surveys a geologist is often called upon to express an opinion, and he must, bearing in mind the hazards of mistakes, weigh carefully the somewhat inadequate data that he may obtain. First, is the stream degrading or aggrading its bed? If it is aggrading the depth of the alluvial fill may be very great, whereas if the stream is still degrading its bed the alluvium over which it runs at ordinary stages is removed in floods, and the stream is said to scour and fill. The depth to which scour and fill can be carried on is a function of the size and velocity of floods and of the quantity of material to be carried through the bedrock channel. It is seldom possible to obtain adequate data to solve the equation indicated above, but by bringing together the results of other lines of reasoning a result of some value can be obtained, as ably demonstrated by Miser ${ }^{22}$ in his study of the fill in San Juan Canyon.

In a narrow gorge of a northwestern river it was proposed to set two bridge piers in the channel at the site of a sand bar. The

${ }^{22}$ Miser, H. D., The San Juan Canyon, southeastern Utah, a geographic and hydrographic reconnaissance: U. S. Geol. Survey Water-Supply Paper 538, pp. 58-71, pl. 22, 1924. 
geologist was required to predict at what depth rock would be encountered beneath this bar in order that preliminary estimates of cost could be made. The valleys upstream and downstream from this canyon are underlain by 300 feet or more of alluvium, and deep gravel-filled channels are characteristic of rivers in this general region. Investigation showed that the present course of the river in the canyon does not correspond to its ancient course. The shift in position took place by lateral meandering at the level of a terrace 160 to 180 feet above the river. The ancient course is filled with gravel to and perhaps below river level. The newer course is doubtless postglacial. As the site of the bridge piers is in the new course of the river it seemed unlikely that the river had formed a deep channel in so short a time, and the depth to bedrock should, therefore, not exceed the depth of scour and fill. The prediction was made that the depth would not exceed 30 feet, and later test drill holes showed a depth of 29 feet.

Preliminary test drilling for a recently constructed dam indicated a moderate depth to bedrock. However, as the river bed was bared to lay the foundations a narrow cleft or rock channel 70 feet deep was discovered which lay between drill holes only 50 feet apart. This irregularity in the stream bottom was more costly because unexpected. Caution in interpreting the results of drill holes and the use of a greater number to define the bedrock channel are obviously indicated by the experience gained at this dam site.

If the alluvial fill is moderate and the gorge narrow, a masonry dam of gravity or arch section may be considered. Such a dam has a narrow base and places a concentrated load on the foundations. The rock must be able to resist this load. Rocks such as would be considered good building stone ordinarily are entirely strong enough, as their compressive strength exceeds that of the masonry or concrete. However, the joints, bedding planes, and other natural fractures of rocks reduce their strength below that shown in test specimens, and because the effect of these natural weaknesses can not be closely estimated, it is customary to use a large margin of safety.

The presence of clay in the joints or as thin seams along the bedding planes of otherwise sound and strong rocks is a source of danger. Under the increased pressure due to impounding of water in the reservoir, water may be forced into these clay seams and convert them into gliding planes on which movement can take place with little friction. This Iubrication of the bedding planes of thin-bedded rocks, such as some sandstones and limestones, will permit the dam to slide forward and rupture. At such sites the rock with clay seams may be removed or percolation through the foundations may be prevented by pressure grouting, or some form of wide-base dam may be used. 
Poorly cemented sandstone, porous limestone, tuff, certain breccias, and agglomerate and similar rocks may be massive but áre deficient in strength. A single field-loading test of an agglomerate at the site of the proposed Iron Canyon Dam ${ }^{23}$ in California indicated that the rock would stand a load of 40 tons to the square foot without signs of failure, but a board of engineers decided that the dam should impose only half as great a load on the rock. Thus they introduced an apparently large factor of safety to provide for the uncertainties arising from a single test on only a portion of the rock and for two other uncertainties due to the fact that the test was made on dry rock, whereas the foundation of the dam would be wet, and that the test occupied only a short time, whereas the dam was expected to stand for many years, during which slow yielding might take place. Following similar reasoning, the engineers who conducted the remarkable field tests of the loosely cemented Dakota sandstone on the site chosen for the new State capitol at Lincoln, Nebr., ${ }^{24}$ showed that the rock would stand more than 60 tons to the square foot, but they decided that 15 tons was a maximum safe load. The architect who designed the footings of the great tower of this building reduced this loading to 12 tons to the square foot.

Field tests are compared to laboratory tests on clay in the account of the investigations of the foundation conditions of a high building at Columbus, Ohio. ${ }^{25}$ Tests on cubes showed a compressive strength on the average only 31 per cent as great as that of the material in place. The bearing power of soft clay is much increased when it is kept dry, as indicated by the successful drainage of foundations at. Cleveland. ${ }^{26}$

Qualitative data for determining the ability of the natural foundations to stand the load of a high masonry dam at a site where quantitative data are needed are given by La Rue ${ }^{27}$ and by Bryan. ${ }^{28}$ An examination of the reports mentioned above and a consideration of the following standard table will give a geologist a fair idea of the bearing capacity of the softer rocks and of unconsolidated materials.

${ }^{23}$ Gault, H. J., and McClure, W. F., Report on Iron Canyon project, California, p. 66, U. S. Recl. Service, 1921. Gault, H. J., Test of bearing capacity of rock at Iron Canyon dam site, California: Reclamation Record, vol. 11, pp. 378-379, 1920; abstract, Eng. News-Record, vol. 85 , p. $417,1920$.

${ }^{24}$ Foundation tests for Nebraska State Capitol : Eng. News-Record, vol. 89, pp. 606-609, Oct. 12, 1922. Chambers, R. H., Heavy foundations on sandrock, Nebraska Capitol : Idem, vol. 94 , pp. 107-108, 1925 .

${ }^{25}$ Waring, R. L., and Morris, C. T., Bearing-power tests on deep caisson foundations : Eng. News-Record, vol. 96, pp. 109-112, 1926.

${ }^{26}$ Betz, F. H., Deep drainage of foundation soll for heavy building : Eng. News-Record, vol. 80 , p. $363,1918$.

${ }^{27}$ La Rue, E. C., Water power and flood control of Colorado River below Green River, Utah: U. S. Geol. Survey Water-Supply Paper 556, pp. 20-24, 1925.

${ }^{28}$ Bryan, Kirk, Discussion on geologic setting of rock-fll dam at Lees Ferry, Ariz.: Am. Soc. Civil Eng. Trans., vol. 86, pp. 228-240, 1923. 


\begin{tabular}{|c|c|c|}
\hline \multirow{2}{*}{ Kind of material } & \multicolumn{2}{|c|}{$\begin{array}{l}\text { Tons }(2,000 \text { pounds } \\
\text { to the square foot } a)\end{array}$} \\
\hline & $\underset{\text { load }}{\text { Minimum }}$ & $\underset{\text { load }}{\text { Maximum }}$ \\
\hline $\begin{array}{l}\text { Rock, the hardest, in thick layers in native bed } \\
\text { Rock equal to best as hlar masonry } \\
\text { Rock equal to best brick masonry } \\
\text { Rock equal to poor brick masonry } \\
\text { Clay in thick beds, always dry } \\
\text { Clay in thick beds, moderately dry } \\
\text { Clay, soft } \\
\text { Gravel and coarse sand, well cemented, } \\
\text { Sand, dry, compact, and well cemented } \\
\text { Sand, clean, dry } \\
\text { Quicksand, alluvial soil, etce }\end{array}$ & $\begin{array}{r}200 \\
25 \\
15 \\
5 \\
6 \\
4 \\
1 \\
8 \\
4 \\
2 \\
\\
.5\end{array}$ & $\begin{array}{r}30 \\
20 \\
10 \\
8 \\
6 \\
2 \\
10 \\
6 \\
4 \\
1\end{array}$ \\
\hline
\end{tabular}

a 1 ton to the square foot $=138.8$ pounds to the square inch, and 1 pound to the square inch $=0.072$ ton to the square foot. Merriam, Mansfield, American Civil Engineer's Pocket Book, 3d ed., p. 528, 1916.

These data lead, however, only to empiric results. The principles of the yield of sand and clay to load have been ably discussed by Terzaghi, ${ }^{29}$ whose work should be studied by all geologists concerned with such problems.

At sites where rocks of unequal bearing capacity cccur differential settlement of the dam may result. If, for example, the abutments are of hard rock, and the dam is to rest mainly on the alluvium of the valley, which is not to be excavated, provision must be made for greater settlement of the center of the dam than of the ends. Similarly a valley in horizontal bedded rocks may have walls of hard rock, such as sandstone or limestone, and a floor of shale. The geologic conditions that present such inequalities are numerous, but the devices for providing flexibility in the impervious membrane and in the supporting structure are almost equally numerous and can be most economically planned when the geologic conditions have been closely and accurately defined.

A misinterpretation of geologic conditions during preliminary examination involved additional trouble and expense in building a dam recently completed. ${ }^{30}$ What appeared to be a coarse, almost conglomeratic sandstone proved to be a soft sandstone with soft shale layers. The loading was reduced from 15 to 6 tons to the square foot. A cut-off wall 10 feet deep was built, and much grouting was done to prevent percolation through the rock under the dam.

In addition to the bearing capacity of the rock of the foundations, the number and kind of openings in the rock must be considered. If

Terzaghi, Charles, Principles of soil mechanics: Eng. News-Record, Fol. 95, seven articles, November and December, 1925.

- so McEwen, A. B., Combined railway, bridge, and dam built at outlet of Grand Lake, Newfoundland: Eng. News-Record, vol. 99, pp. 128-132, 1927. 
there is free communication from the reservoir through these openings uplift pressure ${ }^{31}$ on the base of the dam proportional to the depth of water in the reservoir will result. This pressure must be allowed for in the design of the dam. Leakage must also be expected, although the quantity of water lost may be so small as to be negligible. However, if the rock is soluble or contains soluble parts, or if fine material such as sand is eroded from the rock by the flowing water, the leaks may increase, with a resulting loss in water and weakening of the foundation.

For these reasons the impervious portion of a dam is carried to "sound rock," and pressure grouting is employed to cut off leakage. The questions involved in determining what is "sound rock" are discussed on page 22. Pressure grouting is a process by which a material, such as Portland cement mixed thin, is forced into drill holes in a rock to fill cavities and prevent the passage of water. This process is relatively cheap and is remarkably effective under suitable conditions. As ordinarily applied, the grout penetrates and fills all cracks and joint fissures between the drill holes, but does not penetrate the pores of the rock. However, the François system of grouting, recently invented by a Belgian, makes use of a preliminary treatment with chemicals, usually silicate of soda and sulphate of alumina, which facilitate the movement of the grout injected later. By the use of this process ${ }^{32}$ cracks and joints in sandstone that were filled with loose sand have been successfully grouted, and gravel beds have been so thoroughly cemented as to cut off the flow of water and make possible excavation by pick and shovel. A shaft ${ }^{33}$ was sunk through loose, water-bearing material with ease, and about 80 per cent of the water that would otherwise have entered was excluded from the excavation..$^{3}$

As yet this variation of the process of cement grouting has not become current in the United States, although experiments ${ }^{34}$ on cementing gravel have been made with some success. The difficulty of proving that grouting has been successful and the possibility that ungrouted areas may remain have so far weighed heavily against too much dependence on grouting either for reinforcing foundations or for providing adequate cut-off curtains. As usually applied, grouting

a Consult textbooks on dams, also Tests of water pressures under Brule River Dam [Wis.] : Eng. News-Record, vol. 96, p. 275, 1926.

${ }^{2}$ Ball, H. S., The application of cementation to mining: South Wales Inst. Eng. Proc., vol. 36, pp. $517-565,1921$.

${ }^{33}$ Mitton, H. E., The sinking of a colliery in the East Nottinghamshire coal field: Inst. Min. Eng. [England] Trans., vol. 70, pp. 345-367, 1926. See also Blanford, T., The cementation process as applied to mining: Idem, vol. 53, pp. 22-29, 1917, and Horsam, A., and Mawson, T. T., Sinking a shaft by the François cementation process: Idem, vol. 58, pp. 16-28, 1920.

34 Cartwright, H. H., Tests of grouting gravel in river beds: Eng. News, vol. 69, pp. 979-984, 1913. See also idem, pp. 969-970, and discussion of Estacada Dam cited on p. 19. 
is most successful in clean fissures. Thus at the Hales Bar Dam, ${ }^{35}$ in Tennessee, where the foundation consists of limestone in which are many caverns, most of them filled with clay, those caverns that were free of clay were successfully grouted by the use of $10,000,000$ pounds of Portland cement. The clay in other cavities and caverns, which the grout could not enter, was gradually washed out. Serious leakage through the foundation below this dam then ensued, but recent grouting with hot asphalt appears to have reduced the leakage effectively. ${ }^{36}$

The difficulties of grouting in volcanic breccia and the advisability of using a grouted curtain as a cut-off wall have been discussed in regard to the Estacada Dam, in Oregon. ${ }^{37}$ Much more successful grouting was accomplished in the metamorphic rock with clean fractures underlying the Lahontan Dam, in Nevada, ${ }^{38}$ and in the sandstone and shale underlying the Olive Bridge Dam, in New York. ${ }^{39}$ In these two dams grouting was merely supplemental to cut-off walls that might have prevented dangerous percolation beneath the dam without the additional precaution of grouting.

The geologist should therefore make such observations as will enable him to state the number and spacing of joints and bedding planes and the probability of the existence of cavities and caverns. He should also be able to state whether these openings have been sealed with mineral matter deposited by natural processes, or have been filled with sand or clay, or are so clean and open as to be readily grouted. The likelihood that limestone may be cavernous should be borne in mind, but on the other hand it should be remembered that very large dams ${ }^{40}$ of unquestioned stability and water-tightness have been built in this rock with little difficulty. One in southern Spain on Jurassic limestone is 273 feet high and 200 feet long, and another, built for the Baker power plant, in Washington, is 263 feet

\footnotetext{
${ }^{35}$ Switzer, J. A., The power development of Hales Bar : Resources of Tennessee, vol. 2 , pp. 86-99, 1912. Rock grouting and caisson sinking for the Hales Bar Dam: Eng. News, vol. 70, pp. 949-956, 1913.

${ }^{36}$ Christians, G. W., Asphalt grouting under Hales Bar Dam : Eng. News-Record, vol. 96, pp. 798-802, 1926.

${ }^{37}$ Rands, H. A., Grouted cut-off for the Estacada Dam : Am. Soc. Civil Eng. Trans., vol. 78, pp. 447-482; discussion, pp. 483-546, 1915. See also, on grouting, Wait, B. H., Driving a wet aqueduct tunnel in hard rocks : Eng. News, vol. 63, pp. 660-662, 1911; Angas, W. M., Repairing leaks in a dry dock by grouting: Am. Soc. Civil Eng. Trans., pp. 579-596; discussion, pp. 597-598, 1925 ; and Dreyer, W., Volcanic formations govern design in Pit River No. 3 hydroelectric development [Calif.] : Eng. News-Record, vol. 96, pp. 144-149, 1926.

${ }^{38}$ Cole, D. W., Making a cut-off wall by grouting fissured rock, Lahontan Dam: Eng. News, vol. 69, pp. 647-651, 1913. See also editorial article, idem, pp. 969-970, and letter of H. A. Rands, idem, p. 1190.

$\approx$ Grouting the Olive Bridge Dam : Eng. Record, vol. 63, pp. 385-386, 1911.

${ }^{10}$ Wegenstein, M. E., High arch type dam buili in south Spain : Eng. News-Record, vol. 93, pp. 128-130, 1924. High overfiow dam, main unit of Bakex power plant [Wash.] : Eng. News-Record, vol. 96, pp. 360-362, 1926. Gowen, C. S., The foundations of the new Croton Dam : Am. Soc. Civil Eng. Trans., vol. 43, pp. 468-542, 1900.
} 
high and 493 feet long and rests on limestone that below river level was pitted with potholes and roughened with ridges. The foundation of the Keokuk Dam across the Mississippi is limestone which was so hard and sound that except for a small cut-off trench it was merely scrubbed to clean it for the reception of the concrete, and pressure grouting was not used. However, many engineers hold that pressure grouting is so cheap that it should always be used at the heel of a dam as an additional factor of safety.

The history of the old Austin Dam, on Colorado River, in Texas, as recounted by Taylor, ${ }^{41}$ and the reinvestigation of the old dam and the difficulties in construction of the new dam, as recounted by Mead, ${ }^{42}$ should cause hesitation in attempting a large dam in horizontal limestone, especially if the rock is fractured and weathered, unless complete investigation has been made and every precaution taken. Here after the completion of the new dam at least 86 cubic feet of water a second leaked through the zone immediately around the dam and through pervious strata and fissures in the canyon walls at some distance from the dam. Part of this seepage was taking place through clay-filled fissures below the foundations and with undermining of the toe by the overfall of flood waters produced imminent danger of the forward sliding of the dam. A thorough study of the difficulties encountered at this site and the failures induced by measures inadequate to meet these difficulties will enable a competent judgment to be made of the dangers of similar sites in flat-lying, more or less fractured and weathered limestone.

At many dam sites the depth to bedrock in the stream channel is so great that it is impracticable or too expensive to build a masonry dam founded on rock. At such places earth or rock-fill dams are ordinarily used, but multiple-arch dams, ${ }^{43}$ flat-decked cellular dams, or sluice-gate sections of masonry have also been built.

The requirement concerning leakage for dams constructed on soft and porous foundations is that percolation of water under the dam shall be so restricted that the velocity of flow will be inadequate to entrain sand or clay and to carry this fine material out from under the dam. Obviously if fine material is carried away from the foundations the leakage will increase, the holes will enlarge, and finally settlement will take place. As a consequence of settlement cracks will open in the dam, and, with the pressure of the water in the reservoir to assist, the structure may collapse.

\footnotetext{
41 Taylor, T. U., The Austin Dam: U. S. Geol. Survey Water-Supply Paper 40, 52 pp., 16 pls., 12 figs., 1900.

${ }^{42}$ Mead, D. W., Report on the dam and water-power development at Austin, Tex., 205 pp., privately printed, November, 1917.

${ }^{43}$ Parsons, H. de B., Sherman Island dam and power house : Am. Soc. Civil Eng. Trans. vol. 88, pp. 1257-1292; discussion, pp. 1293-1328, 1925 .
} 
The flow under such dams is a function of the height of the dam and the permeability of the material of the foundation. Theoretically the equations representing this function may be solved by the collection of adequate data, and the reader is referred to the interesting attempt at such a solution by Justin, ${ }^{44}$ whose paper contains a comprehensive list of successful earth dams and of failures and partial failures of such structures.

In general, the materials under a dam are of irregular permeability and may range from gravel to clay. Cut-off walls or lines of sheet piling or both are used where possible to retard flow, but unless these structures reach bedrock they serve merely as baffles to increase the distance of flow. Similarly, a blanket of clay or concrete connecting with the impervious part of the dam may be built on the reservoir floor upstream from the dam to increase the length of travel. The ratio of the distance of flow (including the blanket, the cut-off wall, and the impervious portion of the dam) to the height of water to be resisted is called the percolation factor. ${ }^{45}$ This factor ranges from 5 to 20 in successful dams. The smaller factor is used for gravel, in which there is less danger of the entrainment of material or "piping" under the dam, and the factor of 20 is used for fine material described as "quicksand."

Usually the nature of materials under a river valley is not clear unless test borings can be made. With access to the samples and drill logs thus obtained the geologist can often interpret the data so as to solve some of the problems of earth and rock-fill dams.

At a certain dam site a narrow gorge in granite gneiss, otherwise suitable for dams, was filled to a depth of 83 feet with a swamp deposit which at the surface, in a narrow strip on each side of the stream, formed a quaking bog. The first set of drill holes was interpreted as indicating clay beds at the bottom, resting on the bedrock. Such clay beds would have offered a tight seal for sheet piling either for a cut-off wall or for a cofferdam. The samples from a second set of drill holes were examined by a geologist, who showed that the supposed clay was an impure diatomaceous earth without stability. This material and the overlying muck were so fine grained and unconsolidated and had so high a content of water that excavation of the dam site to bedrock for any type of dam involved the use of slopes of 4 on 1 or flatter. The enormous exca-

\footnotetext{
14 Justin, J. D., The design of earth dams: Am. Soc. Civil Eng., vol. 87, pp. 1-61; discussion, pp. 62-141, 1924.

45 Bligh, W. G., Dams, barrages, and weirs on porous foundations : Eng. News, vol. 64, pp. 708-710, 1910. Lessons from the failure of a weir and sluices on porous foundations : Idem, vol. 69, pp. 266-270, 1913. See, as examples of high dams built on these principles, Henny, D. C., Two earth dams of the United States Reclamation Service: Am. Soc. Civil Eng. Trans., vol. 74, pp. 38-86 ; discussion, pp. 87-93, 1911.
} 
vation required by the use of these slopes appeared to be too expensive for consideration. The site was abandoned, and a near-by site less favorable topographically was selected.

If it can be shown that an impervious clay bed extends up and down stream for some distance, the impervious part of the dam can be extended to this bed, and the percolation. factor may then be considered to be the ratio of the length of this bed to the height of the impounded water. If the alluvial materials are sufficiently well known from test borings, various devices of this type may be used to attain the desired percolation factor with minimum cost. Obviously very close association between geologist and designer is necessary to take cognizance of all the intricacies of the site.

\section{ABUTMENTS OF DAMS}

The abutments of dams may be hard or soft rock. In the harder rocks joints, cracks, and bedding planes may form passages through which leakage may take place, but if these cracks are clean they may be grouted under pressure and made water-tight. Abutments of basalt must be regarded with suspicion on account of the many openings that may occur in such rock. These openings may permit leakage, but they are not likely to enlarge, and the stability of the abutment is not menaced by them. Limestone, however, and the still more soluble gypsum and rock salt give rise to large cavities that will, as leakage goes on, increase in size. Obviously if the abutments are broad, these defects are relatively unimportant, whereas if the abutments are narrow ridges, not much wider than a dam, joint cracks and other crevices have more weight as unfavorable factors.

The rock of the abutments that has been exposed to the weather is more or less unsound and should be removied to a depth sufficiently great so that the impervious portion of the dam may rest on "sound rock." The cost of this excavation and the cost of the material placed in it must be estimated by the engineer before construction is begun. Similarly, if the base of the dam or the cut-off structures are to be placed in bedrock, the depth to "sound rock" must be estimated. Unfortunately; this estimate is beset with difficulties. Comparative data on this matter have never been compiled. ${ }^{46}$ The geologist is at a disadvantage because of the elasticity of the term "sound rock" and because of the capriciousness of weathering, but he is accustomed to observe the extent and depth of weathering and should be able to assist the engineer in forming a correct judgment as to what depth to "sound rock" to assume. The cut-off wall of one American dam

46 See, however, Lapworth, H., The geology of dam trenches: Inst. Water Eng. Trans., vol. 16, pp. 25-51; discussion, pp. 51-66, London, 1911. 
where it rested on andesite was in places carried 40 feet beyond the "sound rock" line estimated from an examination of drill cores. On the other hand, the recently completed Sennar dam, ${ }^{47}$ in Egypt, rests on gabbro that was found to be less weathered than had been anticipated, and a considerable part of the excavation that had been believed to be necessary was saved.

Abutments in unconsolidated rocks present serious problems, for if leakage takes place the stability of the dam may be menaced. An abutment proposed for a dam may be an interfluve between two adjacent lateral tributaries, and this ridge may be as narrow as the proposed dam. The material of the ridge is unlikely to be as compact or self-draining as a properly made earth dam. If, for instance, it is composed of alternating layers of sand and clay, the sand will admit water which will wet the clay and convert it into slippery mud, so that sloughing and landslides will ensue. In general, therefore, abutments in unconsolidated materials should be wide ridges or interfluves between lateral valleys.

If the material of the abutment is fairly uniform, the normal ground-water gradient in like material in the region may be determined. This gradient projected from the flow line of the reservoir through the abutment should fall within its mass with a good margin of safety. Thus in the study of abutments many of the principles of ground-water hydrology heretofore reviewed with respect to reservoirs come into play. There is, however, this difference-the abutment has a small area, which it may be feasible to blanket with impervious material, or leaky places in it may be cut off from the reservoir by dikes, or part of its material may be used to build the dam and be replaced by an extension of the structure. To supply data for a choice between these alternative devices requires of a geologist detailed and penetrating observations.

The importance of these problems may be appreciated from an examination of the history of a well-known American dam. As first proposed, this dam, an earth structure with concrete core wall, was to close a glacial valley at the place where the glacier had deposited its terminal moraine. On the left abutment the quantity of morainal. material was small, so the outlet tunnel and spillway were located in andesite on this side. On the right the end of the dam was to rest in the terminal moraine. When excavation for the core wall in this abutment was begun, the glacial till of the moraine was found to be wet and clayey. It started to slip into the excavation to such an extent that the site had to be abandoned. The dam was then built 1,000 feet downstream, where both abutments were in andesite. The cost of the abandoned work and the change of plan was very large,

47 Sennar Dam on the Blue Nile in Egypt completed: Eng. News-Record, vol. 96, pp. 316-317, 1926. 
yet evidence that excavation in this abutment was impracticable existed even before the engineers had dug test pits in which unheeded confirmation was obtained. High above the proposed dam the morainal ridge was marked by landslide topography-sure evidence of not very remote slipping. The cause of this slipping was also patent, for the greater number of the boulders in the glacial till are andesite of the easily weathered local type, and each boulder is surrounded with a shell of clay, which when wet forms an ideal lubricant. The fact that the boulders are partly weathered to clay can be seen in natural exposures and was evident in the test pits. The only advantage of the first site over the second was a slightly smaller yardage, which compared to the costs involved in changing from one site to the other could have been only an inconsiderable saving. If in spite of difficulties the dam had been built as started, the effect of the pressure of the reservoir water on the unstable material of the moraine is difficult to predict in detail but could hardly have been anything but disastrous.

Leakage through abutments is described by Henny ${ }^{48}$ in his account of the dams at Cold Springs, Oreg., and Conconully, Wash. The immediate abutments of the Cold Springs Dam consist of basaltic rock of fair quality, but this rock does not extend far into the hills on either side. Seepage through the rock and through the sand and clay beyond the rock is evident but has not been large, as the abutments are wide and the route of travel for the escaping water is very circuitous. Together with seepage through the rock under the dam, which is tied to bedrock by a concrete cut-off wall, the total movement is considerable, though not serious. The visible flow in the creek below the dam ranges from 0.7 to 1.8 cubic feet a second, of which one-fourth may be attributed to losses from the outlet canal. At the Conconully Dam the right or spillway abutment is a narrow ridge of granite and limestone not much wider than the dam and about 600 feet long. A small spring on the downstream side of this ridge had a natural flow of 0.115 cubic foot a second. When the reservoir was filled, the flow from this spring and new springs at 'other places along the ridge increased gradually to a cubic foot a second, and it decreased as the reservoir was emptied. The spring water is clear, showing that no entrainment of material is taking place, and as the leakage can not affect the stability of the abutment it is of little importance. The loss of water is so slight that no remedial measures have been taken, although the area involved is small enough to make either an earth blanket on the reservoir side of the abutment or pressure grouting of the fissured rock entirely practicable.

4s Henny, D. C., Two earth dams of the United States Reclamation Service: Am. Soc. Civil Eng. Trans., vol. 74, pp. 38-86; discussion, pp. 87-93, 1911. 


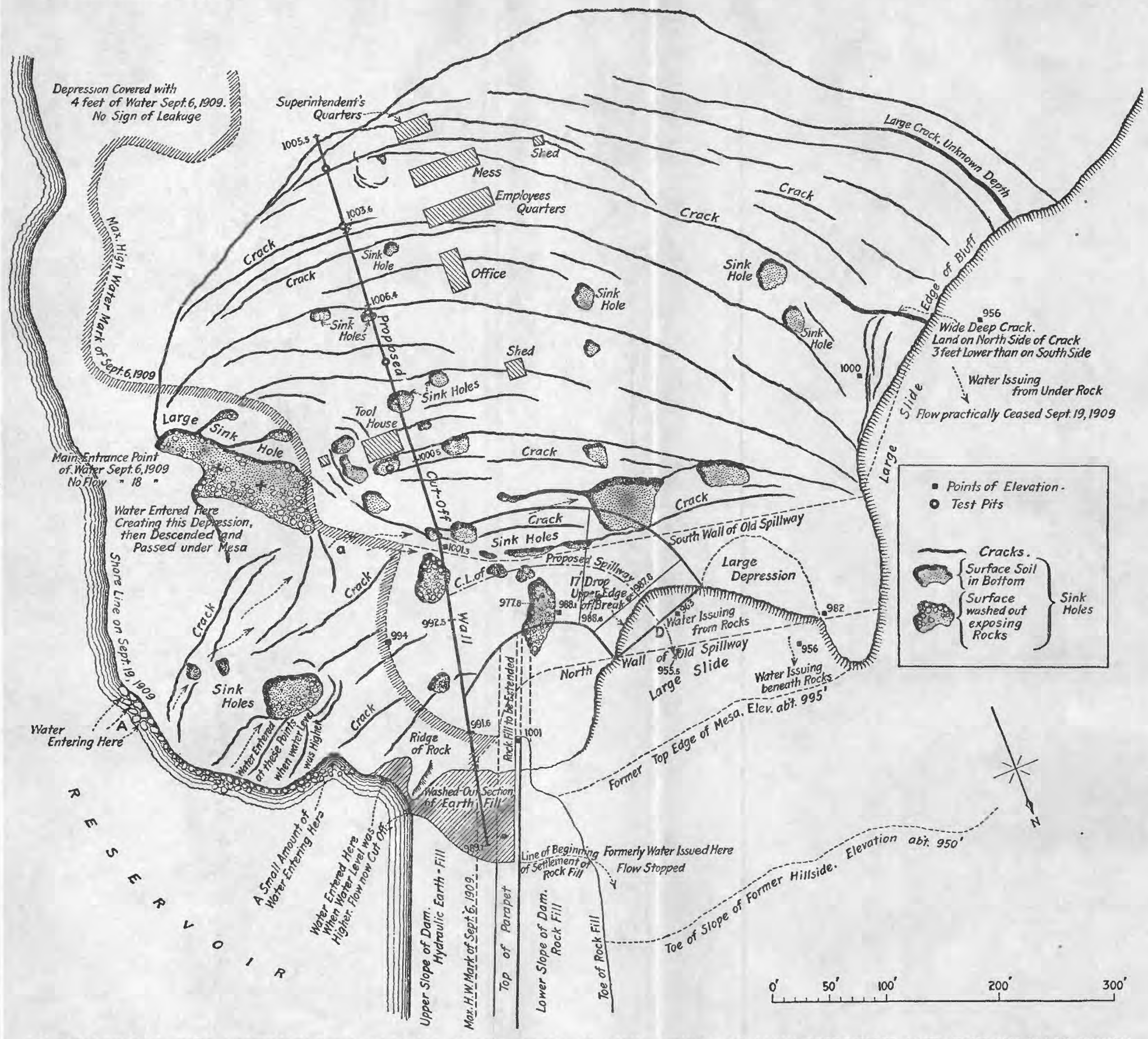

MAP OF SOUTH ZUÑI ABUTMENT OF DAM AT BLACK ROCK, N. MEX., SHOWING IIOW SPILLWAY AND END OF DAM WERE UNDERMINED 

The Zuñi Dam ${ }^{49}$ at Black Rock, N. Mex., is a rock fill with an earth blanket as the impervious part of the structure. At the dam site 30 feet of basalt lava rests on 40 feet of sand and clay, which rests on "blue clay" 20 feet below the stream grade. The lava caps flattopped "mesas" on both sides of the narrow canyon. The maximum height of the dam is 70 feet, and the length is 720 feet. The earth blanket is tied to the underlying "blue clay" by a trench filled with puddled clay. A spillway 100 feet wide and 10 feet deep had been excavated in the basalt on the south (left) abutment, which, as shown in Plate 1, had the relatively narrow width of 600 to 800 feet. On September 5, 1909, leaks appeared at the north (right) end of the dam amounting to 124 gallons a minute, and by the next morning this flow had increased to 467 gallons a minute, when it was stopped by blanketing the upstream slope with earth in bags. On the second day, September 6, muddy water was observed issuing from the south (left) end of the dam, and in spite of efforts to stop it the flow increased. The water was passing through cracks in the basalt and carrying away the fine sand that underlay the rock. As the flow increased slips occurred, and soon the spillway was undermined and large sections of the abutment and part of the dam slipped downstream and were carried away. The maximum amount of water discharged through the abutment and around the dam was 5,000 second-feet, but as the level of the reservoir lowered and remedial measures became effective the flow decreased. By September 10 the flow was moderate in amount, and by September 20 it had ceased. The extent of the damage to the abutment and the dam, as it appeared on September 20, is shown in Plate 1. Obviously the flow of water through the cracks in the basalt could take place on low gradients at sufficient velocity to entrain the sand, and even if the abutment had been wider it would have been menaced by this action. As the dam showed no leakage and was damaged only where it rested on the abutment, the failure serves as an excellent example of the fact that a narrow abutment of natural rock may be much weaker than an artificial mound of the same or smaller size.

Beemer ${ }^{48 a}$ has described succinctly a dam where anticipated leakage was reduced to innocuous quantities.

\section{SPIILWAYS}

Some method must be provided by which flood waters may pass a dam. Even if there are works for withdrawing stored water for use, additional waterways must be provided. The necessary capacity of spillways differs according to the size of the reservoir and the

40 Partial failure through undermining of the Zuñi Dam, N. Mex.: Eng. News, vol, 62, pp. 597-600, 10 figs., 1909 .

99a Beemer, J. A., Novel solution of Bridgeport Dam (Calif.) spillway problem; Eng. News-Record, vol. 98, pp. 108-110, 1927. 
regimen of the stream. There are also various forms of spillways. The so-called overfall type of dam is built so as to pass flood waters over its crest. Other dams have many gates within the body of the structure. The geologist is concerned with the erosive effect at the toe of an overfall dam and with spillways constructed at the side of the dam or at some distance from it. Engineering textbooks cover methods of protection for the toe of an overfall dam rather completely, and the geologist may be able to give very little vital help. At spillway sites, however, the geologist should consider the capacity of the rock to resist wear by falling water. If the site is on one of the abutments of the dam or at some low place in the rim of the reservoir underlain by clay, shale, soft sandstone, or similar material that is easily eroded, a concrete channel must ordinarily be built to convey the water into some natural drainage way. On the other hand, there may be so little water to overflow, or the possibility of a flood great enough to send water through the spillway may be so remote, or the grade may be so gentle that protection of the spillway may cost more than the benefit is worth. It may be cheaper to allow erosion to take place and repair the damage. This choice, however, is to be made on engineering and not on geologic grounds, and the engineer will base his decision on well-understood principles.

A serious problem arises if the only satisfactory place for the spillway is in a narrow abutment and the grade from the crest to the natural drainage way is steep. Here erosive action may weaken the abutment and endanger the structure. Massive igneous rocks will resist the erosive action of clear water, but many jointed consolidated rocks suffer severely. The massive sandstones at the Roosevelt Dam have been so much eroded by the water that falls nearly vertically from the mouths of the spillway tunnels that the cost of repairing the damage and of attempts to prevent further erosion has already reached a large sum. A single flood carried away 10,000 cubic yards of rock from the spillway of the Sweetwater Dam in California, ${ }^{50}$ requiring the construction of a concrete apron. At prospective dam. sites the geologic report should include a description of the rocks in the proposed spillways and estimates, however rough, of their resistance to erosion, on which the engineer, having in mind all the other factors of the problem, may base a judgment as to the necessity for paving the spillway channels.

At the Sherbourne Lakes Dam, in Montana, a concrete spillway built over one of the abutments was destroyed by soil creep and landsliding of the shale hill above it. Here the damage was caused by too deep a cut in an unstable hill slope. An adequate remedy is not

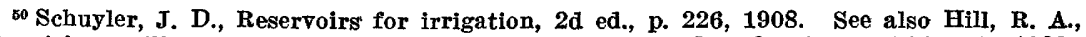
Repairing spillway to Gibraltar Dam: Eng. News-Record, vol. 89, pp. 798-801, 1922: Oram, H. P., Concentrated flow erodes rock below Wilson Dam: Idem, vol. 98, p. 190, 1927. 
immediately apparent, and the concrete has been replaced by timber which will form a temporary water channel until movement has ceased.

\section{TUNNELS AT DAM SITES}

Tunnels built in connection with dams may be divided by their purposes into three classes-(1) by-pass tunnels for diversion of the stream during construction of the dam, (2) outlet or diversion tunnels for drawing off water for use, (3) spillways. So far as their construction is concerned, these tunnels are like tunnels of any other kind. Only rarely would an abutment be so narrow or weak that the construction of a tunnel might dangerously impair it. The location of these tunnels is, however, subject to many ingenious arrangements by which one tunnel may be made to serve more than one purpose. If, therefore, one abutment has rock more favorable than the other for tunneling, or if construction at one level in preference to another is indicated by the geology, an additional factor is to be considered among the alternative possibilities. The geologist should, therefore, in close association with the engineer, consider all the possible locations for tunnels and describe the rocks with respect to tunneling operations.

\section{TUNNELS IN GENERAL}

The geology of tunnels involves problems more familiar to a geologist than other kinds of engineering geology, as his prime duty is to predict from the surface outcrops the position of the rocks at the grade line of the tunnel-that is, to construct a geologic cross section. The work should be of the accuracy demanded in mining operations. However, the same facilities as in mining are seldom available at tunnel sites, for there are generally no extensive excavations near by from which geologic data may be obtained. If, however, the cover is not too great, drilling should be done, and from even a few drill holes skillfully located fairly accurate predictions are possible.

Tunneling, however, is a highly complex art. The use of the proper methods and careful organization have a larger bearing on the cost than the difficulties encountered. For instance, tunnels of large diameter in earth requiring timber for support cost as much as tunnels of the same diameter in hard rock that must be drilled and shot down, but the type of men employed and the organization of the work are wholly different, so if hard rock is encountered unexpectedly in an earth tunnel the cost is much increased. On tunnels of large diameter, therefore, the nature of the material does not enter into the estimates of cost as much as into the plans for procedure. In tunnels of small diameter earth, even if it requires timber, is cheaper to penetrate than rock, and the resistance of the rock to $100370^{\circ}-29-3$ 
excavation is also a factor in cost. The ease of drilling, position of joints, effect of explosives, and size of pieces also materially affect the cost.

In tunnels of all sizes the characteristics of the rocks that produce disasters are of vital importance, and if they can be controlled the ultimate cost is reduced and human lives may be saved. "Swelling ground" is a name applied to the expansion of the wall rock of a tunnel. This expansion takes place because of the relief of pressure produced by the excavation itself, and this may be the sole cause. However, the absorption of moisture from the air and perhaps other conditions tend to weaken rock newly exposed in the walls of tunnels and cause it to expand. The action is most likely to occur in shale and in the claylike decomposition products of igneous rocks. When such material is encountered the timbers are squeezed and broken, tunnel alinement and shape are lost, and other difficulties arise. As yet the causes of swelling ground are imperfectly known, but the geologist should note that bentonite or any of the minerals characteristic of bentonite ${ }^{51}$ are warning signals, and if they occur in material quantity, swelling ground should be anticipated.

Wet ground or sudden rushes of water are expensive or dangerous, or both, and to drive a tunnel below ground-water level in unconsolidated sand, gravel, or clay ordinarily requires complicated apparatus and the use of compressed air to hold out the water. If such wet ground is encountered suddenly, as where a buried river channel crosses the tunnel line, disaster results. Open channels in the crevices of igneous rocks or caverns in limestone produce similar floods. Long tunnels under deep cover may encounter hot springs or sudden inrushes of water from overlying ponds or streams..$^{52}$ In some rocks inflow of explosive or noxious gases may occur.

Earth temperatures in tunnels with a thick cover may be high and add to the difficulty of the work. In some localities, as on the Owyhee project, Oregon, observations on the local earth-temperature gradient are available, and the temperature can be closely predicted. In other localities the geologist must, after a review of all the facts available, estimate the probable earth temperature, or if test holes are drilled he may make direct observations.

Fortunately a detailed account of the geologic work by Berkey, ${ }^{53}$ which was checked against the results shown by construction, has been published and affords a fairly complete manual for geologic work on tunnels. Many pertinent data are also available in De

${ }_{51}$ Ross, C. S., and Shannon, E. V., The minerals of bentonite and related clays and their physical properties: Am. Ceramic Soc. Jour., vol. 9, pp. 77-96, 1926.

${ }^{62}$ Kusida, K., Difficulties in long tunnel for Japanese railways: Eng. News-Record, vol. 95, pp. $336-338,1925$.

ss Berkey, C. P., Geology of the New York City (Catskill) aqueduct: N. Y. State Mus. Bull. 146, 283 pp., 1911. 
Launay's textbook,,$^{54}$ and Ries and Watson ${ }^{55}$ have given a good introduction to the subject.

\section{QUALIFICATIONS OF, THE GEOLOGIST}

The geologist's attitude toward his work and his personality are perhaps larger factors in engineering geology than in other kinds of geologic work. He must inspire confidence in his conclusions, yet he is subject to a rigid verification in which the errors that he may make will be startlingly apparent.

In much geologic work the risk of error is lightly considered. Only the reputation and self-esteem of the geologist are at stake, and he feels that if he is right on the main issue the workers of the future will bring out the whole truth and deal kindly with his minor errors. Geologic work done for engineering projects, however, often concerns the expenditure of large sums of money, and the geologist should feel this responsibility as well as a sense of duty to the engineer whose reputation is also at stake. He should be scrupulously frank in laying before the engineer the nature of the evidence and the basis on which a conclusion has been reached. The science of geology is as yet only partly developed, and in only a few areas has the general geologic structure and history been worked out with the thoroughness that is even now possible. Thus the geologist has an imperfect instrument to work with and may find that in the particular spots selected for engineering structures it is impossible to get adequate evidence. He should therefore assist the engineer in forming a judgment as to the validity of the conclusions indicated by the geologic work. In a certain investigation, for instance, it was proposed to carry a canal across a valley by creating a lake into which the canal would discharge at one end and be led off at the other. A siphon crossing was also possible but required nearly 2 miles more of canal. The cost of the two alternatives was nearly the same, but the lake would afford regulatory storage, which would be an advantage in operation. The abutments of the proposed dam were narrow interfluves between tributary streams and by geologic inference, for there were very few outcrops, were thought to consist of 30 feet of sand resting on clay and therefore likely to leak. By locating the dam half a mile upstream, wider abutments in what appeared to be similar material could be obtained, but greater yardage in the dam and an additional half a mile of canal were required. Although the geologic inference rested on an inadequate basis the engineer decided to test this new site by drilling, which confirmed the prediction as to the composition of the abutment. The new data indicated that with proper precautions a safe structure could be built where the 
abutments were wide, and the engineer abandoned the original site and adopted the new site with its slight additional cost.

As all phases of geologic science may need to be used, the geologist should be broadly trained. Obviously familiarity with the local geology or with geology of the same type is advantageous, but given time a well-trained geologist can master these details, and it is perhaps of greater importance that he should have some knowledge of

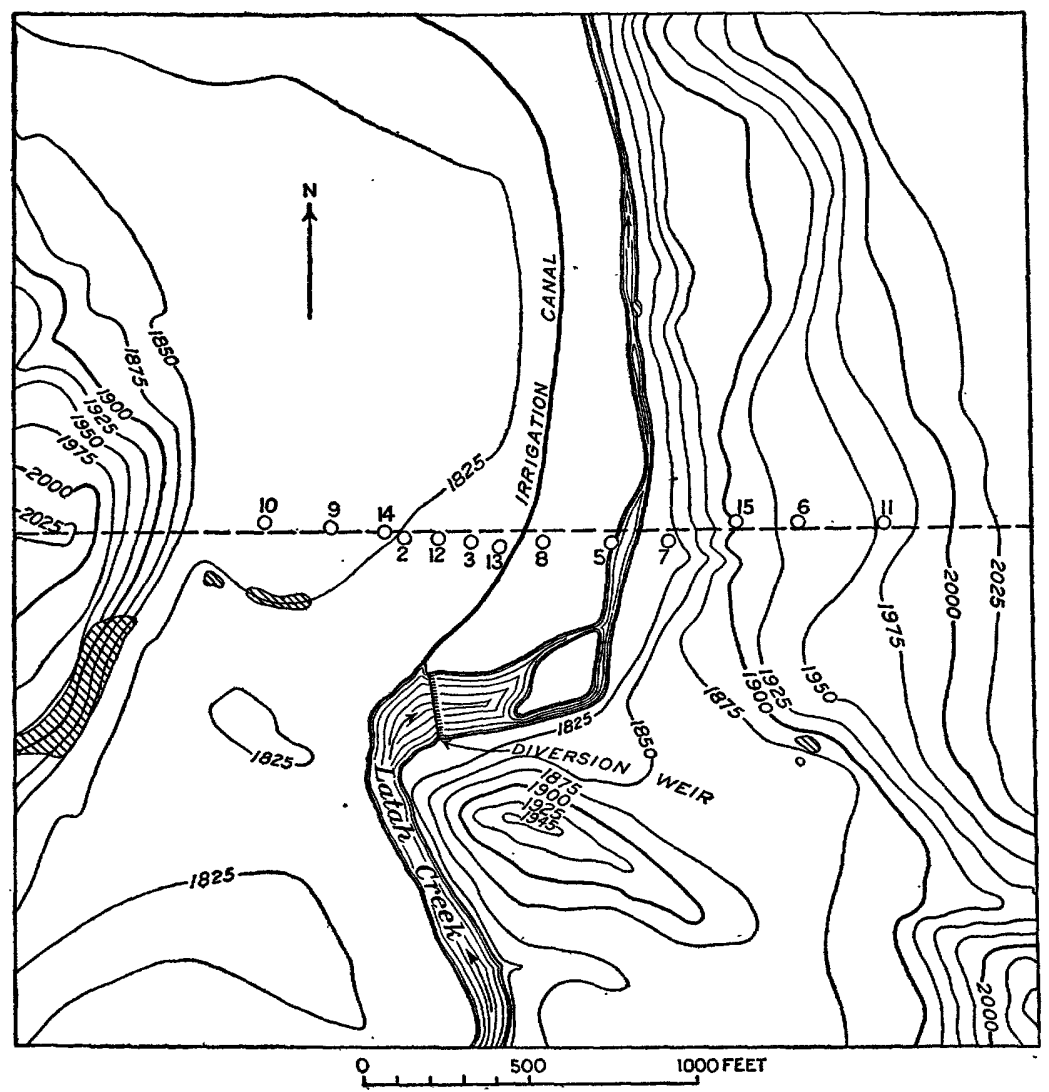

Fradra 2.-Map showing geology of Latah Creek dam site, Columbia Basin irrigation project, Washington, as interpreted from outcrops and test wells. Diagonal shading indicates outerops of basalt; the rest of the area is occupied by sand and gravel. Numbered circles indicate drill holes; dashed line, center of proposed dam. See also Figure $\mathbf{3}$

engineering problems and methods. Above all things, however, the geologist should not allow himself to be diverted to geologic problems, however interesting, that are not involved in the question before him.

A reasonable success in prediction is all that may be expected. What may be deemed to be an unusually close prediction is illustrated in Figure 3. On the map of the site (fig. 2) are shown the 

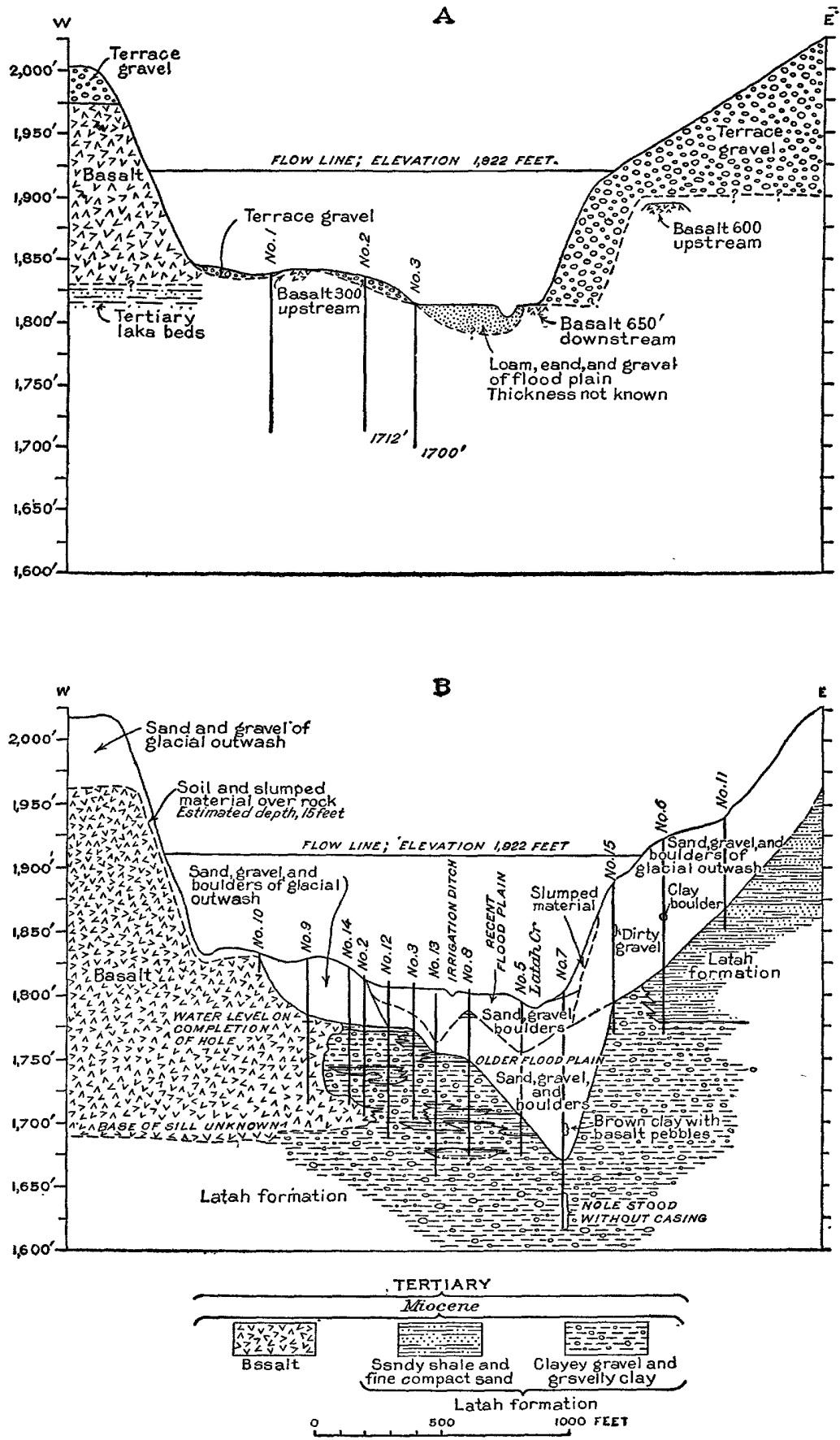

Figurm 3.- Geologic cross sections of Latah Creek dam site, Columbia Basin irrigation project, Washington. A, Showing known and inferred relations; B, based on completed examination and results of test drill holes. 
outcrops of basalt, and the only other visible materials were sand and gravel of the flood plain and the terraces. In the cross section A, Figure 3, on the center line of the proposed dam is the prediction based on a general study of the geology, as the drill holes 1, 2, and 3 , already put in, could not be interpreted. In B, Figure 3, is given the cross section as constructed after the drilling of 13 test holes. The first three holes could then be interpreted, and the conjectured cross section was confirmed except for the depth of the stream channel and the thickness of the sand in the terrace on the right abutment.

\section{RELATIONS OF GEOLOGIST AND ENGINEER}

The relations of engineer and geologist should be inspired by mutual confidence. If the engineer feels that the geologist is merely a crack-brained theorist, and the geologist feels that the engineer is merely a stolid-minded fellow who thinks of nothing but figures, little good will come of their association. With mutual consideration, however, they will, by the junction of two divergent points of view, come nearer to the truth of the matter together than by the same amount of independent work.

In general, the geologist bears to an investigation or to a project under construction the relation of a consultant. He should be untrammeled in his survey, but he is responsible to the engineer in charge, and his activities should be so adjusted as to furnish information at the time when it is needed in the engineering work and not necessarily according to a program that will most logically develop the local geologic problems.

On the engineer falls the responsibility for the design of structures and usually also for the cost of the investigation. Unless he confides in the geologist his ideas and tentative decisions as they are formed, the geologic work may be directed into unprofitable fields.

In a certain large project it was proposed to build a dam with many gates across a strait, and the first idea set forth was that this dam should consist of a series of concrete caissons. The water body was about 6,000 feet wide and in places 125 feet deep and had a soft bottom. The prediction of geologic conditions under this extensive body of water was a task to daunt the boldest geologist. However, the engineer in charge and the geologist held a conference, and the engineer proposed a plan to build the structures on dry land on one side of the strait, excavate deep channels to them, and use the material so gained to block the original waterway. As there was excess yardage to compensate for settlement, however large, it is obvious that the geology of the under-water area was of little moment. Had the geologist not been informed of this ingenious device, he would have 
spent much time in an almost hopeless effort to predict the distribution of rocks in this water-covered area.

The geologist must, therefore, have the confidence of the engineer, but it does not follow that the engineer is bound by the opinions of the geologist, nor can he shift to the geologist the final responsibility for success or failure. If there is doubt in his mind as to the findings of the geologist, he should bring in another or test these findings by additional test pits and borings. At best the real economy in the use of geologists is in reducing the number of actual tests.

In general, the association of geologists with engineering investigations and projects has its principal advantage in directing the attention of the engineer to the detailed characteristics of the rocks and soils with which he must contend. With the accurate description of these materials supplied to him by the geologist and with reasonably accurate predictions of their form and underground extent, he is free to exercise his ingenuity in overcoming the difficulties of construction. To the geologist comes the satisfaction of putting his effort on works of magnitude that will benefit the communities affected, although he will probably report on many more schemes that will never be built than on feasible projects that he will live to see carried out. His best reward comes, however, in the rigid testing of his observations and inferences by means of borings and excavations. Many of his results may have only local value, but others will be of general utility and will be incorporated into the body of geologic knowledge. The principles of the application of geology to the problems of civil engineering are as yet incompletely developed, as indicated by this short sketch, and this field lies open for cultivation by the willing and experienced worker.

\section{BIBLIOGRAPHY}

An annotated list of papers on the geology of reservoir, dam, and tunnel sites in the United States is given below:

Clarke, J. M., The geologic conditions at the site of the proposed dam and storage reservoir on the Genesee River at Portage: New York State Eng. and Surveyor, Genesee River Storage Surveys, pp. 106-122, 1897, also New York State Eng. and Surveyor Ann. Rept. for 1896, pp. 730-746, 1897.

Crosby, W. O., Geology of the Wachusett Dam and Wachusett Aqueduct tunnel of the Metropolitan waterworks in the vicinity of Clinton, Mass. : Tech. Quart., vol. 12, pp. 68-96, 1899. Fine presentation of detailed geologic results obtained in connection with a great engineering undertaking that was successfully completed.

Crosby, W. O., Geological history of the Nashua Valley [Mass.] during the Tertiary and Quaternary periods: Tech. Quart., vol. 12, pp. 288-324, 189. Gives more applied geology than in previous paper, including map of Wachusett Reservoir, and discusses buried channels with respect to water-tightness. 
Crosby, W. O., Notes on the geology of the sites of the proposed dams in the valleys of the Housatonic and Tenmile Rivers: Tech. Quart., vol. 13, pp. 120127, 1900. Reports favorably on two dam sites-one in gneiss and the other in limestone.

Gowen, C. S., The foundations of the new Croton Dam: Am. Soc. Civil Eng. Trans., vol. 43, pp. 468-542; discussion, pp. 543-565, 1900. Contains elaborate description of test borings and of conditions found in excavation of foundation composed largely of limestone; contains letter on caves in limestone by J. F. Kemp, pp. 498-499, Describes elaborate campaign of grouting with clay.

Taylor, T. U., The Austin Dam [Tex.] : U. S. Geol. Survey Water-Supply Paper 40, 52 pp., 16 pls., 12 figs., 1900 . Describes minutely construction of dam, silting of reservoir, and failure of dam. Valuable for account of influence of geology on construction and failure.

Newell, F. H., Report of progress of stream measurements for the calendar year 1899: U. S. Geol. Survey Twenty-first Ann. Rept., pt. 4, pp. 265-269, 1901. Brief description of geology at White Rock Canyon dam site, on Rio Grande. Abutments of the dam consist of coarse unconsolidated gravel overlain by basalt. This unfavorable geologic condition and small storage capacity have so far prevented any attempt to build at this site. (See Lee, 1907.)

Crosby, W. O., A study of hard-packed sand and gravel: Tech. Quart., vol. 15, pp. 260-264, 1902. Attributes cause of hard-packed sand and gravel found in test drill holes to moist condition, neither wet nor dry.

Crosby, W. O., A study of the geology of the Charles River estuary and the formation of Boston Harbor, Mass. : Report of the committee on Charles River Dam, appendix 7, pp. 345-369, 2 maps, 1 fig., Boston, 1903. Analyzes physiographic history of the region and comes to conclusion that the channel of Charles River and its extension in Boston Harbor are not kept open by tidal scour, and hence the proposed reduction in the volume of the tidal prism will not damage navigation. Contains detailed information on relation of geology to structures, and geologic maps with contours of the bedrock surface.

Crosby, W. O., A study of the geology of the Charles River estuary and Boston Harbor [Mass.] : Tech. Quart., vol. 16, pp. 64-92, 1903. Omits much engineering geology and contains slightly more physiographic material than original report.

Crosby, W. O., Geology of the Weston Aqueduct of the Metropolitan waterworks in Southboro, Framingham, Wayland, and Weston, Mass.: Tech. Quart., vol. 17, pp. 101-116, 1904. Describes foundations of Sudbury Dam and geology of five tunnels. Gives few data on relation of geologic conditions to difficulties in construction.

Hamlin, Homer, Water resources of the Salinas Valley, Calif.: U. S. Geol. Survey Water-Supply Paper 89, 91 pp., 12 pls., 30 figs., 1904. Describes many reservoirs and dams with much geologic information and shows skill in the application of geology to engineering.

Hobbs, W. H., The configuration of the rock floor of Greater New York: U. S. Geol. Survey Bull. 270,96 pp., 5 pls. (maps and sections), 6 figs., 1905. Compiled data on depth to bedrock and overlying material useful in construction. (See Berkey and Healy, 1912.)

Lee, W. T., Geology and water resources of Owens Valley, Calif.: U. S. Geol. Survey Water-Supply Paper 181, pp. 15-17, 1906; abstract, U. S. Reclamation Service Third Ann. Rept, 2d ed., p. 202, 1905. Discusses Long Valley Reservoir, possibility of leakage, of seismic disturbances, and character of local building materials.

Lee, W. T., Gypsum beds and water storage in the Pecos Valley of New Mexico (abstract) : Science, new ser., vol. 23, p. 306, 1906. Discusses cavernous 
condition of rocks near Carlsbad due to solution of gypsum and salt with relation to leakage of McMillan Reservoir.

Fisher, C. A., Preliminary report on the geology and underground waters of the Roswell artesian area, N. Mex.: U. S. Geol. Survey Water-Supply Paper 158, p. 27, 1906. Describes Hondo Reservoir as high natural depression on divide between Blackwater Arroyo and Hondo River. Surface rock massive blue limestone, underlain by alternate layers of gypsum and red and yellow clay. "The bedding was originally uniform, but surface waters have dissolved the gypsum, causing a settling of the beds in the bottom of the reservoir and considerable local distortion around the rim." Says that diamond-drill holes were sunk and gives $\log$ of one to 91.8 feet showing cavities, loose rock, and gypsum.

Lee, W. T., Water resources of the Rio Grande Valley and their development: U. S. Geol. Survey Water-Supply Paper,188, pp. 25-30, 1907. Describes proposed reservoir sites-International Reservoir, Engle (now known, as Elephant Butte) Reservoir, San Acacia Reservoir, San Felipe Reservoir, Espanola Reservoir (White Rock Canyon, see Newell, 1901) -all on Rio Grande in New Mexico.

Berkey, C. P., Quality of bluestone in vicinity of Ashokan Dam [Kingston, N. Y.] : School of Mines Quart., vol. 29, pp. 149-158, 1908.

Lee, W. T., Geologic reconnaissance of a part of western Arizona : U. S. Geol. Survey Bull. 352, pp. 37-49, 1908. Discusses reservoirs and dam sites on Colorado River, using maps prepared by U. S. Reclamation Service and data gained in drilling dam sites.

Smith, L. S., The water powers of Wisconsin: Wisconsin Geol. and Nat. Hist. Survey Bull. 20, pp. 354, 1908. Contains sketch of physical geography of State, by Samuel Weidman, pp. 6-20, and short general description of geology and topography of each drainage system, also scattered remarks on nature of rock at dam sites.

Berkey, C. P., Geology of the New York City (Catskill) Aqueduct: New York State Mus. Bull. 146, 283 pp., 38 pls. including maps, 39 figs., 1911. Gives details of geologic studies of foundations for Ashokan Dam, location of aqueduct, numerous tunnels, and Hudson River crossing. Most complete presentation of the geologic work with many colored plates. Later papers valuable for data on construction and attitude of engineers toward work.

Berkey, C. P., Geological features of the city tunnel of the Catskill Aqueduct: New York City Board of Water Supply Rept. on the City Tunnel, pp. 115-186, map, 1912; Columbia Univ. Geol. Dept. Contr., vol. 23, No. 11. An original report with detailed recommendations on specific questions pertinent to engineering problems, geology of Silver Lake Reservoir (pp. 178-183), and colored geologic map of New York City.

Berkey, C. P., and Healy, J. R., The geology of New York City and its relations to engineering problems (with discussion): Municipal Eng. City of New York Proc. for 1911, pp. 5-39, 1912. Comprehensive description of local rocks with respect to engineering problems. (See Hobbs, 1905.)

Kemp, J. F., Geological problems presented by the Catskill Aqueduct of the City of New York : Canadian Min. Inst. Quart. Bull. 16, pp. 3-9, 1911; Canadian Min. Inst. Jour., vol. 14, pp. 472-478, 1912. A general account of geologic -work in Catskill Aqueduct.

Kemp, J. F., The Storm King crossing of the Hudson River by the new Catskill Aqueduct of New York City: Am. Jour. Sci., 4th ser., vol. 34, pp. 1-11, 1912. Gives geologic data obtained by drilling at this locality.

Martel, E. A., Sur le déplacement de sources thermales à la Roosevelt Dam, Ariz.: Compt. Rend., vo1. 155, pp. 1568-1570, 1912. Describes thermal springs that have broken out below Roosevelt Dam since construction and rapid erosion of rock in spillways. 
Purdue, A. H., Geology and engineering: Resources of Tennessee, vol. 3, pp. 105-109, 1913. Describes failure of two concrete reservoirs: City of Nashville, Tenn., failed Nov. 5, 1912, after life of 23 years; Johnson City, Tenn., failed Jan. 10, 1913, when first filled.

Fuller, M. L., Dam and embankment failures in 1912, discussion of the types of structures and causes of destruction : Eng. News-Record, vol. 67, pp. 426-428, 1913. Attributes 61 per cent of failures for this year to neglect of the geologic factor.

Anonymous, Accident at Dam 26 on Ohio River : Eng. News-Record, vol. 67, pp. 542-544, 1913 . Quotes letter from U. S. Geological Survey giving results of petrographic examination of fragment of shale procured after failure from foundation of the dam.

Crosby, W. O., Buried gorge of the Hudson River and geologic relations of Hudson syphon of the Catskill Aqueduct (abstract) : Geol. Soc. America Bull., vol. 25, pp. 89-90, 1914. Deals with geologic problems in light of data from borings.

Harza, L. F., Columbia River power project near The Dalles, Oreg. : U. S. Bur Reclamation and State of Oregon Coop. Rept., San Francisco, 1914. Description of geology of site, pp. 8, 21-25.

Fowler, C. E., Leakage from Cedar Lake Reservoir, Seattle [Wash.] Water Supply: Eng. News, vol. 73, pp. 112-115, 1915. Account of failure by leakage, with maps, based on personal knowledge and reports of geologists.

Rands, H. A., Grouted cut-off for the Estacada Dam [Oreg.] : Am. Soc. Civi] Eng. Trans., vol. 78, pp. 447-482; discussion, pp. 483-546, 1915 . Emphasizes difficulties in grouting in volcanic breccia. Geologic report by J. S. Diller quoted on pp. $449,484-485$.

Collier, A. J., Geology of Dayville reservoir and dam site, in Whistler, J. T., and Lewis, J. H., John Day project, irrigation and drainage, pp. 90-93, U. S. Reclamation Service and State of Oregon, 1916. Detailed report based on field work and inspection of samples.

Williams, I. S., Geology of Clarno dam site: Idem, pp. 82-88. Detailed report based on field work by a geologist familiar with local rocks.

Mead, D. W., Report on the dam and water-power development at Austin, Tex., 205 pp. privately printed, 1917 . See appendixes $1-5$, pp. 40-143, for complete history of old and new dams, geologic conditions at site, results, and bibliography of 55 references.

Scheidenhelm, F. W., The reconstruction of the Stony River Dam [W. Va.]: Am. Soc. Civil Eng. Trans., vol. 81, pp. 907-1023; discussion, pp. 1024-1100, 5 pls., 2 photos., 1917. Describes geologic conditions at dam site minutely and shows effect on failure of original dam and on methods of reconstruction.

Atwood, W. W., Relation of landslides and glacial deposits to reservoir sites in the San Juan Mountains, Colo.: U. S. Geol. Survey Bull. 685, 38 pp., 8 pls. 17 figs., 1918. Comprehensive account of cause of reservoir basins; contains detailed discussion with maps of reservoirs and dams, and data on leakage through cracks in rocks and through landslide masses.

Davis, A. P., Why some irrigation canals and reservoirs leak: Eng. NewsRecord, vol. 8, pp. 663-665, 1918. Discusses canals on projects at Flathead, Mont., Grand Valley, Colo., and Spanish Fork, Utah, the Jerome and Deer Flat Reservoirs in Idaho and the McMillan and Hondo Reservoirs in New Mexico.

Hamlin, Homer, Report on geological examination of Iron Canyon dam and reservoir site, Calif., in Gault, H. J., and McClure, W. F., Iron Canyon project, Calif., appendix 1, pp. 45-59, 9 pls., U. S. Bur. Reclamation, 1921. Precise and 
valuable study of alternate dam sites in close association with an engineer, supplemented by test drilling and leading to choice of a dam site not before considered.

Lawson, A. C., Report on geology of Iron Canyon [Calif.] : Idem, appendix 3, pp. 73-76. Preliminary report on same project as discussed by Hamlin.

George, R. D., Notes on the geology of the line of the proposed Moffat Tunnel, Colorado Geol. Survey, July, 1922. Preliminary study of tunnel. Value of geologic predictions not yet recorded.

Willis, Bailey, Geology of the Colorado River Basin, with reference to engineering problems: Science, new ser., vol. 56, pp. 177-182, 1922. Alarming statement of danger of earth movement on old fault lines. Publication of this article led to intensive geologic work and elaborate manuscript report by F. L. Ransome. Part of the evidence gathered by Ransome has been pụblished. (See Ransome, 1923.)

Berkey, O. P., and Sanborn, J. F., Engineering geology of the Catskill Aqueduct: Am. Soc. Civil Eng. Trans., vol. 86, pp. 1-67, 3 pls., 17 figs.; discussion, pp. 68-91, 1923. Complete review of geologic work done and methods and principles used in applying geology to location, and construction of a great engineering undertaking. Illuminating discussion by many civil engineers.

Bryan, Kirk, Discussion [on geologic setting of rock-fill dam at. Lees Ferry, Ariz.] : Am. Soc. Civil Eng. Trans., vol. 86, pp. 228-240, 1923. Describes geologic structure, lithology, and jointing of rocks at Lees Ferry, with respect to building of a high dam across Colorado River and driving of several tunnels. Describes materials available for construction.

Leighton, M. M., Geology and the Decatur dam and reservoir project: Eng. News-Record, vol. 91, pp. 264-266, 1923. Glacial formation explains why sheet piling could not be driven to intended depths-water-tightness assured. Describes glacial formations at site and geologic difficulties encountered in construction.

Leighton, M. M., The glacial history of the Sangamon River Valley at Decatur [IIl.] and its hearing on the reservoir project: Illinois State Acad. Sci. Trans., vol. 14, pp. 213-218, 1 pl., 1922.

Ransome, F. L., Ancient high-level potholes near the Colorado River (abstract) : Science, new ser., vol. 57, p. 593, 1923. Black Canyon of Colorado River cut in relatively late geologic time; potholes $\mathbf{9 0 0}$ feet above river mark ancient channel. These potholes cut into faults (and fault gouges) ; hence no movement on faults during period necessary to cut canyon 900 feet deep.

Patton, L. T., Geology and the locations of dams in west Texas: Econ. Geology, vol. 19 , pp. $756-761,1924$. Discusses the relation of suitable sites for dams to the distribution of certain roek formations. Specific dam sites and reservoirs not described.

Lee, W. T., Erosion by solution and fill: U. S. Geol. Survey Bull. 760, pp. 115-116, 1925. Mentions briefiy McMillan Reservoir, proposed No. 3 Reservoir, and Hondo Reservoir, in New Mexico, in relation to open cavities and to leakage due to solution of gypsum, salt, etc.

Deeds, J. F., and White, W. N., Water power and irrigation in the Madison River Basin, Mont.: U. S. Geol. Survey Water-Supply Paper 560, pp. 6-8, 1925. Brief discussion of geology of dam site in Madison River; also geology of the area with respect to building dams, by G. R. Mansfield.

Moore, R. C., Geologic report on the inner gorge of the Grand Canyon of Colorado River: U. S. Geol. Survey Water-Supply Paper 556, pp. 125-171, 1925. Describes geology with respect to many dam sites; much geologic matter by F. C. LaRue in body of report. 
Parsons, H. deB., Sherman Island dam and power house: Am. Soc. Civil Eng. Trans., vol. 88, pp. 1257-1292 ; discussion, pp. 1293-1328, 1925. This is a multiple-arch dam on sand foundation with rock abutments. Geology of the site on pp. 1261-1263 rewritten from report by C. P. Berkey.

Stearns, H. T., Porosity of reservoir prevents water storage [Malad Reservoir, Idaho] : Eng. News-Record, vol. 96, p. 561, April 8, 1926. Staff article abstracting manuscript report by Stearns. Describes leakage in reservoir through openings in limestone in a small area in the floor, as determined by contour map of water table, and advocates pressure grouting to fill cavities.

Meinzer, O. E., Renick, B. C., and Bryan, Kirk, Geology of No. 3 reservoir site, Carlsbad irrigation project, N. Mex., with respect to water-tightness: U. S. Geol. Survey Water-Supply Paper 580, pp. 1-39, 1926. Describes in detail geologic structure and hydrologic conditions in cavernous rocks consisting of limestone, gypsum, and shale. Test wells showed water table far below floor of reservoir in its lower part, where gypsum crops out, and opinion is expressed that excessive leakage will ensue if dam is built to impound water. Contains data on near-by McMillan and Avalon Reservoirs. (See Lee, 1906, 1925, and Davis, 1918.)

Lawson, A. C., Geology of Lancha Plana dam site [Calif.] : East Bay Municipal Utility District Ann. Rept. for 1925, pp. 15-16, Oakland, 1926. Describes geology at three alternative sites on Mokelumne River.

Dreyer, W., Volcanic formations govern design in Pit River No. 3 hydroelectric development [Calif.] : Eng. News-Record, vol. 96, pp. 144-149, 1926. Volcanic plateaus absorb precipitation which emerges in canyons to form spring-fed rivers of uniform flow. Geologic cross section at dam site determined by drilling and effect on construction shown. Data on grouting.

Hanna, F. W., Designing a high storage dam for the Mokelumne project: Eng. News-Record, vol. 100, pp. 444-446, 1928. Describes results of exploration of site reported on by Lawson, 1926, and change of plans as a result of finding unsound rock not disclosed by geologic examination.

Leighton, M. M., Modern geology and its contribution to engineering: Western Soc. Eng. Jour., vol. 28, pp. 491-506, 5 figs., 1923.

Carman, J. E., discussion of paper by Gregory, Hoover, and Cornell on "The O'Shaughnessy Dam and Reservoir [Ohio]": Am. Soc. Civil Eng. Proc., vol. 54, pp. 1325-1327, 1928. Gives detailed section of rocks exposed by excavation for the dam.

Wentworth, C. K., Examination of dam sites in the Tennessee River Basin [abstract] : Geol. Soc. America Bull., vol. 39, pp. 204-205, 1928.

Smith, W. D., Geological suite from eastern Oregon, pt. 2, The Owyhee project [abstract] : Geol. Śoc. America Bull., vol. 39, p. 169, 1928.

Since this report was prepared the disastrous failure of the St. Francis Dam, in California, has occurred. News reports of the failure and descriptions of the site and of various investigations will be found in the Engineering News-Record, vol. 100, pp. 456, 466-472, $517-518,526,605,639$, and 675. More strictly geologic reports are as follows:

Forbes, Hyde, Geological foundations at the St. Francis dam site: Eng. NewsRecord, vol. 100, pp. 596-597, 1928.

Longwell, C. R., Lessons from the St. Francis Dam: Science, new ser., vol. 68, pp. 36-37, 1928.

Ransome, F. L., Geology of the St. Francis dam site: Econ. Geology, vol. 23, pp. $553-563,1928$. 


\title{
GEOLOGY OF THE OWYHEE IRRIGATION PROJECT, OREGON
}

\author{
By Kirk Bryan
}

\section{OUTLINE}

For many years irrigation by simple diversion has been practiced on the low alluvial lands along Owyhee and Malheur Rivers near their junction with Snake River, in southeastern Oregon. (See fig. 4.) During this period the good soil of higher areas-the socalled bench lands, which lie along both rivers and the adjacent western"slopes of the Snake River Valley-has tempted ambitious persons to propose various schemes by which water might be led on to these fertile lands. Small areas have been put under cultivation by pumping water from Snake River, and others in the Malheur Basin by high-level diversion. The major portion of this land, however, requires long canals and diversion from the upper courses of the rivers, and the scale of such work calls for governmental backing. It would be profitless to review all the schemes proposed for the irrigation of these lands, as one has come from each investigation of the problem, differing from the others both in source of water supply and in the position and area of the lands to be irrigated.

As now outlined, the Owyhee project consists of a combined storage and diversion dam at Hole in the Ground, on Owyhee River, and a conduit through rough country involving tunnels and siphons. The conduit divides not far from the reservoir, one branch swinging south to supply the bench lands along Snake River Valley south of the junction with Owyhee River and one branch going north, crossing Owyhee and Malheur Rivers by inverted siphons, to irrigate the discontinuous bench lands adjacent to the lower courses of these streams. The project involves the construction of a dam 390 feet high, at least 14.7 miles of tunnel, and more than 150 miles of main canal. The tentative estimated cost in 1924 was $\$ 16,800,000$ to be divided as follows: $\$ 25$ an acre for lands now irrigated by the Owyhee ditch, $\$ 117$ an acre for lands now served by pumps, and $\$ 137$ an acre for newly irrigated lands. The settlement of 1,400 to 1,600 families will be required to bring the undeveloped land into use. The 


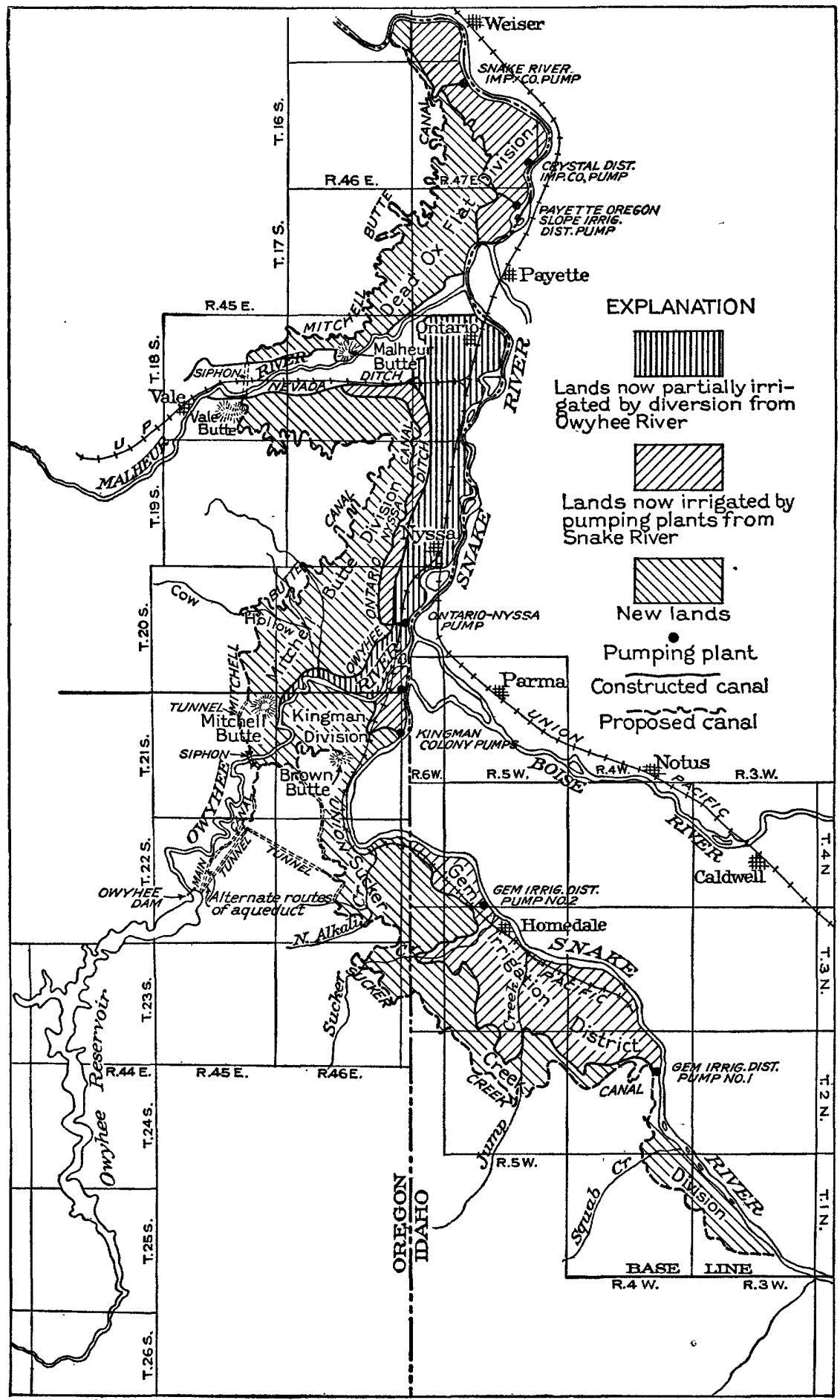

FigUR⿴ 4.-Sketch map showing location of Owyhee irrigation project, Oregon 
importance of the project in cost and in prospective benefit to the region is large. The problems of engineering, agriculture, and finance are difficult and interesting. These features are not discussed in this report, which is restricted to the applied geology of the larger engineering structures.

\section{FIELD WORK}

At the request of $\mathrm{C}$. $\mathrm{E}$. Weymouth, then chief engineer of the Bureau of Reclamation, I was engaged in field work for eight days, beginning November 26, 1923. One day of this time I spent at the Duncan reservoir site and dam site, three and one-half days at the Diversion reservoir site and dam site, and the remainder of the time in travel and conference. A report on this work, dated December 14, 1923, was made, in which additional field work was recommended. Pursuant to correspondence between the chief engineer, Bureau of Reclamation, and the chief hydraulic engineer, Geological Survey, I arrived in Boise, Idaho, October 1, 1924, and the next day had a conference with J. B. Bond, superintendent of the Boise irrigation project, and R. N. Newell, in charge of field surveys. I arrived at the Bureau of Reclamation camp on the 4th. The following 18 days was spent in field work, and during part of that time I was assisted by B. Coleman Renick, who arrived October 11. Mr. Bond placed an automobile at my disposal. Mr. Newell gave me the facilities of his camp and provided saddle horses. His courtesy and thoughtfulness expedited the work. R. E. Gossett and S. B. Tierney, drill foreman, and other employees of the Bureau of Reclamation were most helpful. The Duncan reservoir site was not reinvestigated in 1924 , and as this site is no longer under consideration the statement of December 14, 1923, is not repeated. The results of the work of Mr. Renick on the petrology of the rocks and the order and thickness of the formations are incorporated herein, largely in the phraseology of a manuscript report on these subjects prepared by him. The new formation names Grassy Mountain basalt, Blackjack basalt, and Owyhee basalt, proposed in that manuscript, are herein adopted.

A summary of later geologic work by Warren D. Smith and F. L. Ransome is appended in order to bring up to date the geologic information on the structure of this project.

\section{OW YHEE RIVER}

Owyhee River rises in Nevada and flows north and northwest through Idaho into Oregon and thence north to a confluence with Snake River at the Oregon-Idaho boundary. The river and its tributaries flow for most of their courses in canyons cut in the extensive plateaus of southeastern Oregon, a region of deficient rainfall de- 
voted largely to the raising of sheep and cattle. Much of the region is an elevated plateau standing from 3,500 to 4,500 feet above sea level. In Nevada high ranges rise above this level, but in Oregon there are, with the exception of the Stein Mountains, which form a considerable range, only small groups of scattered hills. Most of these hills are, however, dignified by the name of mountains. Parts of the plateau are covered with basalt flows that spread from craters still visible. These flows range in thickness from 25 to 200 feet, and this thin veneer conceals over large areas the complex structure of the underlying rocks.

In general, however, the surface of the plateau appears to be an ancient erosion surface. Rocks of unequal resistance have been more or less reduced to a common level, but successive outpourings of lava and possibly unequal uplift have so complicated the evidence that it may easily be that the surface of the plateau was formed over a long period and in more than one partial erosion cycle.

In this plateau Owyhee River has cut a gorge which is about 500 feet deep near Duncan Ferry and about 2,000 feet deep a few miles from the mouth of the river. (See pl. 2.) In areas of soft rock the gorge widens to a broad valley, and the bottom lands are farmed. In the harder rocks the gorge is narrow and may for miles be too narrow for a road beside the river. The dam sites that were investigated lie in the narrow reaches of the gorge, and the reservoir sites are the broader parts of the valley immediately upstream from them. The recent basalt flows lie above, most of them far above, the proposed flow lines of these reservoirs.

\section{HOLE IN THE GROUND RESERVOIR}

\section{TOPOGRAPHY}

In the lower end of a wide part of the Owyhee Canyon, known as Hole in the Ground, it is planned to build a combined storage and diversion dam. For diversion it is necessary to raise the water surface 234 feet, from an altitude of 2,356 feet to 2,590 feet above sea level. On the assumption that the maximum depth of the foundations below water will not exceed 60 feet, diversion will require a dam with a maximum height of 294 feet. If storage is also provided, the dam must raise the water level about 100 feet higher, or to 2,690 feet, and will have a total height of about 394 feet. Even if there are slight modifications in these figures, the dam will be when constructed the highest, or at least one of the highest, in the world.

The dam will stand in a narrow inner gorge known as The Box, whose side walls are preclpitous for about 350 feet and above this height flare to normal width. (See pls. 5 and 6.) 


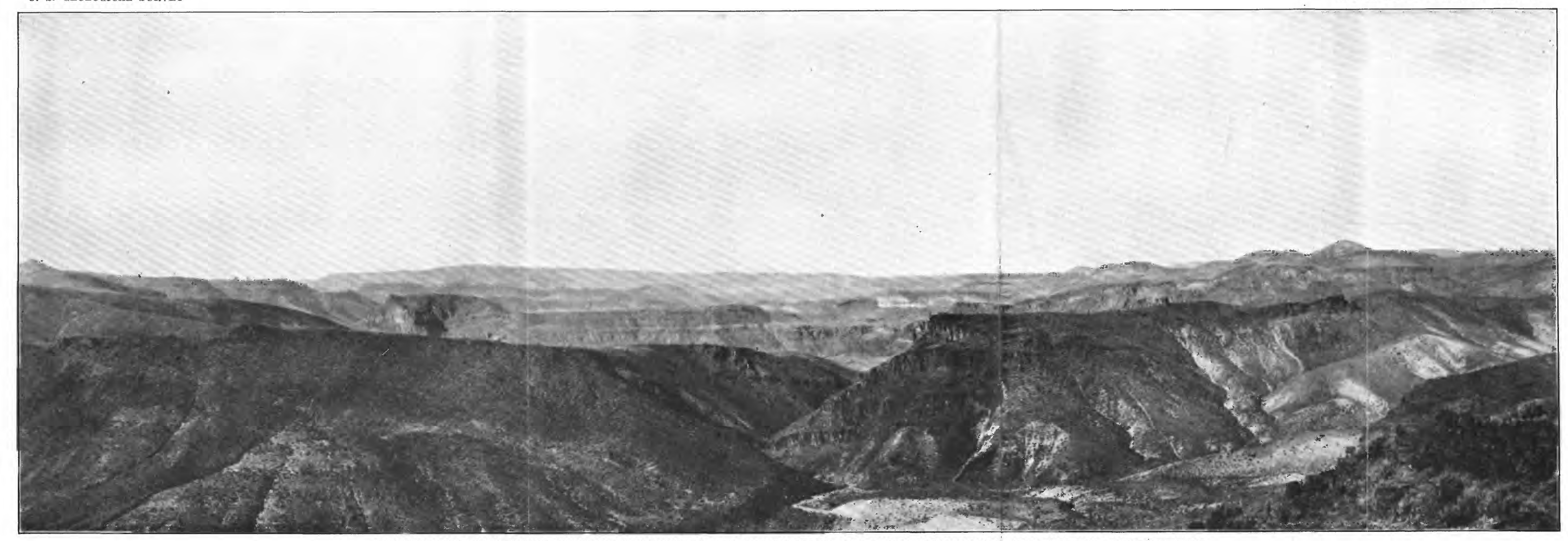

PANORAMIC VIEW OF CANYONED COUNTRY NORTH OF OWYHEE DAM SITE, OWYHEE IRRIGATION PROJECT, OREGON

Proposed canal runs through valley in the foreground. Owyhee Gorge in middle ground; Grassy Mountain and Deer Butte in barkground 


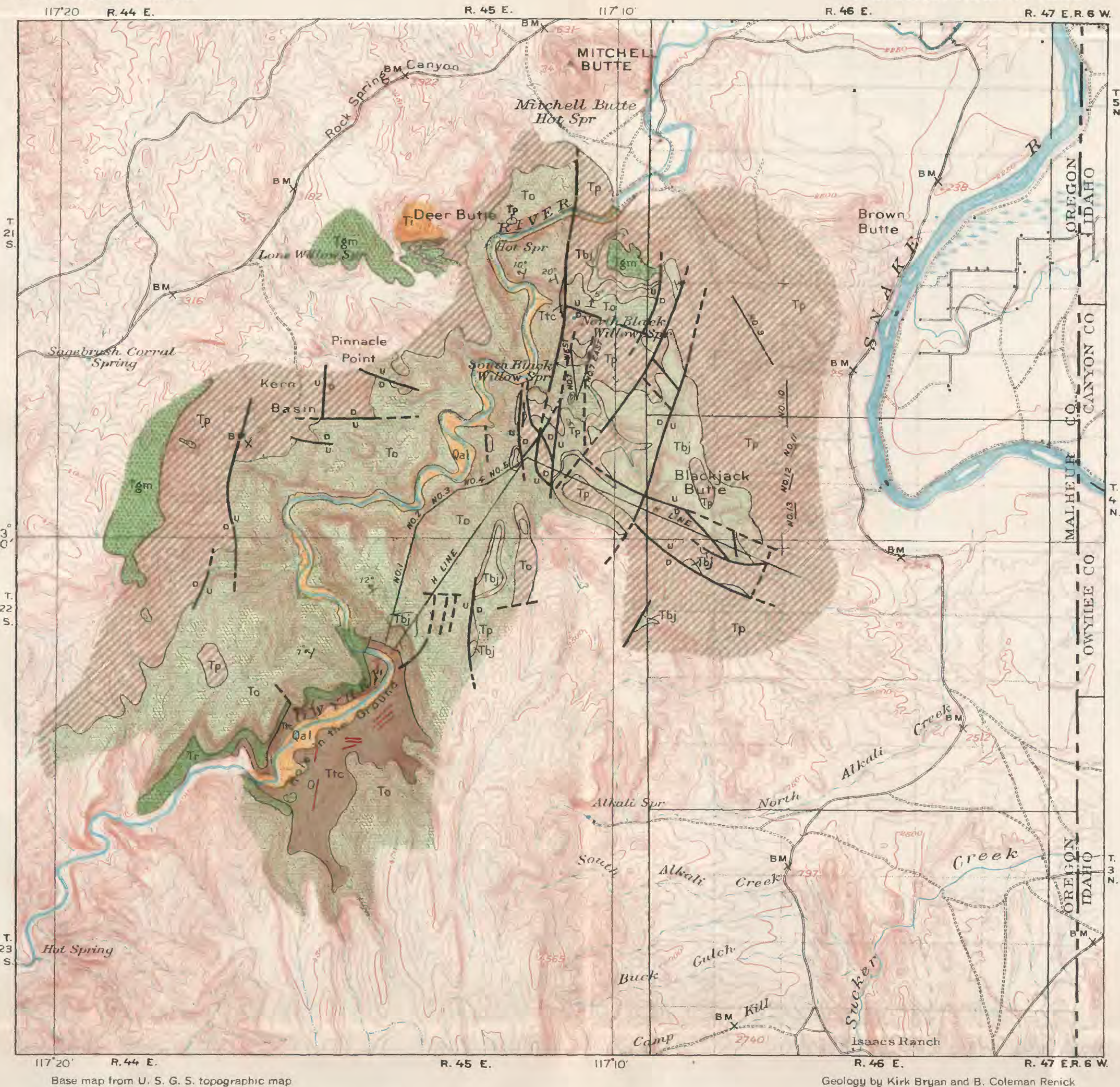

EXPLANATION

SEDIMENTARY ROCKS

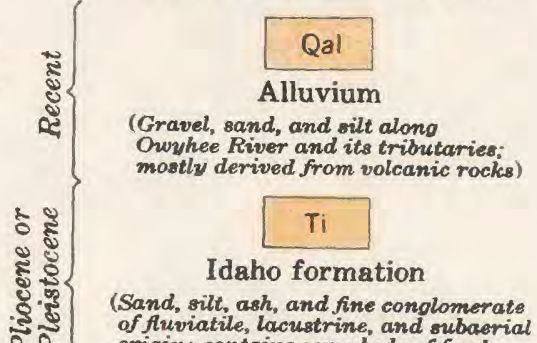

of fluviatile, lacustrine, and subaerial origin; contains some beds of fresh-

Po

Payette formation

(Sand, silt, volcanic ash, and tuff of
fuviatile, locustring and un berid

origin. Locally contains silicified

logs and bed of carbonacecus shale.

basalt east of Onph hee River and

intruded by dikes of Grassy Mountain

Tuffaceous conglomerate

(Conglomerate, sand, ash, and tuff be

underlying the Owyhee basalt and
the porphyritic rhyolite. Much

thered)

IGNEOUS ROCKS

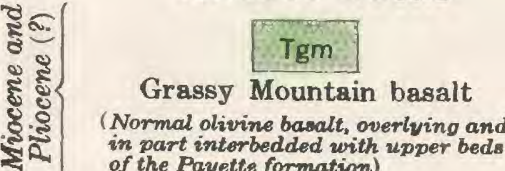

in part interbedded with upper bed.

Base map from U.S. G.S.

ITEUR COUNTY, OREG.

GEOLOGIC MAP OF PART OF THE LOWER GORGE OF OWYHEE RIVER, MALHEUR COUNTY, OREG.

$$
\text { Contour interval } 50 \text { feet. }
$$$$
\text { Tbj }
$$$$
\text { Blackjack basalt }
$$

\section{A non olivine-bearing, normal axgite-}

$$
\text { Tr }
$$

Porphyritic rhyolite

including felsite, felsite breccia, pitch

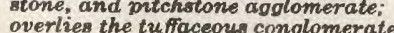

Y)

Basalt dikes

Intrude the rocks below the Owyhee basalt
and represent feedera to the basalt sheet)

$$
\text { Faults }
$$

(Known and inferred, U, upthrow;
D, downthrow)

Strike and dip 


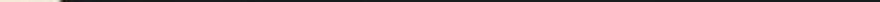




\section{GEOLOGY}

The rocks of the area are all of comparatively late geologic age and belong to the great Tertiary sequence that throughout the Northwest is marked by the accumulation of great thicknesses of lava and of almost equal thicknesses of stream and lake deposits. Only part of this series is represented in the area or is related to the proposed engineering structures. The earliest rocks are a group of stream deposits here called the tuffaceous conglomerate; sporadic lava flows, now represented by porphyritic rhyolite, covered the conglomerate in part; flows of basalt, named the Owyhee basalt, then accumulated to a thickness of 1,200 to 1,500 feet; the Payette formation, of fine white tuff and sand with conglomerate and with interbedded basalt flows, was then laid down; after which the Idaho formation, a similar but later set of beds, was deposited. In the following pages each of these formations is described in detail, and the lava flows interbedded with the Payette are given especial treatment.

The geologic map (pl. 3) covers only a few square miles adjacent to the dam, including the tunnel sites. A geologic reconnaissance of the whole reservoir site was made, but the long and arduous task of detailed mapping of this relatively large area was not considered necessary.

TERTIARY SYSTEM

\section{TUFFACEOUS CONGLOMERATE}

The oldest rocks within the area studied are of sedimentary origin and crop out in the Hole in the Ground and in a small area near the north end of the region shown on Plate 3. In both localities the beds lie beneath the Owyhee basalt, but in places in the Hole in the Ground a mass of porphyritic rhyolite intervenes between the two formations. The general relations of these formations are shown with diagrammatic clearness in Plate 7. The oldest rocks consist of alternating beds of partly consolidated conglomerate, arkosic sand, and sandy shale of a prevailing buff, light-brown, or green-brown color. Cobbles 6 inches in diameter are common, and a few boulders 1 to 2 feet in diameter were noted. From these sizes the fragments grade down to the size of sand. Most of the pebbles in the conglomeratic beds consist of brown to purple igneous rock and in places give a darker shade to these beds.

The pebbles and rock grains are all much weathered, and in consequence determination of the character of the original rocks which supplied the material is correspondingly difficult. The greater part of the material consists of basalt, andesite, and similar igneous rocks, but fragments of quartzitic arkose and single grains of quartz $100370^{\circ}-29-4$ 
and feldspar are present. The fine-grained beds are water-laid tuffs. The formation is evidently stream-laid and consists largely of débris derived from a region covered with lava flows and volcanic ash but containing also exposures of rocks of other types. In general, these materials have been only partly lithified, and the formation is not resistant to weathering. In places, however, it stands in small cliffs and produces a picturesque topography of the badland type.

As no fossils were found in these beds, their age can only be approximated. In view of the large amount of weathering to which they were subjected before the overlying rocks were deposited, it seems likely that after their deposition a period of erosion ensued. On this account it may be that the beds are as old as the Clarno formation of the John Day Basin, which ranges in age from upper Eocene to Miocene.

PORPHYRITIC RHYOLITE

GENERAL FORM AND CHARACTER

Cropping out on the west side of Hole in the Ground and forming both sides of The Box is a great sheet of igneous rock. This rock body and correlated outcrops at the south end of Hole in the Ground will be separately described under the name porphyritic rhyolite. These igneous rocks doubtless differ little in age from the associated rocks, although locally they intervene between the tuffaceous conglomerate and the basalts. The porphyritic rhyolite is massive, is marked by strong flow lines, and has the conchoidal fracture and brittleness of lavas of the rhyolite group. The main body is prevailingly red and is speckled with feldspar phenocrysts, but in places in this mass the rock is dark gray or black, and the correlated bodies farther south are wholly black. The absence of noticeable quartz phenocrysts and the glassy character of the groundmass made classification difficult.

The main body and some of the correlated masses are evidently lava flows that were extruded over the slightly eroded surface of the sedimentary rocks already described. There is at least one strictly intrusive mass, and part of the main body may also be intrusive. The detailed structure of the main body throws much light on its origin.

TYPES OF ROCK IN THE MAIN BODY

The main body of the porphyritic rhyolite consists of four unlike phases-red felsite with small quantities of similar black felsite, felsite breccia, pitchstone, and pitchstone agglomerate. In small outcrops or in hand specimens these phases appear to be rocks of 
quite different origin and might easily be suspected of different chemical composition. However, close inspection shows that there are many gradations between these types, and under the microscope they are almost indistinguishable.

The red felsite is a massive aphanitic rock of a dull red to magenta hue with colorless feldspar phenocrysts. There are also small quantities of black felsite, indistinguishable except for color. Under the microscope the phenocrysts are seen to consist of calcic andesine $\left(\mathrm{Ab}_{45} \mathrm{An}_{55}\right)$, and there is in small quantity a mineral of high birefringence that seems to be augite. Many slides show no quartz, but a few crystals were found after diligent search. The groundmass is generally glassy with a considerable amount of microcrystalline calcio feldspar. The andesine feldspar phenocrysts have a length of about 5 millimeters and the augite grains average about 0.01 millimeter.

In hand specimen or after examination of the groundmass alone most geologists would consider this rock a rhyolite. The scarcity of quartz phenocrysts and the presence of andesine feldspar and augite raised the question whether the rock might not be more calcic in its composition than rhyolite, and consequently a partial analysis was made from which a calculation of the norm, by Mr. Renick, fixed the rock in the class rhyolite, as shown in the analysis and tabulation below:

Partial analysis of a composite of several isamples of the red porphyritic rhyolite near north end of Hole in the Ground, on lower Owyhee River, Malheur County, Oreg.

[J. G. Fairchild, analyst]

\begin{tabular}{|c|c|c|c|}
\hline \multicolumn{2}{|l|}{ Analysis } & \multicolumn{2}{|l|}{ Calculated norm } \\
\hline $\mathrm{SiO}_{2}$ & 71.71 & Quartz_-_._- & 28.80 \\
\hline $\mathrm{Al}_{2} \mathrm{O}_{3}$ & 14.49 & Orthoclase & 23.91 \\
\hline $\mathrm{Fe}_{2} \mathrm{O}_{3}$ & 2. 01 & Albite & 32.49 \\
\hline $\mathrm{FeO}$ & .30 & Anorthite _._. & 10. 29 \\
\hline MgO__- & .25 & Diopside _-___ & 1.08 \\
\hline $\mathrm{CaO}$ & 2. 35 & Hypersthene__. & .10 \\
\hline $\mathrm{Na}_{2} \mathrm{O}$ & 3. 84 & Magnetite_________ & .23 \\
\hline $\mathrm{K}_{2} \mathrm{O}_{-}$ & 4.06 & Hematite _-_ & 1.92 \\
\hline $\mathrm{TiO}_{2}$ & .25 & Ilmenite & .46 \\
\hline & 99.26 & & 99.28 \\
\hline
\end{tabular}

Class I, order 4, rang 2, subrang 3.

The felsite breccia consists of angular fragments of the red felsite embedded in a matrix of similar material. The fragments range from a fraction of an inch to a foot in diameter. In a few places similar fragments of pitchstone occur. The rock was evidently 
formed by the disruption of cooled and partly cooled portions of the flow that were embedded in a still liquid portion.

- The pitchstone is a black or dark-gray rock with a vitreous luster, generally having a conchoidal fracture but in places an uneven fracture as if perlites were present. Strong flow lines, which in many places show minute crumpling and faulting, are conspicuous in weathered surfaces. Under the microscope the pitchstone is seen to contain phenocrysts similar in every respect to those of the red felsite. The glass has alternate light and dark crenulated bands. The light bands have a very minute perlitic texture. A transitional phase between the red felsite and the pitchstone repeats the characters of each. The pitchstone occurs as pseudodikes in the felsite and as blocks in pitchstone agglomerate but is similar in mineralogic character throughout.

The pitchstone agglomerate consists of a matrix of finely comminuted glass, indistinguishable under the microscope from the pitchstone already described, containing angular fragments of pitchstone bounded by conchoidal fracture surfaces and ranging from a fraction of an inch to 3 feet in diameter. 'The contrast in color between the white tuff-like matrix and the black pitchstone blocks make this a notable rock type. (See pl. $8, A$.)

\section{FORM AND GROSS STRUCTURE}

The main body of the porphyritic felsite, as shown on Plate 3, extends parallel with the general strike of the formations. South of The Box, where it crops out only on the west side of the canyon, the rock forms a wedge decreasing in thickness southward in a distance of a mile from 400 feet to a rounded end about 50 feet thick. It rests everywhere on the tuffaceous conglomerate and is overlain everywhere by white tuff at the base of the Owyhee basalt.

On-the east side of the river the mass ends abruptly on a slope having a northeast strike and a dip of $85^{\circ} \mathrm{NW}$. Here it abuts against the edges of the nearly horizontal pre-Owyhee sedimentary rocks, and the contact can be traced from a point near the river level vertically up the hillside for about 350 feet. At the top the nearly vertical mass merges into the blanket of pitchstone agglomerate described below. On the other hand, the white tuff bed at the base of the Owyhee basalt passes from the rhyolite to the sedimentary rocks over these contact phases of the rhyolite without a break.

The rhyolite forms both walls of The Box. The height of its upper surface above the river decreases from south to north gradually for half a mile, and then the upper surface slopes downward rather abruptly. The Owyhee basalt forms both banks of the river within a few hundred yards of the lower or north end of The Box. 
In gross form the rhyolite is therefore a thick lens increasing from south to north, where its form is obscured by the regional dip that carries the contacts below the surface. Some of the details of these contacts and the distribution of types of rock and minor structural - features are shown in Plate 4.

The greater part of this mass consists of the red felsite previously described. This rock is massive and resistant to erosion so that it stands in great bare cliffs, as shown in Plates 5 and 6 . It is marked by a well-defined flow structure, which throughout The Box is nearly vertical and generally has a north or northeast trend. Locally there are great sweeping curves by which the strike and dip of the flow structure change rapidly. Part of one of these curves is shown in Plate 9, $A$. In addition to the flow structure there are strong fractures, generally nearly vertical but having diverse trends. Some of these fractures are clean breaks and resemble ordinary joints. Many have sharp walls separated by 2 inches to 10 feet of fault breccia. As shown in Plate 9, $B$, these fractures resemble faults in their clean walls and contained breccia, but there is no evidence of great displacement. Also, as shown on Plate 4, they are relatively numerous near the base of the rhyolite but can not be traced through to the top of the cliffs. A few of these fractures occur at the top of the cliff but can not be traced downward any great distance. In addition to these fractures, there is a minute plating or jointing by which, on weathering, the rock breaks in slabs about half an inch thick. This minute jointing is generally nearly at right angles to the flow structure and is well shown in Plate 9.

\section{RELATIONS OF THE SEVERAL ROCK TYPES}

The several rock types of which the rhyolite is composed are mappable as units on a sufficiently large scale. In 1924 a map of the Owyhee dam site, at the south end of The Box, was made under the direction of R. J. Newell on the scale of 40 feet to the inch, with 5-foot contours. On this map, reproduced as Plate 4, the several rock types were plotted, and they were also traced beyond this small area to the limits of outcrop.

The pitchstone conglomerate forms a blanket over the red felsite throughout The Box and ranges in thickness from $10^{\prime}$ feet to as much as 100 feet. At the south end, on the east bank of the river, the agglomerate makes a sharp angle and laps around the red felsite in a nearly vertical dikelike mass along the contact with the preOwyhee sediments. This dikelike mass, as exposed, is from 20 to 50 feet wide and, as shown on Plates 4 and $6, B$, splits into dikelike bodies which join the blanket just outside the boundary of the area mapped and inclose a mass of red felsite. 
The agglomerate underlies the felsite on the west bank of the river south of The Box, laps around the end of the felsite sheet, and is continuous with the agglomerate at the top previously referred to. At the dam site the existence below the red felsite of this agglom. erate was proved in five drill holes, which permit the drawing of tentative boundaries as shown on Plate 4. At the north end of The Box the agglomerate blanket connects with several irregular dikelike masses, which have nearly vertical dips and between which are masses of red felsite. (See pl. 6, B.) Although the outcrops are more or less concealed by talus, the presence of these dikelike bodies indicates that the north end of the mass is similar in form to the border on the east side of the river mapped on Plate 4. It may be assumed that here also the red felsite with intervening pitchstone agglomerate rests against the edges of the pre-Owyhee sedimentary rocks.

From the foregoing description it is evident that the pitchstone agglomerate completely incloses the red felsite, conforming to its shape as a glove fits the hand. In places, however, dikelike masses near the more nearly vertical edges of the main mass separate relatively small blocks of the red felsite from the main mass.

The contact between the red felsite and the agglomerate is sharp and distinct, yet in detail transitional. Boundaries can be drawn within 2 or 3 feet of accuracy. The red felsite with its vertical flow lines and its minute jointing extends up to the contact, which is in places minutely irregular, having sharp crenulations of a magnitude of 2 to 3 feet as well as broader irregularities, which are brought out on Plate 4. From an examination in more minute detail along this contact, it is seen that the felsite loses its lithoidal character, pumaceous bands appear, and wedges of the matrix of the agglomerate grade into these bands. In other words, there is no real distinction between the two rocks; there is a rapid but complete transition.

In addition to the pitchstone blocks in the agglomerate there are bodies of pitchstone within the red felsite. These bodies are generally long and narrow and have nearly vertical contacts, so that they appear to be dikes. In general, they lie parallel to and between the plates of the flow structure of the red felsite. They were mapped in detail over the area shown on Plate 4. Many are isolated pseudodikes, but near the north end of the area they unite in a considerable mass, in which smaller bodies of red felsite are completely inclosed.

In general, flow structure is not apparent in these pseudodikes. They are massive and do not have the minute jointing of the felsite. Thus they appear to consist of a very different rock, especially as in a few places the pitchstone cuts across the felsite with its well- 
$x+2 x+3=$

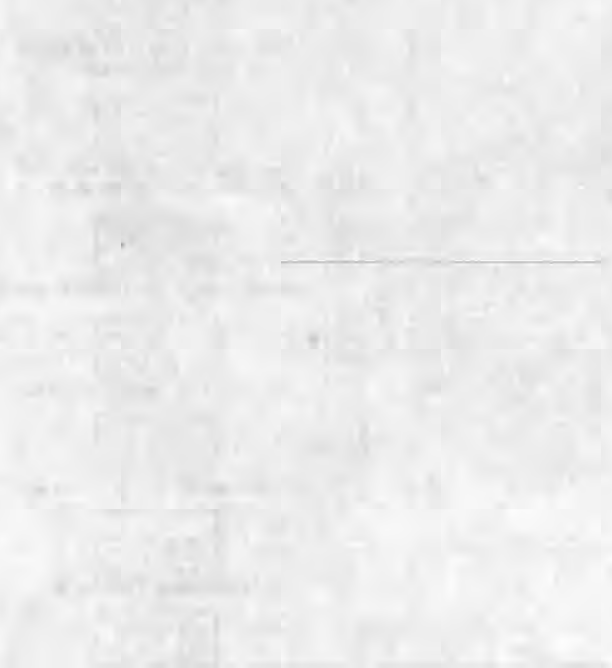




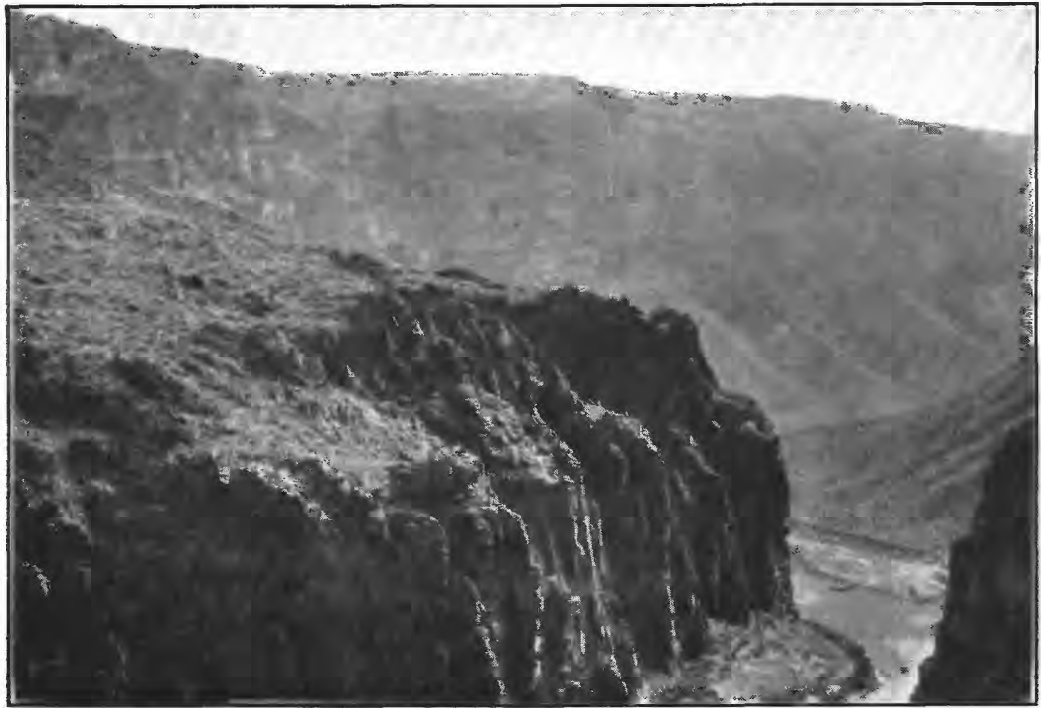

A. VIEW UPSTREAM, SHOWING THE UPPER END OF THE BOX AND PROBABLE POSITION OF THE DAM

Cliffs in foreground are red felsite; shelf above them pitchstone agglomerate; benched cliffs in background Owyhee basalt

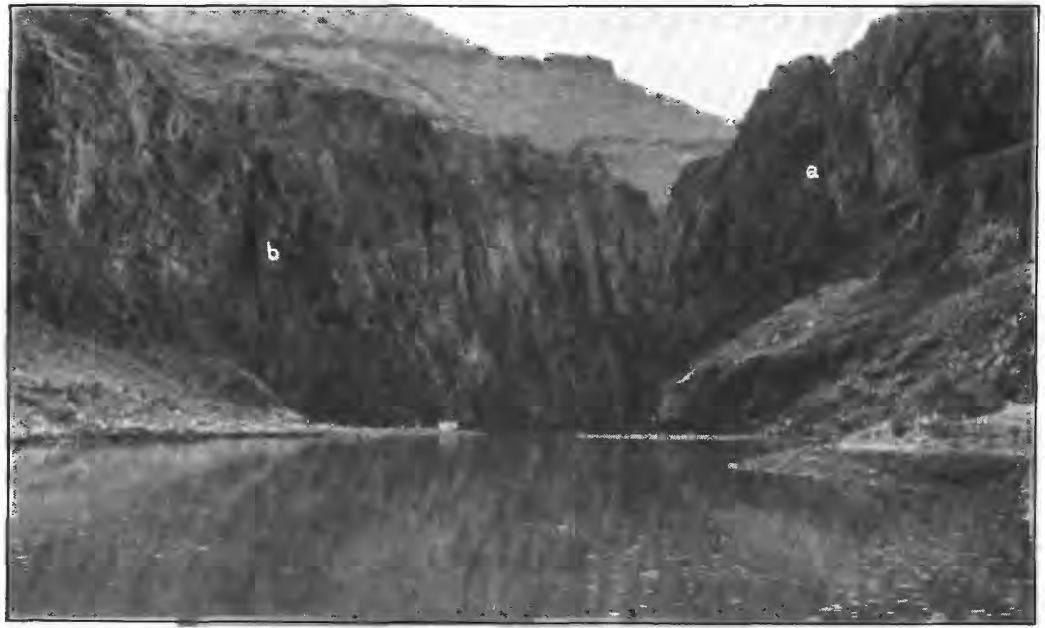

B. VIEW DOWNSTREAM TOWARD ENTRANCE OF THE BOX

Drilling rig on proposed line of dam. Note prominent vertical fracture on the narrow ridges. Points a and $\mathrm{b}$ marked $\mathrm{A}$ and $\mathrm{B}$ on Plate 4.

OWYHEE DAM SITE, OWYHEE IRRIGATION PROJECT, OREGON 


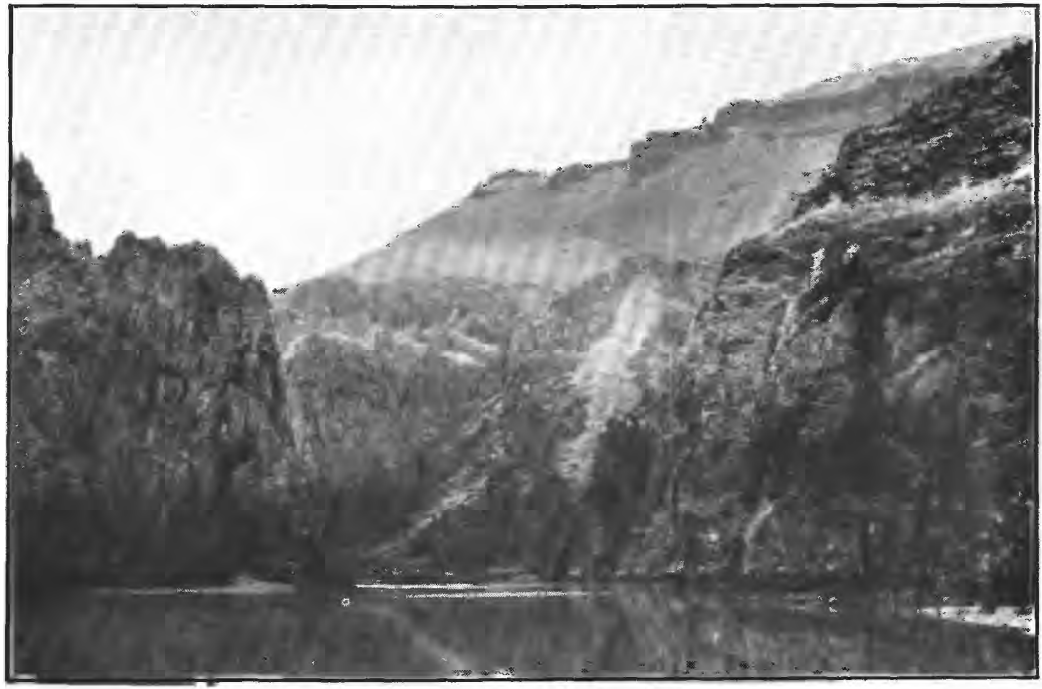

A. CENTRAL PORTION OF THE BOX

Showing the precipitous walls of felsite and the characteristic joints and fissures

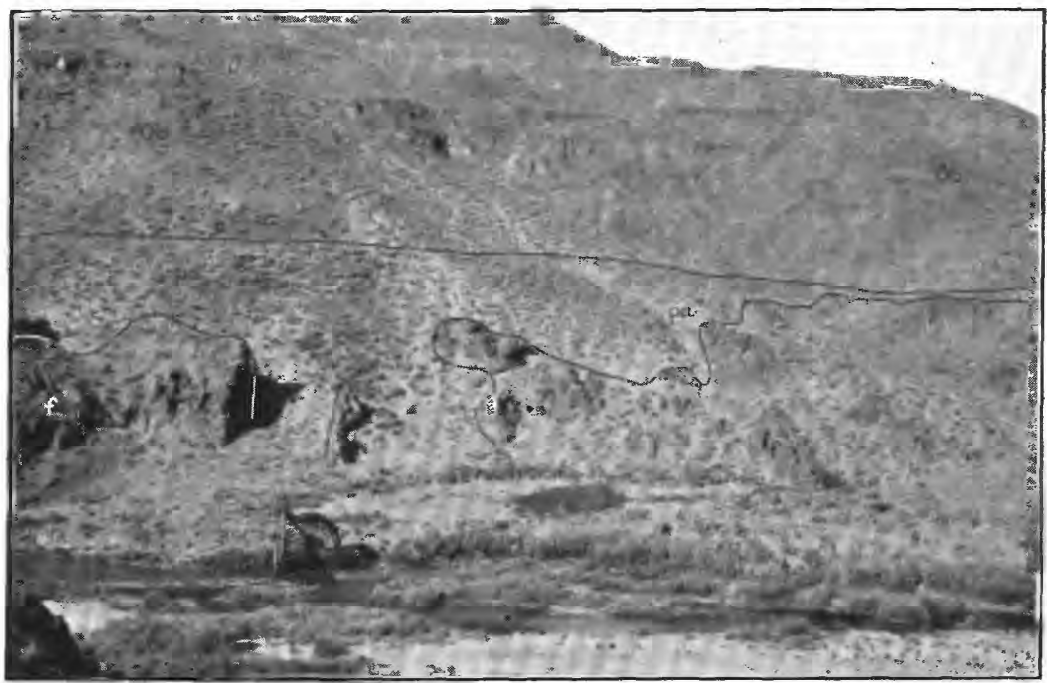

\section{B. LOWER END OF THE BOX}

Shows vertical masses of pitchstone agglomerate (pa) in the felsite (f) and the overlying Owyhee basalt $(\mathrm{Ob})$. Water wheel raises water for irrigation of small field downstream

Views of The Box, Owyhee River, Oregon 


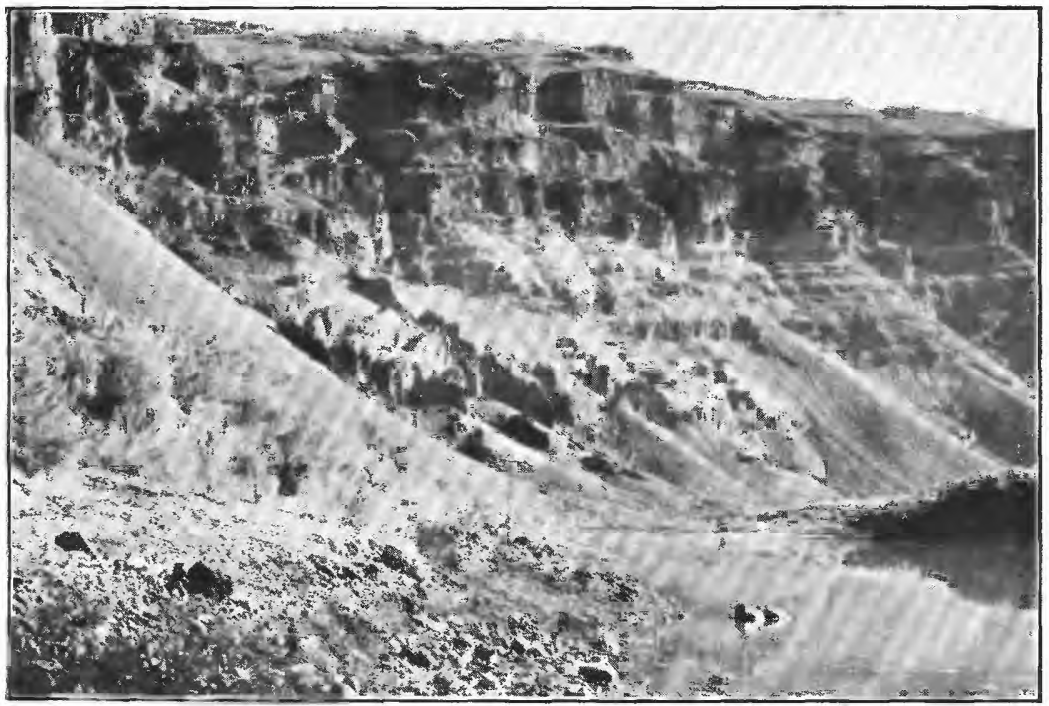

A. VIEW UPSTREAM FROM DAM SITE, SHOWING OPEN GORGE

Benched cliffs are flows and tuffs of Owyhee basalt; the slopes largely covered with talus are underlain by tuffaceous conglomerate; that in the middle ground is cut by a network of basalt dikes

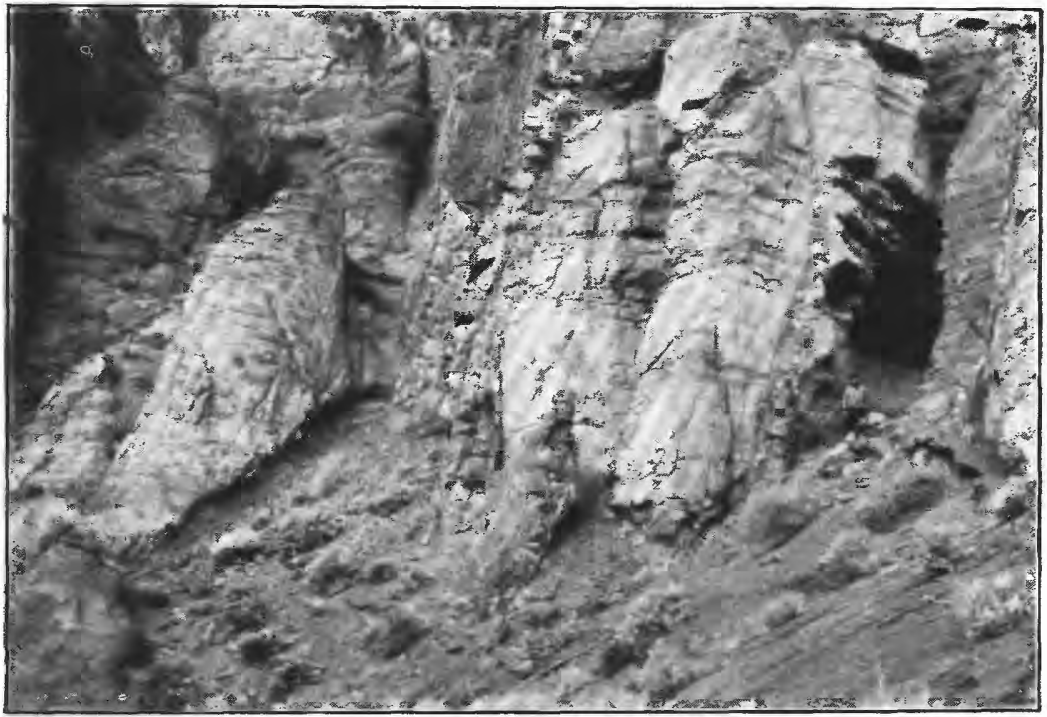

B. BASALT DIKES INTRUDED IN TUFFACEOUS CONGLOMERATE

Detail of network of dikes shown in $A$

Hole in the Ground, OWyHee River, Oregon 


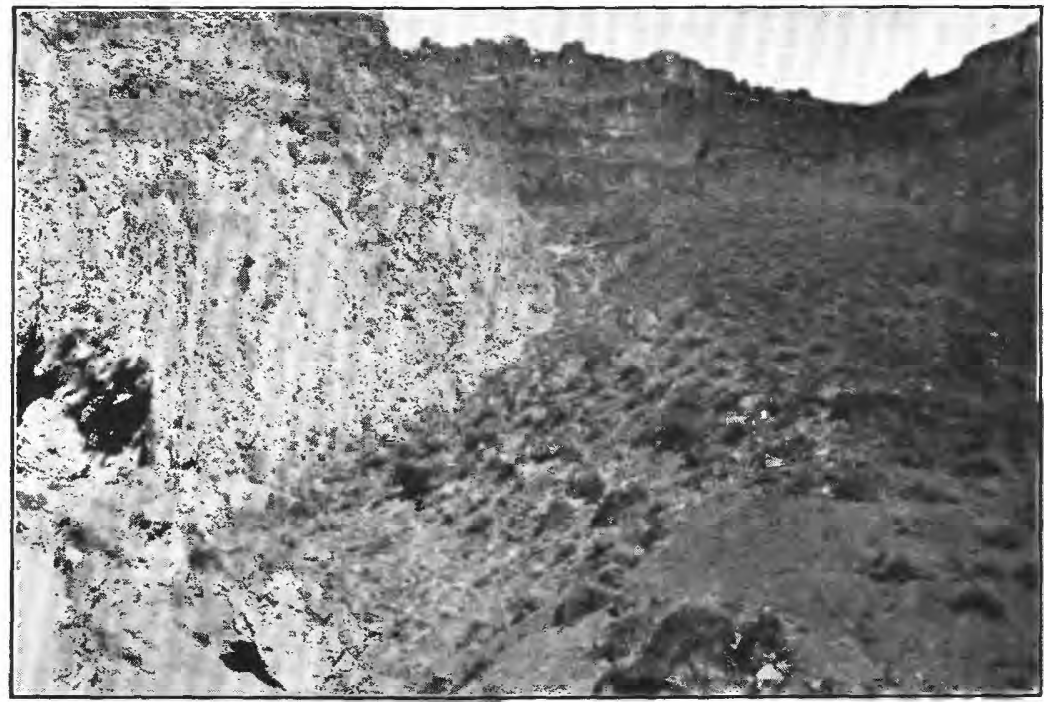

A VERTICAL MASS OF PITCHSTONE AGGLOMERATE THAT FORMS CONTACT ZONE OF PORPHYRITIC RHYOLITE ON EAST SIDE OF RIVER ABOVE THE BOX

Covered slope is occupied by tuffaceous conglomerate overlain by the Owyhee basalt, which forms the benched cliffs in the background

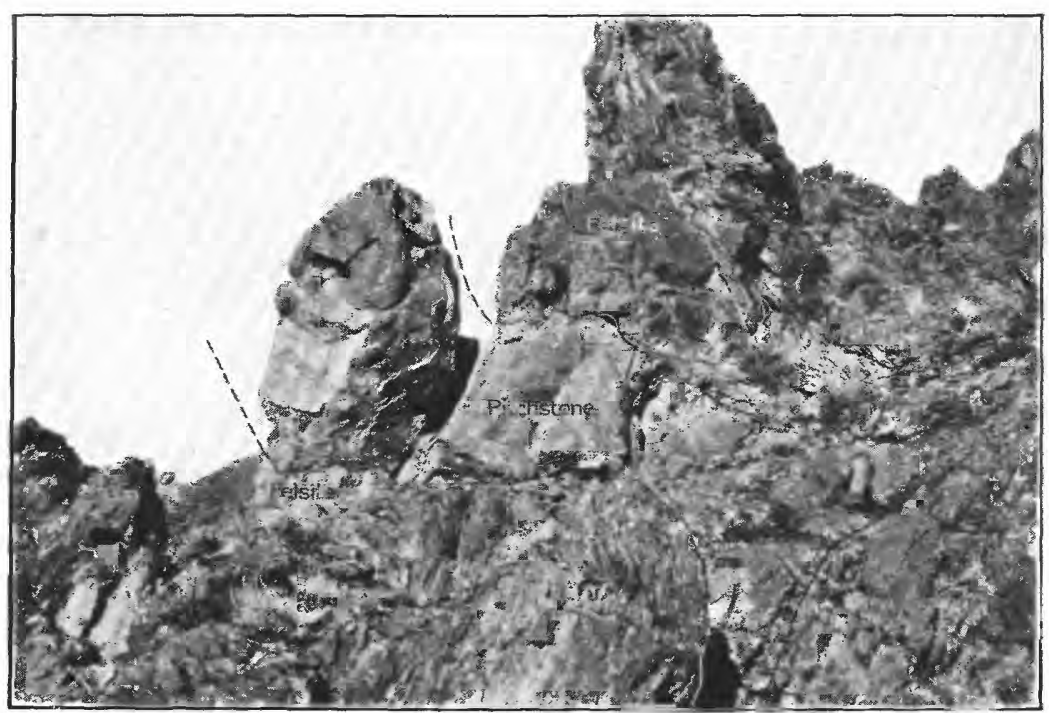

B. PITCHSTONE PSEUDODIKE IN RED FELSITE ON RIGHT ABUTMENT

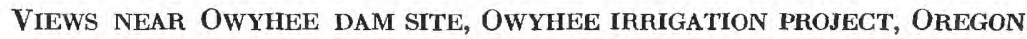


defined structure. (See pl. 8, B.) In these places the pitchstone is evidently younger than the felsite, because it visibly intrudes the felsite and breaks across the preexisting flow structure, but the general parallelism to the plates of the flow structure and the contacts, which are transitional in detail, constitute evidence that the felsite was still warm when the pitchstone dikes came into place.

The pitchstone does not crop out near river level but is confined to the top of the mass. None of the pseudodikes can be traced downward in the cliffs of The Box. These pseudodikes, therefore, were produced by a process that operated only at the top of the rhyolite mass.

South of The Box the felsite breccia crops out at the base of the mass between the pitchstone agglomerate and the red felsite. It ranges in thickness from 10 to 50 feet and grades upward into the massive and unbroken felsite and downward into the pitchstone agglomerate. In a few places the pitchstone agglomerate extends into the breccia in rounded tongues. In other places pieces of red felsite are so common in the agglomerate that there is little distinction between it and the breccia.

INTERPRETATION OF THE KNOWN FACTS

The tongue of rhyolite extending south from The Box is obviously a lava flow; the broad outcrop in which The Box is cut is of less certain origin but is either the upper part of a volcanic neck from which the flow originated or part of a flow. The interpretation to be accepted depends largely on an analysis of the conditions prevailing at the time of eruption, based on the details previously given.

As shown by the microscopic work and by the transitions at contacts, the rocks of all types form parts of a single mass. The red felsite with its oxidized iron and its lithoidal nature acquired these characters and developed its flow structure before it came to place. The generally vertical position of the flow lines, their divergences in strike and dip, and their characteristic sweeping curves indicate that the mass was stiff and almost consolidated when it came to rest. The existence of the felsite breccia at the base of the mass extending from the upper end of The Box southward is confirmatory evidence that the felsite flowed in a nearly consolidated state, for the breccia is made of fragments such as would originate from forward movement of the hardened mass by a push from the point of origin. Similarly, the fracture planes indicate that the mass was so stiff that it was ruptured by movement. The fact that these fractures can not be traced any great distance qualifies the evidence of stiffness and indicates that the rock was viscous in places, and here ruptures either did not form or else were healed as fast as they opened. 
The mantle of pitchstone agglomerate that incloses the felsite is a comminuted and more glassy phase, which doubtless was formed by the more rapid cooling of the outside of the mass. The pitchstone fragments are little different from the red felsite except that they do not contain sufficient ferric oxide to make the rock red, and jointing is absent. These fragments have doubtless never been involved in the almost solid flow that is characteristic of the felsite. They are parts of a glassy crust that consolidated sooner than contiguous parts of the felsite. The comminuted glass or tuff of the agglomerate presents a problem, as it does not appear to have been formed wholly by attrition like the felsite breccia. Perhaps there was an explosion of the surface crust of the nearly viscous flow, and almost immediately thereafter the exploded material was dragged along on the top and at the bottom of the almost solid but moving mass. The cause of the explosion may have been confined steam generated by the extrusion of the rhyolite in water, but it seems equally sound to believe that explosions of the crust in the air could produce the phenomena observed.

The pitchstone stringers or pseudodikes are in part at least of later origin than the red felsite, as they are generally parallel to and in places cut the plates of the flow structure. They seem, therefore, to have been the last liquid material in the mass, and they were doubtless squeezed from the almost solid interior through ruptures generally parallel to the flow structure. However, these pseudodikes do not extend into the agglomerate but are cut off almost at right angles by it. There is, perhaps, one exception to this statement, for near the south end of the flow, about a mile from the dam site, two stringers of pitchstone, each about 1 foot thick and 4 feet long, are wholly inclosed within the agglomerate beneath the felsite breccia and red felsite and appear to be intrusive. The presence of the blanket of agglomerate almost at right angles to the pseudodikes of pitchstone implies that locally the agglomerate was formed later than the dikes, else apophyses of pitchstone would extend into the agglomerate. Doubtless as the pitchstone was squeezed out of the interior of the flow it sent out such apophyses, but there was differential movement between the main flow and the agglomerate, which was being dragged on the top as a load. The apophyses were thus broken off in the loose agglomerate and now form an indistinguishable part of it at some distance from their point of origin.

The details of structure can thus be accounted for as sequentes of the extrusion of a highly viscous, almost solid flow of rhyolite. It remains to consider whether the broad outcrop of The Box is or is not the upper part of the conduit from which this rhyolite was extruded. 
On the east bank of the river the agglomerate abuts against the cut edges of the sedimentary tuffaceous conglomerate. The actual contact can be seen at only one point, and here the laminae of the sedimentary rock are bent down toward the rhyolite mass. The agglomerate and the sedimentary rock adhere, and chunks can be broken out that include the contact, but there is no evidence of change in the sedimentary rock by reason of heat emanating from the rhyolite. If this is an intrusive contact the rhyolite mass must have been almost cold, and what heat it contained must have been dissipated upward through the agglomerate on its border. This postulate is not incompatible with the characteristics of the rhyolite mass as already set forth.

As an alternative it is suggested that the rhyolite flowed into a valley that once existed in the area of The Box and that the former existence of the valley explains the thickening of the mass at this place. If this postulate is true, then the valley wall must have had a slope of $75^{\circ}$, for the present regional dip to the west and north must be subtracted from the $85^{\circ}$ slope of the contact, and it is questionable whether the relatively unconsolidated sediments would stand on such a slope 350 feet high. Vertical and nearly vertical cliffs 50 to 75 feet high are common, but the normal erosional slope in the Hole in the Ground is less than $45^{\circ}$. Also, if the peculiar pitchstone agglomerate that forms a sheath over the rhyolite is due to extrusion in water, then the supposed valley, at least 350 feet deep, and the adjacent upland must both have been under water, which seems to be an unlikely hypothesis.

Although the contact of the rhyolite body and the tuffaceous conglomerate seems unusual for an intrusive body, both in form and in the lack of local heat effects, yet the behavior of intrusive bodies at the point where they pass into extrusive bodies is not too well known. Certainly the details of the rhyolite adjacent to this vertical contact indicate stiff flow and moderate temperature similar in all respects to the conditions attending the southern extension of the same mass, whose character as a flow is unquestionable. It also seems reasonable that almost similar conditions should extend for 350 to 400 feet below the throat of a conduit from which such lava might rise.

\section{SIMILAR ROCK BODIES}

At the south end of Hole in the Ground, as shown on Plate 3, there are outcrops of similar rock. A thick flow that lies in the same stratigraphic position as the one already described forms a great cliff on the west side of Owyhee River. A part of the same flow forms a similar cliff on the east side and stands at higher altitudes because of the local dip of the rocks to the west. These two bodies 
have many of the features of the main rhyolite mass but are composed generally of black rather than red felsite.

Below the great flow on the east side of the river is a small mass of black felsite with obscure contacts, which may be a sill. Out on the plain to the north is a small dike of black and vitreous felsite that forms a steep though small hill. This body has nearly vertical contacts with the adjacent flat-lying tuffaceous conglomerate. It is elongated in a northwesterly direction and has a bulbous northwest end. There is an obscure columnar jointing on horizontal planes nearly at right angles to the contacts with the adjacent conglomerate. The body has therefore all the characteristics of a dike or plug that acted as a feeder to sheets of lava now eroded. The tuffaceous conglomerate at the contact is, however, little altered, although there are some bodies of platy vein material, which indicate that hydrothermal waters may have moved along the contact. The petrologic character of this intrusion is obscure and indicates that it may be a more calcic body than the rhyolite. Whether this plug fed the lava sheet a part of which crops out on the south is a question that can not be determined, but the similarity of this rock in gross habit and general appearance to the other bodies of porphyritic felsite leads to the assumption that it belongs to the same group of eruptions.

\section{OWYHEE BASALT}

Resting on the tuffaceous conglomerate in the areas where the later rock is exposed lies a great series of lava flows of prevailing basaltic type, reaching a thickness of 1,200 to 1,500 feet, to which the name Owyhee basalt is applied, from their exposures in the Owyhee River gorge. On weathered surfaces these rocks range in color from dark brown and green to red, purple, and yellow; the more brilliant colors are due to beds of cinders and included tuff. As this basalt underlies the Payette formation and is comparatively thick, it is thought to be the approximate equivalent of the Yakima basalt ${ }^{1}$ and of similar flows of Miocene age, which underlie the Columbia Plateau of Washington and Oregon. The Yakima and other basalts have generally a somber aspect, as the successive sheets of basalt and rare beds of cinders weather to shades of brown and black. The more brilliant hues of the Owyhee basalt are thus in marked contrast to them, but these colors are best displayed in the Owyhee gorge, and elsewhere the rocks have an aspect more nearly like that of the Yakima.

The major portion of the Owyhee basalt of this area consists of scoriaceous lava and cinders, but the formation includes also massive

${ }^{1}$ Smith, G. O., U..S. Geol. Survey Geol. Atlas, Ellensburg follo (No. 86), 1903. 
flows, thin flows, tuff beds, dikes, and sills. Most of the basalt flows are less than 40 feet thick, and nearly all are scoriaceous at the top and bottom. In general the basalt is fine grained and gray on fresh fracture. On microscopic examination it proves to be normal nonolivine-bearing basalt. In part of the area there is, at the top of the formation, a series of flows almost without cinders and 200 feet thick.

The cinder beds consist of the rubbly débris of basaltic eruptions and of flows of the variety called aa. Individual beds are continuous for only short distances, and changes in color are many and capricious. Some beds are markedly lenticular and are evidently buried cinder cones. The cinders consist of rock glass molded around bubbles and may best be likened to a rock froth. In general, the cinder beds are sufficiently consolidated to stand as cliffs, but they weather easily and are covered in many places by a talus of basalt blocks.

The tuff beds are numerous, but not many are continuous. They make only a small part of the whole formation, although they are conspicuous on account of their color. Some are consolidated ash showers, and others are the débris of such showers reworked in streams and ponds. At the base of the Owyhee basalt throughout the area there is a gray-white laminated tuff with grains that reach the size of a pea.

Basalt dikes from 3 to 10 feet wide, many of which pass upward into the Owyhee basalt, occur in the Hole in the Ground, and others were found at various places within the area. (See pl. 7.) All these dikes consist of basalt similar to that of the overlying flows. A few were traced upward and were observed to spread out into sills and flows. Obviously the dikes represent the vents from which the basalt was extruded and demonstrate that this formation was here built up largely by fissure eruptions.

One section of this formation was measured by Mr. Renick, but the lateral variation is so great that the beds can be traced only a small distance, and the section gives only a general idea of the character of the formation. As a summary it may be said that about twothirds of the whole formation consists of dense or vesicular basalt in the form of flows, sills, and dikes, and about one-third consists of cinders and highly scoriaceous flows, and this part includes the almost negligible tuff beds.

\section{PAYETTE FORMATION}

Overlying the Owyhee basalt in the general area there is a deposit consisting largely of fine-grained white sands and shales known as the Payette formation. These sedimentary rocks are interbedded with lava flows, to the older of which the name Blackjack basalt is 
applied and to the younger the name Grassy Mountain basalt. On the basis of fossil plants collected not many miles from the area here considered, the age of the Payette formation has been determined as Miocene. ${ }^{2}$ Above the Payette in this general region are similar beds, known as the Idaho formation, which, on the basis of collections of fossil bones and fresh-water shells, are thought to be of Pliocene or Pleistocene age. It is difficult to distinguish between these formations, and the deposits mapped and described in this report as Payette formation may in places include beds belonging to the Idaho formation.

The two sets of lava flows that in this area are interbedded with the white sands and clays of the Payette formation have large importance in relation to driving tunnels.

The beds of the Payette formation are largely white or light gray and generally fine grained, but pebble beds and conglomerate also occur. The white sands and shales appear to be largely the deposits of river flood plains or of the shallow lakes characteristic of alluvial plains. A few beds are partly consolidated ash of volcanic showers that buried the country and were little worked by streams.

In general the beds are soft, easily eroded, and only sufficiently consolidated to stand as cliffs 30 to 50 feet high. However, the conglomerate and pebble beds are hard and massive and where they occur form conspicuous cliffs and buttes, as in Deer Butte and Mitchell Butte.

The thickness of the Payette beds is not uniform in the area, and the formation thins on approach to the canyon of Owyhee River. Apparently, before or perhaps during the deposition of the Payette, the region was deformed and a ridge was produced in about the position of the present course of Owyhee River. On the west side of the river a section measured by Mr. Renick on the east flank of Grassy Mountain showed 806 feet of sand, sandstone, shale, and tuff to the base of the lava flows that cap the mountain. On the east side of the river the corresponding interval is about 400 feet. Similarly, on the rim of the canyon above Hole in the Ground the westward extensions of the lavas that cap Blackjack Butte rest on the Owyhee basalt with less than 50 feet of shale and sand intervening, and at one point no shale could be found. Four miles to the east, at Blackjack Butte, this interval is about 300 feet. As no lavas of the Blackjack type have been found west of the canyon, the ridge appears to have been an effective barrier to the westward spread of these flows.

\footnotetext{
a Knowlton, F. H., Flora of the Latah formation at Spokane, Wash., and Coeur d'Alene, Idaho: U. S. Geol. Survey Prof. Paper 140, pp. 17-81, 1925.
} 
In the single locality where lava flows from Grassy Mountain have crossed the river nearly 300 feet of sand, shale, and tuff intervene between the base of the Grassy Mountain basalt and the top of the Blackjack basalt.

\section{BLACKJACK BASAIT}

Blackjack Butte is capped by flows of basalt, named Blackjack basalt, which have a thickness of 350 to 450 feet. These flows decrease in thickness westward and finally are represented on the rim of the canyon of Owyhee River only by a single flow about 50 feet thick. This basalt is interbedded in the middle part of the Payette formation.

The Blackjack basalt is black, brown, and red in the outcrop and generally dark gray on fresh fracture. The rock usually has a banded texture in both vesicular and nonvesicular types. The bands, which are rudely parallel with the top of each flow, are marked by lines of flattened vesicles or narrow wavy openings along which doubtless the volcanic gases were accumulated and expelled. Most of the vesicles are empty, but some are lined with a thin deposit of white amorphous carbonate or a green mineral (chlorite?). In places the sheets of lava are mostly a rubble of vesicular fragments, and here and there the flows are red. Two small cinder cones are attributed to these flows, but most of their material is thought to have risen through fissures. On microscopic examination the Blackjack basalt proved to be very similar to the basalt of the Owyhee flows and without notable peculiarities.

\section{GRASSY MOUNTAIN BASAIT}

The lava flows of Grassy Mountain, named Grassy Mountain basalt, have a thickness of at least 200 feet. In the base of Deer Butte the total thickness is $\mathbf{1 7 2}$ feet, in three separate flows, and in the only outcrop east of the river the thickness is about 50 feet.

This lava is generally black to greenish black on outcrop, although there are large areas where it is red or purplish. The vesicles are generally filled with white carbonate, but in one outcrop the filling is green. The rock is notable in this area in that it contains olivine phenocrysts and can be distinguished easily from other flows in hand specimens. The Grassy Mountain basalt in part overlies the Payette formation and is in part interbedded in the upper part of the Payette.

\section{IDAHO FORMATION}

The Idaho formation, which on the basis of collections of fossil bones and fresh-water shells is thought to be of Pliocene or Pleistocene age, is usually difficult to separate from the underlying Payette 
formation, of Miocene age, the two formations consisting of similar materials. Some indistinct shells collected by Mr. Renick at Deer Butte give evidence that the Idaho formation is probably present, and the area supposed to be underlain by it has been differentiated on Plate 3. It.is possible that the formation is present at other places within the area and that it has been included in the deposits here mapped and described as Payette formation.

\section{QUATERNARY SYSTEM}

The alluvium on the banks of Owyhee River and the gravel bars that are found on a few terraces within the canyon are of Quaternary age, but these deposits have not been studied. The larger areas are grouped together on the geologic map.

\section{GEOLOGIO STRUCTURE}

The Owyhee basalt and the sedimentary rocks that underlie this great series of flows were once nearly horizontal. The first earth movement recorded in this area is the slight deformation that arched a ridge prior to the deposition of the Payette and Idaho formations. It seems likely that the production of this ridge was only a minor feature of a much larger disturbance by which the Snake River region on the north was carried below the volcanic plateaus on the south. Certainly at Ontario, 30 miles north of this area, the thickness of the Payette and Idaho formations is more than 4,000 feet, as shown by the $\log$ of a deep well, ${ }^{3}$ and only 8 miles north a well 1,140 feet deep has been drilled without striking the basalt. In the region here considered the deformation was moderate, permitting the accumulation of only some hundreds of feet of sand, conglomerate, clay, and volcanic ash, together with the interbedded lava sheets of the Blackjack and Grassy Mountain flows.

A period of intense dislocation followed, during which the area was broken by faults. These breaks are many and complicated. The principal fault zone trends north and lies just east of the Owyhee gorge. The total displacement is about 1,500 feet, and all the formations west of this fault are tilted to the west. The summation of displacement on faults of smaller throw, both east and west of this main fracture, is such that the higher rocks are carried to lower altitudes both east and west. Thus in approximately the position of the original ridge has been developed a pseudoanticline in which the older rocks are brought near the surface and bordered on each side by younger rocks. This structure also is only one of the minor re-

${ }^{3}$ Washburne, C. W., Gas and oil prospects near Vale, Oreg., and Payette, Idaho: U. S. Geol. Survey Bull. 431, pp. 41-42, 1911. 
sults of the greater movement by which the Snake River Basin was . carried below the plateaus of southeastern Oregon and southern Idaho.

\section{THE RESERVOIR}

The reservoir created by the building of the dam at Hole in the Ground will extend up the canyon about 40 miles, to the vicinity of Watson post office. This long, narrow body of water will have its greatest width in those parts of the canyon where the rocks are soft and the slopes gentle. The only large extension will be in the valley of Dry Creek, which enters Owyhee River some 10 miles above the dam site.

In a hurried reconnaissance made through this reservoir site in 1923 the rock formations were examined with regard to leakage. In the Hole in the Ground the reservoir water will rest wholly against the tuffaceous conglomerate of pre-Owyhee age. The conglomerate is relatively open and porous, though it is so much weathered that on being wet the clayey minerals should expand and close many pore spaces. The beds are cut by many nearly vertical basalt dikes. Although a continuous dike or chain of dikes does not exist, it may be safely assumed that these dikes will force the water to take very intricate courses in moving through the formation. These intricate courses and the frictional resistance to flow through the pores of the rocks will, irrespective of other rocks that may also resist water movement, effectively prevent percolation between the reservoir and Snake River Valley, which lies 7 to 12 miles to the east. At the south end of the Hole in the Ground the water will rest against bodies of rhyolite. This rock is tight in itself and, as previously pointed out, rests on the tuffaceous conglomerate, which will obstruct any leakage that might pass the rhyolite.

Owing to the complicated faulting of the region, the Owyhee basalt forms the floor of the reservoir for 2 miles and the eastern wall for 4 or 5 miles farther south. This formation consists largely of lava flow and is undoubtedly extremely pervious to water. Throughout this area it dips $5^{\circ}-10^{\circ} \mathrm{W}$. As the tuffaceous conglomerate underlies the basalt, this formation must be present to the east, and will here, as farther north, form an effective barrier to movement of water from the reservoir eastward.

Upstream from the last outcrop of the Owyhee basalt, clay, shale, and tuff, with here and there rhyolite dikes and flows, form both sides of the reservoir for a distance of 25 miles. Some of these beds may belong to the Payette formation, but most of them appear to resemble the Mascall, John Day, and Clarno formations of other parts of Oregon. In general, the beds are horizontal or have only low dips. Most of the beds are fine grained and will transmit water only slowly, 
and the presence of the rhyolite dikes will also interfere with the movement of water. It should be noted also that tributary streams in this part of the Owyhee Canyon have small flows in the dry seasons. These flows are doubtless fed by ground water and indicate that the slope of the water table is toward Owyhee River from both sides. A reservoir built in such a depression of the water table can not leak, for movement out of the reservoir is resisted by the inflow of ground water toward the reservoir.

\section{THE DAM SITE}

The proposed dam is to be built where the main body of the porphyritic felsite crosses Owyhee River at The Box, the narrow gorge that lies at the north end of the Hole in the Ground. As this dam is to be very high, much consideration must be given to all the facts that relate to its foundation.

The red felsite of The Box has a relatively high crushing strength and is free from pores or large cavities except near its borders or along the fracture system. It is therefore a suitable rock for the foundation of a high masonry dam of either the gravity or the arch type. Its principal disadvantages arise from the fractures and from the peculiar shape of the rock mass with respect to the topography of the gorge.

The fractures are of two types-the minute horizontal sheeting and the nearly vertical fracture system. The horizontal fractures are intensified by weathering, and on exposed surfaces the rock is divided into wavy plates from half an inch to 2 inches thick, as is well shown in Plate $9, B$, in the lower left corner. These fractures do not appear in the drill cores of test holes and are not open in depth, though they doubtless exist in an incipient form. Although they doubtless slightly lower the strength of the rock, they can have little effect on the proposed structure.

The vertical fracture system consists of fractures that follow nearly vertical planes having several trends. The most extensive of these fractures in the upper part of The Box are shown on Plate 4. The fractures have clean, continuous walls, which in many places are slickensided. Where the walls are separated there are in places open cavities, but in general the space between them, which may be from 2 inches to 10 feet wide, is filled with fragments of rock. In most places the fragments are more or less cemented and form a breccia, but this breccia is obviously inferior to the original rock in strength and resistance to weathering. The breccia also forms channels for the movement of water through the abutments of the dam. The nature of the fractures and the breccia is shown in Plate 9, $B$. In Plate 9, $A$, the dark vertical band is one of these fractures that cuts across the flow structure. 


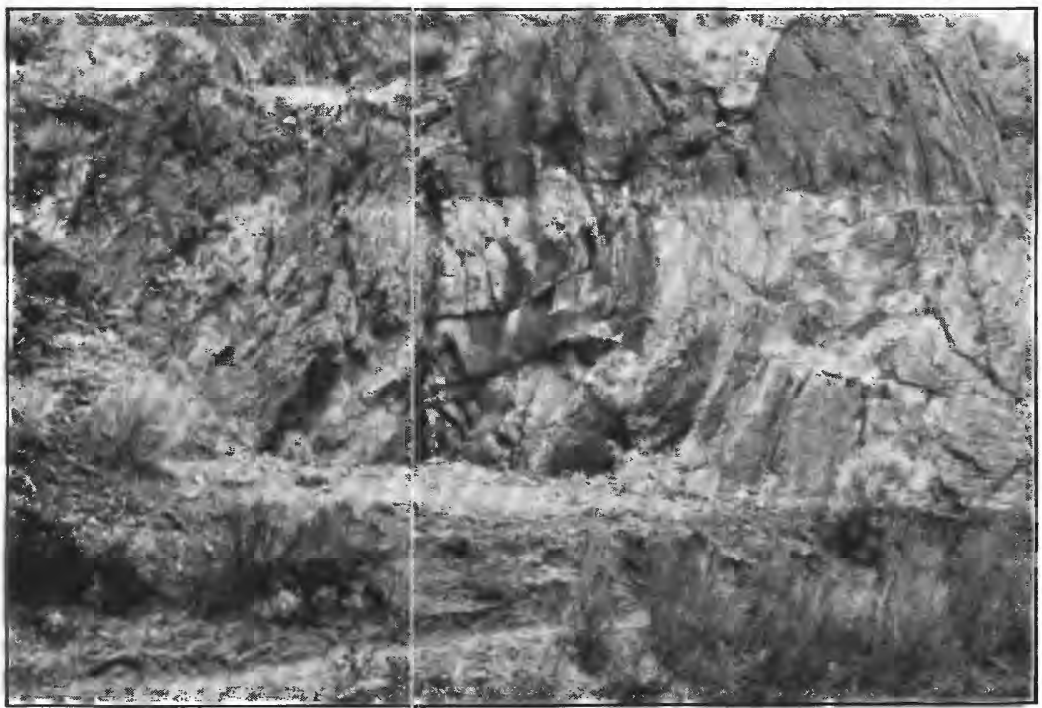

A. CURVED AND NEARLY VE'RTICAL FLOW STRUCTURE IN RED FELSITE

Note numerous closely spaced horizontal joints, also vertical fracture, which shows as a narrow dark band. The horizontal line al, the top of the light-colored zone is a high-water mark

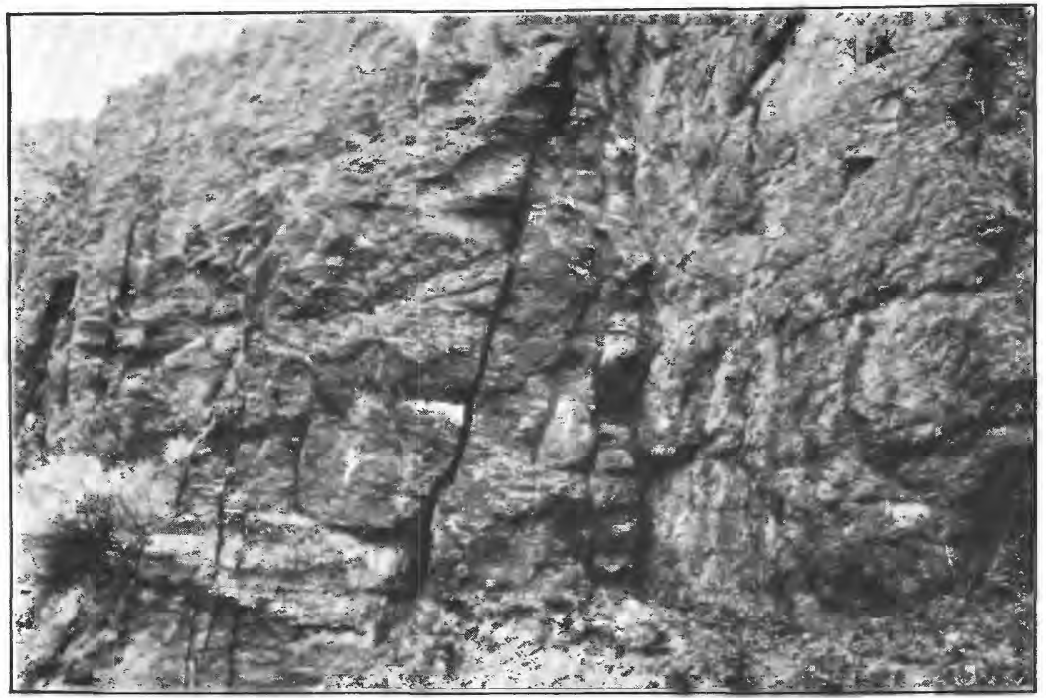

B. VERTICAL FRACTURES IN RED FELSITE

Some are clean breaks; others have a mass of comminuted rock fragments between the walls. Closely spaced horizontal fractures show at the left 



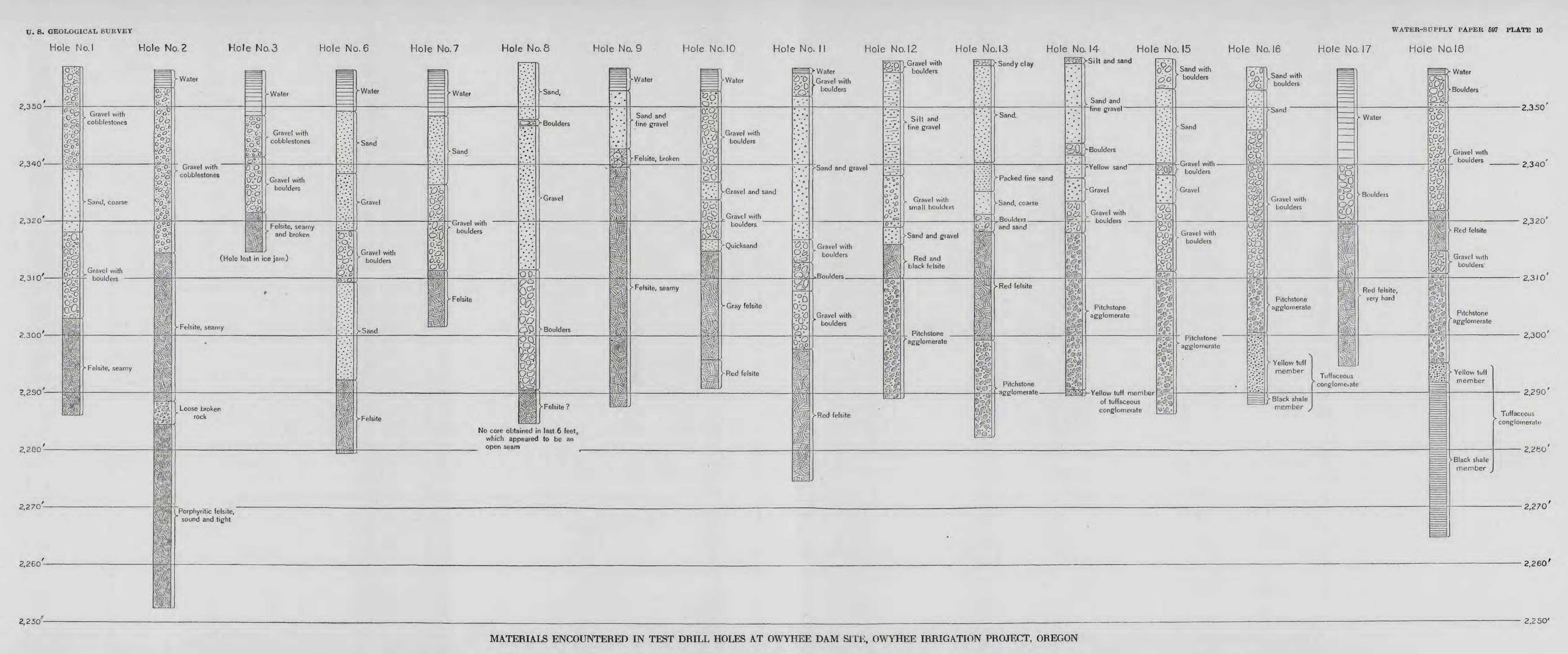


These fractures exist only in the lower parts of the canyon wall and can not be traced through to the top. Therefore they do not weaken the abutment as a whole, nor should leakage on a large scale be feared because of their presence. The fractures are of most consequence in the narrow prongs of rock marked " $\mathrm{A}$ " and " $\mathrm{B}$ " on Plate 4, where weathering has opened them. (See also pl. 5, B.) It seems likely that if the dam is so located that either of these prongs or points serves as a part of the abutment large quantities of rock must be removed in order to clean out these fractures completely and fill them with concrete. It is likely also that pressure grouting should be used in order to seal cracks not readily visible.

The southern boundary of the red felsite mass has a complicated form which has a direct bearing on the details of location of the dam. On the right (east) side of the river the boundary is nearly vertical, on the left (west) side it dips $10^{\circ}-20^{\circ} \mathrm{SW}$., and in the bed of the river the boundary is a warped surface of adjustment between these two divergent planes. The characteristics of this bounding surface where it is concealed by the alluvium of the river were brought out by the test drilling of 1923 . The logs of the holes within the area of Plate 4 are shown graphically in Plate 10. Test holes 12, 13, and 15 passed through the red felsite into the pitchstone agglomerate and holes 16 and 18 were continued through the agglomerate and thence into the tuffaceous conglomerate. By the use of this information the trace of the pitchstone agglomerate has been represented on Plate 4 with fair accuracy.

The strength of the pitchstone agglomerate and of the tuffaceous conglomerate is moderate, and these rocks can not be deemed strong enough to support a high masonry dam. The dam should therefore be located far enough within the throat of the gorge to rest wholly on the red felsite, or else additional concrete should be provided so as to lessen the load to the square foot in the part of the base where these soft rocks occur.

As the red felsite tapers toward the south to a feather edge, a decision must be reached as to the thickness necessary to afford adequate support for the dam. The record of drilling shows that the red felsite is not uniform in strength and in places is seamed and fissured. These fissured portions can be much strengthened by pressure grouting, and if thorough grouting is done over the whole base of the dam, a less thickness of felsite can be tolerated than if this device is not used. As the fractures of the felsite are clean-walled breaks, conditions for effective grouting are excellent. An arbitrary decision must be made as to the thickness of felsite that will be tolerated, and I suggest that a thickness of 20 feet thoroughly grouted could be considered equivalent to a thickness of 50 feet ungrouted. $100370^{\circ}-29-5$ 
If a location well within the throat of the gorge is chosen, there will be ample thickness of felsite, as shown by drill hole No. 2, and these considerations are of no importance.

\section{POSSIBLE IEAKAGE THROUGH ABUTMENTS}

In so far as the red felsite forms the abutments no serious leakage need be feared, for the cracks of the rock can transmit only small quantities of water, and as the rock is not soluble this leakage will not increase. As the cracks are clean and free from clay or other disintegration products, they may, if necessary, be readily sealed by pressure grouting.

The left (west) abutment consists wholly of this rock, but in the right (east) abutment the felsite is bounded by a nearly vertical surface against pitchstone agglomerate. The agglomerate, which is in places 50 feet wide, is a porous rock and might transmit water. However, the only place where this water might emerge is at the north end of The Box, about half a mile distant. What path it would travel is problematic, but probably the path would be complicated and indirect. Even if the path were direct, the loss of water through the agglomerate with a hydraulic head of 500 feet to the mile would be moderate, for the material is fine grained. It is so tightly cemented and so compact also that the formation of channels is not to be feared. Similarly, water might travel through the tuffaceous conglomerate and thence into the Owyhee basalt. However, the tuffaceous conglomerate is locally very compact and is cut by a basalt dike very close to its contact with the pitchstone agglomerate. (See pl. 4.) This dike will form an effective barrier to the leakage of water through the conglomerate.

\section{SPILIWAY}

If a spillway is planned across one of the abutments, as on the right (east) of the dam site, where, as shown in Plate 4, there is adequate room, then the resistance of the felsite to erosion becomes important. Owing to the intimately jointed and fissured condition of the rock, large quantities of water at high velocity will erode the rock rapidly. This action should be avoided by concreting the spillway or by some other adequate device.

\section{TUNNELS}

Under the plans proposed the water is to be distributed by a conduit that will leave the reservoir east of the dam. As the conduit will pass through rough country it will consist in part of tunnels. All these tunnels are shown on Plate 3, except Nos. 6 and 8, which are very short, and No. 14, which is 4,800 feet long and runs west of Mitchell Butte. 
The rocks to be encountered have been grouped under four classes, as follows:

1. Tuffaceous conglomerate-a series of stream deposits of greenishyellow rock traversed by basalt dikes. The formation is compact but not hard and will be easy to drill but will require a slow-acting powder. It will stand well without timber. It is cheap rock to tunnel except for the dikes, which will form obstructions to rapid progress.

2. Owyhee basalt-a series of lava flows with intercalated tuff and stream deposits and about 1,500 feet thick. Some flows are dense, hard rock; others are porous, partly cemented rubble. In general this formation will stand well in tunnels and will require timbering only in weak places; however, the porous layers will require much powder, and a change in methods will be required as the tunnel passes from one member to the next. It is believed that this rock will generally be more expensive to tunnel where inclined than where horizontal or nearly so.

3. The rocks herein designated the Payette formation, but including the Idaho formation, if that is present, consist of a series of finegrained sediments containing much volcanic ash. The beds are usually white and range from sand to clay. There are hard conglomerates in the formation, but none occur in the tunnel sites. Tunnels in the Payette will be easily dug and will require timber only near the portals and occasional temporary support unless the ground is wet or the material much weathered. Plans should provide, however, for following quickly with the concrete lining, because at least part of the material will slack and weather rapidly.

4. Blackjack basalt-lava flows, which spread out over the area during the time of the deposition of a part of the Payette sediments. This formation ranges in thickness from 50 to 400 feet and lies from 50 to 350 feet above the base of the Payette. The rock is a hard black vesicular basalt. It will be hard to drill and shoot, but the difficulties of working in it will be no greater than those encountered in tunnels in basalt on the Yakima project.

On the basis of existing knowledge of the geology of the region prediction as to the rocks that may be encountered in tunnels is somewhat precarious. However, it is believed that the predictions given herewith are sufficiently accurate for estimating cost. Further information obtained from drill holes may be necessary for construction.

On the line of conduit first proposed, which is called the G line, there are 14 tunnels, numbered from 1 to 14 , beginning at the reservoir. The $\mathrm{H}$ line would include three tunnels of the $\mathrm{G}$ line and two others. 


\section{Rocks in tunnels on the $G$ line}

Tunnel 1:

Tuffaceous conglomerate

Owyhee basalt, nearly horizontal

Tunnel 2: Owyhee basalt, nearly horizontal

Tunnel 3: Owyhee basalt, nearly horizontal.

Tunnel 4: Owyhee basalt, nearly horizontal

Tunnel 5:

Owyhee basalt, nearly horizontal

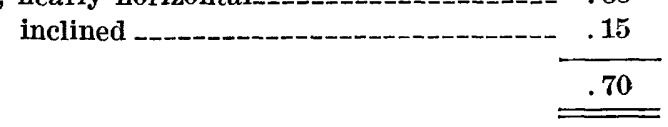

Tunnel 6:

Blackjack basalt, consolidated cinders______________._. .075

hard block lava_-_. . 075

Tunnel 7, west line:

Owyhee basalt, inclined, but mostly consolidated cinders_..._-_._._. 4

Payette formation_._._-_._- . 2

Tunnel 7, east line:

.6

Owyhee basalt, inclined, but mostly consolidated cin-

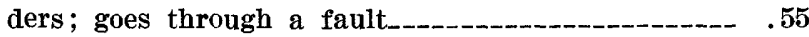

Payette formation_______. 1

Tunnel 8 (in low pass) : Payette formation, probably somewhat weathered and may require timbering throughout_- $\mathbf{. 2 5}$

Tunnels 9, 10, 11, 12, and 13: Payette formation.

Tunnel 14 (Mitchell Butte) : Payette formation, doubtless weathered and may require timbering.

\section{Rocks in tunnels on the $H$ line}

Tunnel 1:

Tuffaceous conglomerate

Owyhee basalt, horizontal

inclined

2

Tunnel 2:

Owyhee basalt, horizontal _._____ 2.36

inclined___._._._. 79

Payette formation

Blackjack basalt, inclined__._._._._._._._._._._._._. 

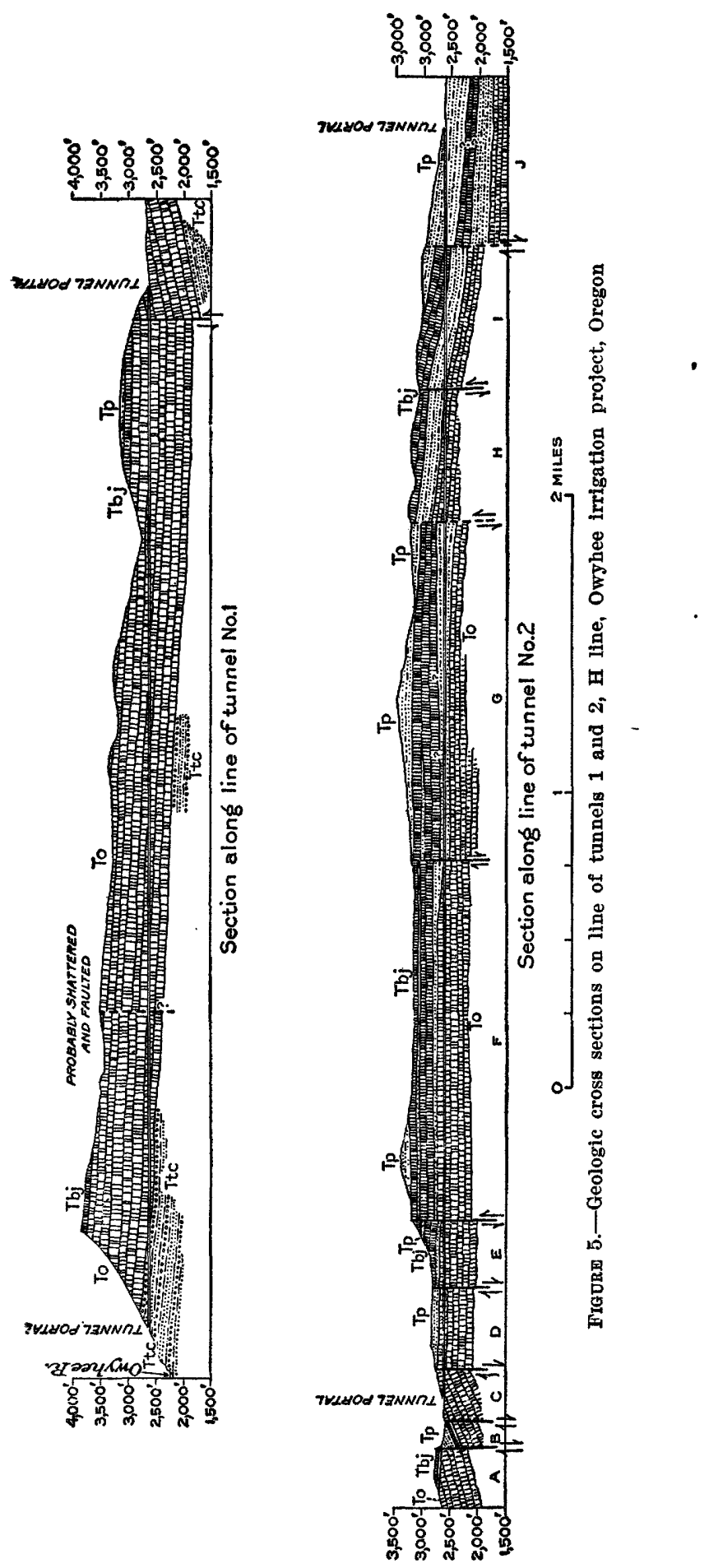
Tunnel 2 has the most complicated structure of all listed, and the uncertainties are the greatest. Tunnels 7,8 , and 14 of the $G$ line are used also in this line.

The first ridge penetrated by the first tunnel on both the proposed lines has relatively simple geology, which is shown in the cross section drawn on the line of tunnel 1, H line, given in Figure 5. The gravest uncertainty is the relative amount of tuffaceous conglomerate and of Owyhee basalt that will be encountered. Obviously, if the dip of the rocks is greater than is shown in the section the distance of tuffaceous conglomerate to be traversed is shorter; if the dip is less, conditions are reversed. Although the cost of tunneling in the tuffaceous conglomerate will be less than in the basalt, the cost of drill holes to test the validity of the cross sections as plotted would be so great, on account of the heavy cover, that such tests are doubtless inadvisable.

Tunnel 2 of the $\mathrm{H}$ line presents the most complicated geology. The faults are numerous, and the Blackjack basalt increases in thickness. from 50 to about 400 feet along the line of the tunnel. The cross section shown in Figure 5 must therefore be considered no more than tentative. The faults are here shown as vertical, but it is certain that most of them are inclined and will be encountered in the tunnel at one side or other of the positions shown. It is impossible, however, without test drilling to improve much on the predictions given in this cross section. As the value of exact knowledge increases with the spread in cost between different classes of material, it becomes an engineering problem to determine whether this tunnel line should be drilled in order to provide more exact data. With such exact data, it might be possible to make part of this tunnel a pressure siphon and hold it for most of its course in the soft Payette formation. Such possibilities present themselves from a consideration of the cross section, but more exact knowledge is necessary before plans can be formulated.

The predictions on the smaller tunnels are considered reasonably accurate, and drilling to verify them is probably not required. Most of these tunnels have a shallow cover, and test holes need not be deep and consequently will not be expensive.

\section{TEMPERATURE IN TUNNELS}

The temperature likely to be encountered in a tunnel is always difficult to predict, and no available data are directly applicable to the problem. However, areas that are underlain by volcanic rocks, as this one is, are likely to have high ground temperatures. The presence of hot springs in the area also indicates a high thermal gradient. Data on the known springs are shown below: 
Temperature of springs in Owyhee irrigation project, Oregon

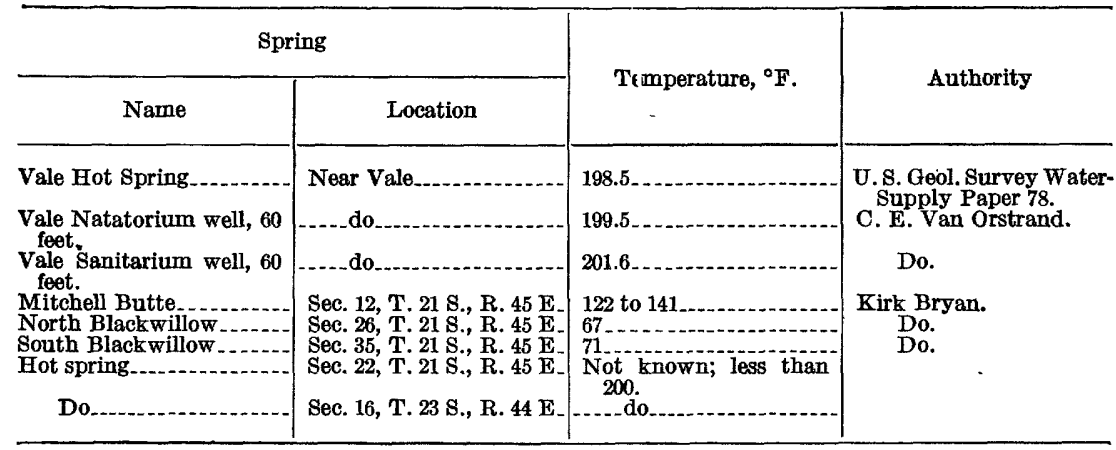

All these springs except the Blackwillow Springs are at the bottoms of deep canyons. Apparently, therefore, channels for rising hot water have been established leading to the lowest depressions, and rising hot water is not likely to be encountered in ridges between streams.

In only one deep well in the vicinity have temperature measurements been made. This well was drilled for oil by the Western Pacific Oil Co. Mr. C. E. Van Orstrand, of the United States Geological Survey, made a temperature survey and has furnished the data shown in the following table:

Temperatures in deep well in sec. 19, T. 19 S., R. 44 E., Malheur County, Oreg.

[Western Pacific Oil \& Gas Co.'s well No. 1. Measurements by C. E. Van Orstrand]

\begin{tabular}{|c|c|c|c|}
\hline $\begin{array}{l}\text { Depth } \\
\text { (feet) }\end{array}$ & $\begin{array}{c}\text { Temper- } \\
\text { ature } \\
\left({ }^{\circ} \mathrm{F} .\right)\end{array}$ & $\begin{array}{l}\text { Depth } \\
\text { (feet) }\end{array}$ & $\begin{array}{c}\text { Temper- } \\
\text { ature } \\
\left({ }^{\circ} \mathrm{F} .\right)\end{array}$ \\
\hline $\begin{array}{r}9 \\
100 \\
250 \\
500\end{array}$ & $\begin{array}{l}\text { a } 50 \\
61.2 \\
71.5 \\
84.6\end{array}$ & $\begin{array}{r}750 \\
1,000 \\
1,295\end{array}$ & $\begin{array}{r}96.9 \\
107.6 \\
115.4\end{array}$ \\
\hline
\end{tabular}

- Mean annual air temperature at Vale, Oreg.; calculated temperature of ground $59.84^{\circ}$; indicated excess earth temperature of $9.84^{\circ}$.

From these data the temperature gradient is seen to be $1^{\circ} \mathrm{F}$. for each 21.9 feet in the relatively flat country southwest of Vale. It seems likely that the ridges on both sides of the Owyhee Canyon, being exposed in the main canyon and its tributaries to loss of temperature, would probably have a smaller gradient for the first 1,500 feet.

However, this high gradient may be assumed as the worst possible condition. The maximum cover on any of the tunnels occurs near the entrance of the first tunnel of the $\mathrm{H}$ line leaving Hole in the Ground and amounts to 1,200 feet. On this assumption the maximum earth temperature that may be expected can be calculated from 
the formula $y=a+b x$, in which $x=$ depth below surface in feet; $y=$ temperature in degrees Fahrenheit at $x$ depth; $a=$ temperature in degrees Fahrenheit at a point just below the surface, as calculated by the method of least squares from the data of the table above; and $b=$ corresponding temperature gradient in degrees per foot. For the well cited $a=59.84$, and $b=0.04575$, as calculated by Mr. Van Orstrand.

The mean air temperature used in the calculations for the well is $50^{\circ}$, as observed at Vale, Oreg., at an altitude of 2,234 feet. The altitude of the high point of tunnel 1 is 3,800 feet, for which the mean annual air temperature may be assumed to be $47^{\circ}$. Therefore, at tunnel 1, $a=56.84$. Then, for point of maximum cover, $x=1,200$; $y=56.84+(0.04575 \times 1,200)=111.7^{\circ} \mathrm{F}$.

An average temperature gradient in many parts of western United States is about $1^{\circ}$ in 50 feet, or $b=0.02$. On the assumption of such a gradient for a minimum, $y=56.84+(0.02 \times 1,200)=80.8^{\circ} \mathrm{F}$.

The maximum cover of 1,200 feet exists for only a small part of the tunnel, but long stretches have a cover of 600 feet. For this cover, with the temperature gradient of the well, $y=56.84+(0.04575$ $\times 600)=86.6^{\circ} \mathrm{F}$.

A peview of the foregoing calculations, which unavoidably contain arbitrary assumptions, indicates that the maximum earth temperature to be encountered in tunnel 1 will probably not be less than $81^{\circ} \mathrm{F}$. and may be as high as $112^{\circ} \mathrm{F}$. for a short distance. Long stretches of this tunnel may have earth temperatures as high as $87^{\circ}$. The shorter tunnels with small depth will obviously not be troubled by high earth temperatures.

The possibility that hot water may be encountered seems slight, because channels of flow have already been established. A consideration of the geologic maps indicates that from each of the bodies of open and porous Owyhee basalt there is generally good opportunity for drainage, and in particular any hot water that may rise into the basalt near tunnel 1 of the $H$ line has good opportunity to escape at elevations lower than the tunnel. In the intimately faulted region south of Blackjack Butte, penetrated by tunnel 2 of the $\mathrm{H}$ line, hot water may be entrapped behind blocks of the relatively impervious Payette beds. As drilling in this area is recommended, it is likely that hot water, if any is present, will be discovered in advance of construction.

\section{MATERIALS FOR CONSTRUCTION}

The red felsite of The Box can not be quarried as dimension stone but can be obtained in rough blocks. It is hard, impervious, and brittle, will show on test a reasonable crushing strength, and is suit- 
able for rubble masonry or plums. It will crush into angular fragments suitable for concrete.

Any of the basalt ledges above the dam will yield good rock for rubble masonry or for concrete having all the qualities of good trap rock. In selecting a quarry the vesicular and scoriaceous phases of the rock should be avoided.

In The Box and more particularly just above it are bars in the river bed from which gravel can be dredged and used for concrete. The pebbles are formed mostly of volcanic rocks derived from the area upstream, and the largest are 6 inches in diameter. It seems likely, however, that there will be a deficiency in sand in this gravel.

Sand may be obtained by crushing conglomerate and pebbles from beds of the Payette formation. The nearest locality of this rock is at Coyote Butte, and there are large outcrops just south of Deer Butte and at Mitchell Butte. Certain of these gritstones and finegrained conglomerates could be quarried for use in rough ashlar masonry for the construction of buildings. The rock has a fairly good color and so far as its grain and cement are concerned should be resistant to weather. It will not, however, be easy to work, and its resistance to weather has not been demonstrated by use.

\section{LATER GEOLOGIC WORK}

After the submission of the foregoing report, studies of the Owyhee project were continued by the Bureau of Reclamation. In 1927 a large number of test holes were drilled to explore the bedrock within The Box, downstream from the area drilled in 1923 and 1924. Prof. Warren D. Smith was engaged to restudy the geology of the dam and reservoir site, and spent July 26 to August 11 in travel and field work. At the time of his study the dam site at the entrance to The Box had been abandoned, and new locations about 1,000 feet downstream and just outside the area shown on Plate 4 had been adopted. ${ }^{3 a}$ The principal conclusions and recommendations of his report are as follows:

1. While the geological conditions at this dam site are generally unsatisfactory they are not believed to be irremediable.

2. The chief concern will be in regard to the permeability of the rock formations of this site. As the quantity and duty of the water and the supply in the reservoir are so closely adjusted, large seepage would be fatal to the project.

3. Grouting on an extensive scale will have to be resorted to.

4. No large fault has been definitely loeated in the immediate vicinity of this site. However, a serious fracture normal to the axis of the proposed dam has been located passing through drill hole A-15.

5. The east abutment of the proposed dam site is much inferior to the western and will call for a great deal of stripping.

3a See sketch map in Savage, J. L., Design of the Owyhee irrigation dam : Eng. NewsRecord, vol. 100, pp. 663-667, 1928. 
6. Further drilling along the strike of the main fracture revealed by drill hole $\mathbf{A}-15$ is extremely desirable in order to ascertain its extent and the probability of movement along its plane.

A board of engineers consisting of D. C. Henny, A. J. Wiley, F. A. Banks, and W. H. Walder was convened during the period of Professor Smith's investigation and with his results before it considered the geologic aspects of the problem very fully and recommended that an additional geologic examination be made by Prof. F. L. Ransome. Professor Ransome was accordingly consulted and spent September 14 to 20 in examination of the reservoir and dam site and September 21 and 22 in drawing up a report. As this report recommended additional excavation for obtaining evidence on the existence of the fault mentioned by Professor Smith, he returned in October to inspect these excavations and filed a supplemental report dated October 27, 1927.

In his first report Ransome critically reviewed the previous reports and suggested that the special features of the felsitic rhyolite at The Box and the other rhyolite bodies correlated with it may be accounted for by intrusion of this mass into the tuffaceous conglomerate (tuff of Ransome) before complete cementation of these beds, while they were covered by the water of a shallow lake. "Some of the rhyolite probably broke through the unconsolidated tuff and spread over a part of the lake bottom as a subaqueous lava flow."

Ransome believes that if the tuffaceous beds were wet and unconsolidated and perhaps covered with water it is not difficult to account for the rapid congealing and brecciation of the outer shell of the rhyolite mass. The blunt shouldering aside of some of the tuffs without the injection of tongues or apophyses of rhyolite is also understandable. Ransome believes that deposition of the tuffaceous beds continued after the outbreak of the rhyolite and that fragments of pitchstone were locally mingled with finer material to form the fine white tuff which Bryan considered the base of the Owyhee basalt.

In regard to the more practical aspects of the problem Ransome's statement is appended with slight editorial changes: ${ }^{4}$

Features of the reservoir affecting water retention.-At the lower end of the reservoir, where the water will be deepest, the confining rock will be the prebasaltic tuff. This rock, although soft, is not exceptionally porous, and its porosity is not of a kind to permit any great permanent leakage. Contrary to the impression gained from the reports of my predecessors, the region immediately adjacent to the reservoir is not elaborately faulted, and the faults present are probably advantageous rather than objectionable. The rocks are not composed of soluble material and, being soft, are likèly to yield an impervious gouge along any fault fissure. Such gouge would prevent the movement of water along any relatively pervious bed or layer.

\footnotetext{
4 Professor Ransome desires it stated that neither of his reports was written with any
} thought of publication. 
The effect of the basaltic dikes in the prebasaltic tuff of the Hole in the Ground section of the reservoir is, I believe, negligible. The dikes are probably no more impervious than the tuff and, even if they were, could not be relied upon as constituting a continuous barrier.

Mr. Bryan raises the question of the permeability of the Columbia River basalt where this formation must be relied upon to retain the water near the mouth of Dry Creek. He disposes effectually of the possibility of leakage to the east and north but leaves unanswered the natural query as to the west and south, where the paths of escape would be down the dip of the flows. It must be admitted that there is a bare possibility of some leakage in these directions, but I can see no probability of serious losses. Examination of the basalt where bare rock is exposed in the bottoms of the ravines showed that the formation is generally hard and fairly tight. There are no visible continuous openings, and any movement of water through the rock would be slow and therefore likely to cease by the clogging of the channels. The distance that the water would have to travel to find an outlet would be many miles, with various possibilities of stoppage on the way. Finally there is a strong suggestion of some rather intricate faulting and tilting, on the lower part of Dry Creek, that would block any water that moved toward an egress in that direction. I do not consider that any considerable or permanent leakage will occur through the Columbia River basalt. Mr. Bryan's characterization of the basalt as "a rock extremely pervious to water" is, in my opinion, too sweepingly condemnatory.

The upper part of the reservoir in the Payette formation can be relied upon as practically tight. Some of the beds are very soft and weather into smooth barren slopes covered with a loose clayey soil that is evidently sticky when wet. It is inconceivable that such beds should permit the escape of any considerable quantity of water.

Although of course absolute certainty is not attainable, I consider that it is reasonably safe to conclude that the proposed reservoir, after the initial absorption, will develop no serious leakage.

Features of the dam site affecting uater retention.-The rhyolite against and on which the proposed dam will be constructed is a hard, durable rock, somewhat brittle under blows but by no means fragile. The "pitchstone agglomerate" variety, although much softer as a whole, is, as shown by drill cores and by a cut made at my suggestion, a firmer and much more impervious rock than might be expected from its weathered exposures. As this rock will probably be in contact with the dam only at one end of the structure, near its top, its relative softness is not objectionable. It is not soluble in water and is not likely to develop slipping planes under load when wet.

As exposed in the walls of the gorge at the dam site, the felsitic variety of the rhyolite, as is well brought out in the descriptions and photographs of the earlier geologic reports, is rather conspicuously fissured. A number of structures and processes have contributed to produce this general appearance of fracturing.

The first cause that contributed to the fissuring or jointing of the rhyolite (felsite) was the development of filowage lines or, more accurately, flowage surfaces in a moving viscous mass. Such surfaces give the rock a rough flssility, causing it to split more readily in one direction than in others. The surfaces of flowage run in all directions and in many places are strongly curved. In general, at the dam site the fowage surfaces are more nearly vertical than horizontal and more commonly transverse than parallel to the gorge. As the moving mass passed through increasing degrees of viscosity to the 
solid state, some of the flowage surfaces probably became actual surfaces of movement between slightly plastic blocks, giving the appearance referred to as slickensides. True slickensiding, however, such as is produced by considerable movement along faults in completely solid rock, appears to be notably absent from the mass. I did not see anywhere any material that could properly be termed "clay gouge," which is a characteristic feature of most large faults.

As the rock cooled it developed internal stresses, which found relief in numerous joints or tight fractures along which there was no appreciable slipping.

The planes of weakness, fractures or joints, developed as here suggested, have been enormously accentuated by weathering, and, although conspicuous in the cliff faces, they become tight and scarcely perceptible fractures when followed for a few feet into the cliff or may even become invisible. Short tunnels run into the cliffs at many places, usually where the rocks looked most fractured at the surface, have invariably entered rock in which the fractures are so minute and the intervening blocks so tightly keyed together as to fulfill all practical requirements as satisfactory abutment or foundation material for a high dam. Such material is generally too impervious to take any grouting.

Cracks of another kind that are conspicuous in parts of the gorge are due to the undercutting of the cliffs by the river, causing slabs or masses of rock to separate from the main mass and tilt or bulge outward toward the river, or to slip downward. The cracks shown on the left in Plate XI of Mr. Bryan's second report [pl. 9, B, in this paper] are probably of this character. Such cracks are generally more or less gaping and, if open at the top, may be filled with rubble that has fallen into them, become cemented, and take on something of the appearance of a fault breccia. The filling material, however, shows no trituration due to movement, no crushing or dragging of the fill, and no clay gouge. These features are purely superficial and will disappear when the cliff is cleaned off to provide a proper abutment for the dam.

In a few places fractures were observed of a different character from those heretofore described in this report. The best example of these fissures seen is exposed on the east side of the gorge, practically on the $D$ line of drill holes, where it coincides with a little reentrant in the cliff and with a ravine above. The fissure dips $80^{\circ}-85^{\circ} \mathrm{NW}$. and can be traced in a general N. $35^{\circ} \mathrm{E}$. direction up to a point near the 2,625-foot contour, where it appears to end against some transverse flowage structure in the rhyolite. At the river the fissure and its flling are apparently somewhat obscured by cemented debris of superficial character, and, at my suggestion, a short tunnel has been started to provide a more satisfactory exposure. Above the cliff the fissure is readily traceable by its filling of brecciated rhyolite a foot or more wide. At one place there is a zone 7 or 8 feet wide with two or three branches of the hreccia-filled fissure. The filling material is shattered and crushed felsite, cemented to a fairly hard and impervious rock. I could recognize no clay gouge and no evidence of recent or extensive movement. The fissure was not recognized on the west side of the river and may end at a feature, presently to be described, which apparently exists in the bottom of the river bed-the so-called "crevice" of the drill records.

The fissure at the $D$ line is probably the result of some settling of the rhyolite mass after its intrusion and solidification, and all movement along it has probably long since ceased. It has no particular significance as regards the proposed construction except that it is probably similar to the "crevice" and may throw some light on the character of that feature. 
The records of certain drill holes, particularly A-15, B-1, D-10, and D-11, suggest the presence of a fissure that has been followed by the river in the erosion of that part of its gorge. The testimony supplied by the drilling is somewhat vague, and the cores furnish no satisfactory clue to the nature of the material in the "crevice." The gist of the evidence appears to be that along the line indicated there is comparatively soft, broken rhyolite material that will not core and causes trouble to the drillers.

Examination of the gorge indicated that if there is a fissure coincident with the course of the river at the dam site and if, like most fissures, it has a fairly straight course, it must depart from the gorge in a little ravine on the west side, about 350 feet south of the east end of the Derrick loose-rock dam, or at coordinates S. 12,500 and W. 9,700. The topography suggested that this ravine and the saddle at its head are due to a fissure or fracture zone that is coincident with the course of the gorge above the mouth of the ravine. Examination of the surface at the head of the ravine showed the presence of brecciated material that is probably a fault breccia, and the suggestion is made that a trench be dug across the ravine, approximately on the 2,400-foot contour, with a view to exposing the bedrock and to affording an opportunity of examining the character of the fissure if one is present. Such an examination can be made at relatively slight cost and is likely to yield valuable information that could not otherwise be obtained without sinking a shaft below the river bed and drifting across the "crevice" at the dam site. Presumably the character of the fissure and its filling material, if exposed at the site of the suggested trenching, will not be greatly different from that under the dam site.

No evidence of extensive faulting could be found in the tuffs and lavas south or north of the gorge, such as would indicate the existence of a large or active fault through the gorge, and it is probable that the "crevice," like the northeast fissure at the D line, is a local zone of fracturing due to settling of the rhyolite and has long ceased to be active.

In conclusion, my opinion is that the mass of rhyolite in The Box is of such size and shape, is so situated with relation to surrounding rocks, and has such contact with them as to make any considerable or permanent leakage around, under, or through it extremely improbable. The rhyolite itself is amply strong enough to resist any stresses due to the weight or thrust of a. dam of the height proposed, if the dam is properly designed and properly keyed into the rhyolite. The stripping and excavation necessary to fulfill the last requirement is not excessive. Some local grouting may be advisable, but I do not consider that grouting on an extensive or unusual scale will be necessary.

After the exploration of the "crevice" in the gully Ransome made his second visit and in a supplemental report reached the following conclusions :

1. The fault zone uncovered in the trench is the northward continuation of the "crevice" that was encountered in drill holes A-15, B-1, D-10, and D-11 and can be considered as representative of the "crevice" material under the river.

2. The character of the striae and of the wavy grooves along the gouge seams indicates that the displacement along the fault has been of the nature of a nearly horizontal shove of one part of the rhyolite past the other part. This movement, consequently, is not due to a simple settling of the rhyolite on a yielding foundation and may have taken place at a different time from other fissures in the rhyolite. 
3. The thinness of the gouge seams and the fact that the solid rhyolite of the walls has not been smoothed and striated indicate that the movement has been moderate-probably not more than 100 feet.

4. The fact that the brittle rhyolite within the fault zone, although shattered, has not been brecciated or ground together, leads to the same conciusion as stated in paragraph 3.

5. The comparative softness of the clay gouge and the lack of cementation of the rhyolite fragments, although not conclusive, at least suggest the possibility that the fault may be younger than other fractures observed in the rhyolite and may be subject to renewed movement.

Ransome therefore recommends that in the design of the dam the presence of a fault along which renewed movement may sometime take place be given due consideration. 